4 norden 



\section{Vildledende markedsføring i markedsføringslovgivningen og på specialområderne}

Udreder: Lektor Anne-Dorte Bruun Nielsen

Aarhus Universitet

TemaNord 2006:548 
Vildledende markedsføring i markedsføringslovgivningen og på specialområderne

TemaNord 2006:548

(C) Nordisk Ministerråd, København 2006

ISBN 92-893-1367-6

Tryk: Ekspressen Tryk \& Kopicenter

Oplag: 140

Trykt på miljøvenligt papir som opfylder kravene i den nordiske miljøsvanemærkeordning.

Publikationen kan bestilles på www.norden.org/order. Flere publikationer på

www.norden.org/publikationer

Printed in Denmark

Nordisk Ministerråd

Store Strandstræde 18

1255 København K

Telefon (+45) 33960200

Fax (+45) 33960202

www.norden.org

\section{Nordisk Råd}

Store Strandstræde 18

1255 København K

Telefon (+45) 33960400

Fax (+45) 33111870

\section{Det nordiske samarbejde}

Det nordiske samarbejde er et af de ældste og mest omfattende regionale samarbejder i verden. Det omfatter Danmark, Finland, Island, Norge og Sverige samt Færøerne, Grønland og Åland. Samarbejdet styrker samhørigheden mellem de nordiske lande med respekt for de nationale forskelle og ligheder. Det øger mulighederne for at hævde Nordens interesser i omverdenen og fremme det gode naboskab.

Samarbejdet blev formaliseret i 1952 med Nordisk Råds oprettelse som forum for parlamentarikerne og regeringerne i de nordiske lande. I 1962 underskrev de nordiske lande Helsingforsaftalen, som siden har været den grundlæggende ramme for det nordiske samarbejde. I 1971 blev Nordisk Ministerråd oprettet som det formelle forum til at varetage samarbejdet mellem de nordiske regeringer og de politiske ledelser i de selvstyrende områder, Færøerne, Grønland og Åland. 


\section{Indhold}

Forord

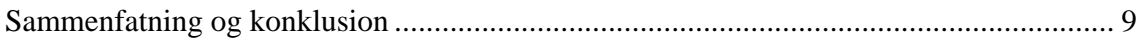

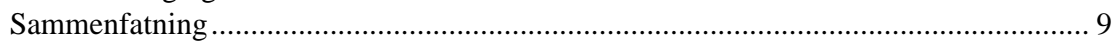

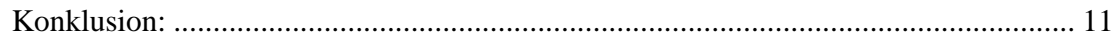

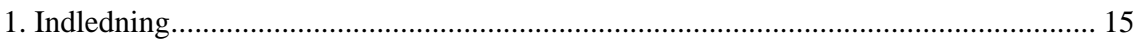

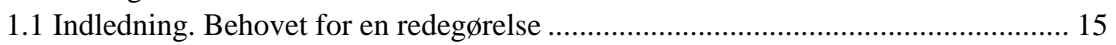

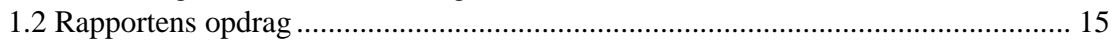

1.3 Undersøgelsens afgrænsning og systematik............................................................ 16

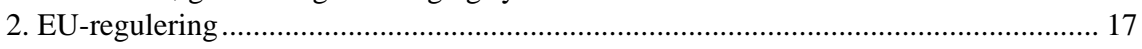

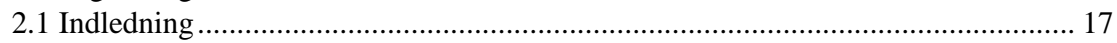

2.2 Direktiv om virksomheders urimelige handelspraksis over for forbrugerne på

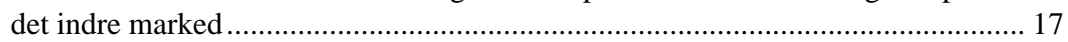

2.3 Direktiv om vildledende reklame (reklamedirektivet) ......................................... 22

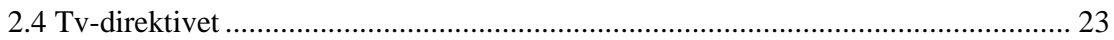

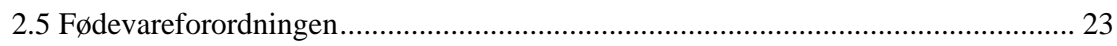

2.6 Direktiv om levnedsmiddelmærkning og reklame ............................................... 24

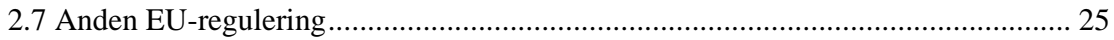

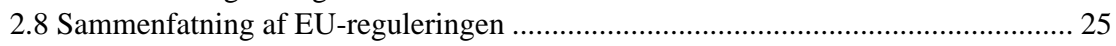

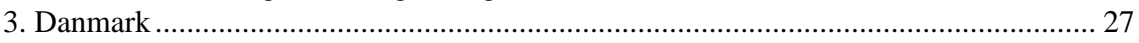

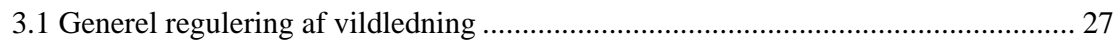

3.1.1 Markedsføringsloven og Forbrugerombudsmanden ..................................... 27

3.1.2 Praksis vedrørende overtrædelse af markedsføringslovens

vildledningsregler....................................................................................... 29

3.1.3 Konklusion vedrørende bødeniveauet i henhold til markedsføringsloven ...... 31

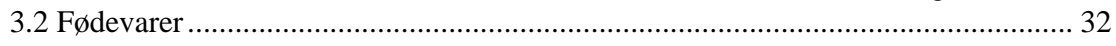

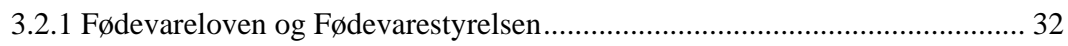

3.2.2 Praksis vedrørende fødevarelovgivningen ................................................... 35

3.2.3 Konklusion vedrørende bødeniveauet for vildledning på fødevareområdet... 37

3.3 Sundhed: Alternative behandlinger, naturmedicin, slankemidler, alkohol og

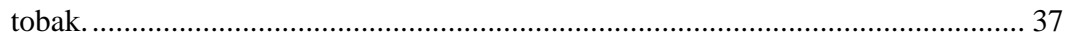

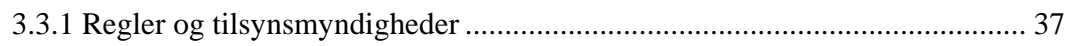

3.3.2 Praksis vedrørende overtrædelse vildledningsforbudene .............................. 38

3.3.3 Konklusion vedrørende bødeniveauet for sundhedsområdet .......................... 39

3.4 Miljø: Miljøargumenter, kemiske produkter, kosmetik.......................................... 39

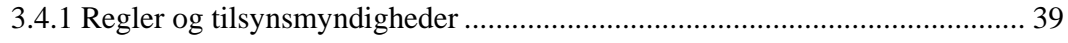

3.4.2 Praksis vedrørende miljøargumenter m.v. ................................................... 41

3.4.3 Konklusion vedrørende bødeniveauet for miljøargumenter, kemiske produkter, kosmetik m.v................................................................................. 41

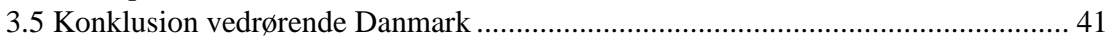

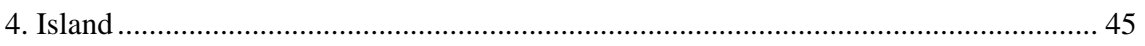

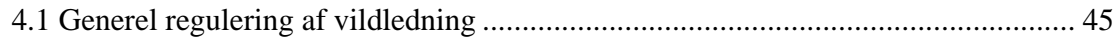

4.1.1 Lov om tilsyn med uretmæssig markedsføring m.m................................. 45

4.1.2 Praksis vedrørende lov om tilsyn med uretmæssig forretnings-føring m.m... 47

4.2 Særlovgivningen ................................................................................................ 48

4.2.1 Fødevarer, kosttilskud, naturlægemidler, alkohol og tobak ........................... 48

4.2.2 Praksis vedrørende særlovgivningen ....................................................... 50

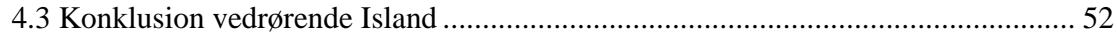

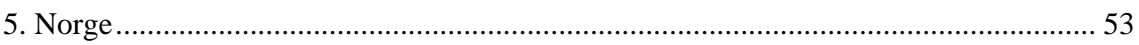

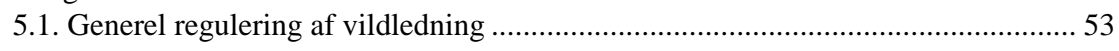

5.1.1 Markedsføringsloven og Forbrukerombudet.............................................. 53 
5.1.2 Praksis vedrørende overtrædelse af markedsføringslovens vildledningsforbud

5.1.3 Konklusion vedrørende bødeniveauet for overtrædelse af

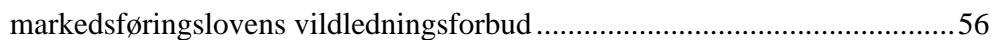

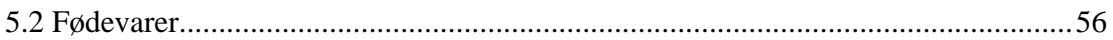

5.2.1 Matloven og Mattilsynet ................................................................................ 56

5.2.2-3 Praksis vedrørende overtrædelse af fødevarelovgivningens ......................58

5.3 Alternative behandlinger, naturmedicin, slankemidler, alkohol og tobak.................58

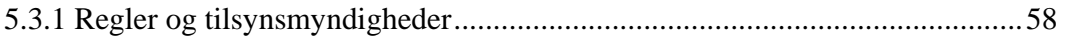

5.3.2 Praksis vedrørende overtrædelse af vildledningsforbudet .............................59

5.3.3 Konklusion vedrørende bødeniveauet for vildledning på sundhedsområdet ..60

5.4 Miljøargumenter, kemiske produkter, kosmetik m.v................................................6 60

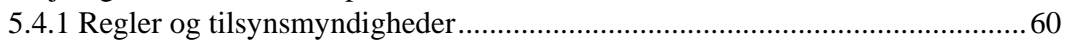

5.4.2-3 Praksis vedrørende miljøargumenter, kemiske produkter,...........................61

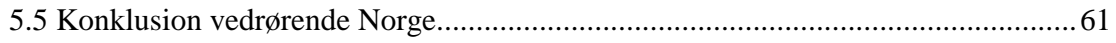

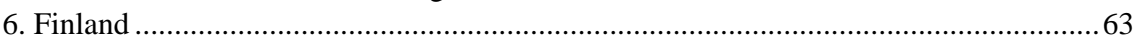

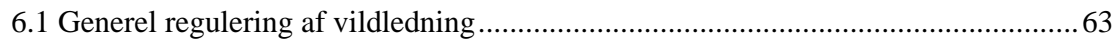

6.1.1 Konsumentskyddslagen og Konsumentombudsmanden................................63

6.1.2 Praksis vedrørende overtrædelse af Konsumentskyddslagens vildledningsregler

6.1.3 Konklusion vedrørende bødeniveauet i henhold til Konsumentskyddslagen .67

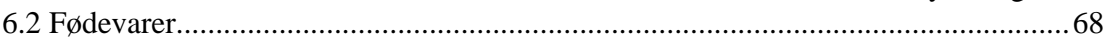

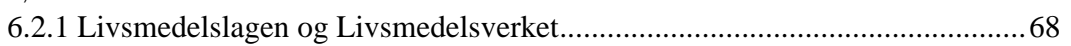

6.2.2 Praksis vedrørende fødevarelovgivningen..................................................... 69

6.2.3 Konklusion vedrørende bødeniveauet for vildledning på fødevareområdet ... 71

6.3. Alternative behandlinger, naturmedicin, slankemidler, alkohol og tobak............... 71

6.3.1 Regler og tilsynsmyndigheder .................................................................... 71

6.3.2. Praksis vedrørende overtrædelse af vildledningsforbudet ............................... 72

6.3.3 Konklusion vedrørende bødeniveauet for vildledning vedrørende

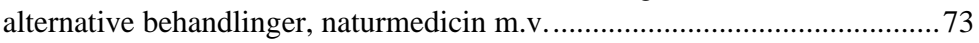

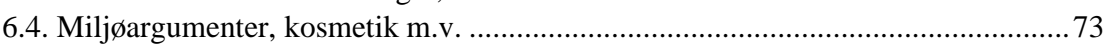

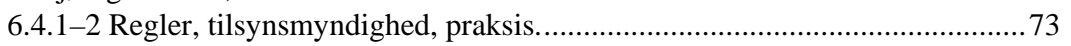

6.4.3 Konklusion vedrørende bødeniveauet for vildledende markedsføring af miljøargumenter og kosmetik .................................................................... 73

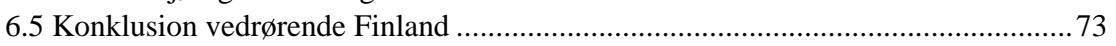

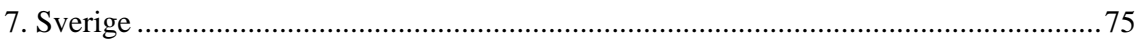

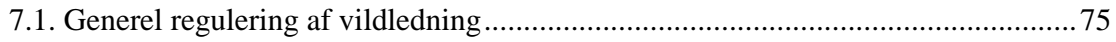

7.1.1 Markedsføringsloven og Konsumentombudsmanden ...................................... 75

7.1.2 Praksis vedrørende overtrædelse af markedsføringslovens vildledningsregler .................................................................................... 76

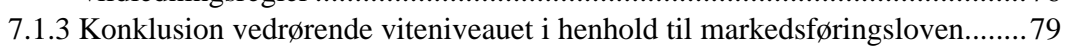

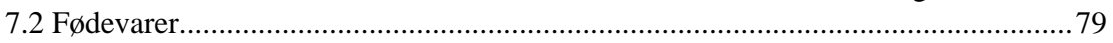

7.2.1 Livsmedelslagen, Livsmedelsverket og Konsumentverket.............................79

7.2.2-3 Praksis vedrørende fødevarelovgivningen og konklusion herpå ....................8 80

7.3 Alternative behandlinger, naturmedicin, slankemidler, alkohol og tobak...................8 81

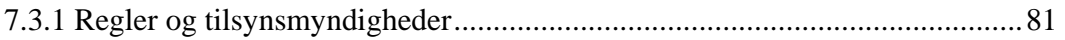

7.3.2-3 Praksis vedrørende overtrædelse af vildledningsforbudet og konklusion herpå .....

7.4 Miljøargumenter, kemiske produkter, kosmetik .................................................. 82

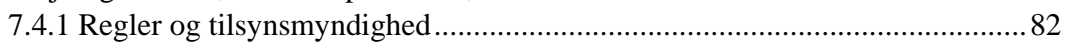

7.4.2-3 Praksis vedrørende miljøargumenter m.v. og konklusion herpå...................8 82

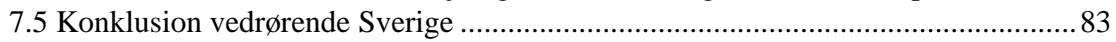

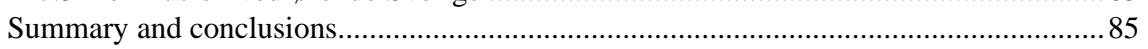

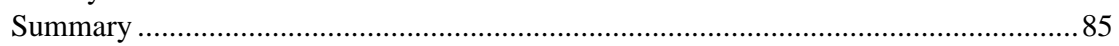

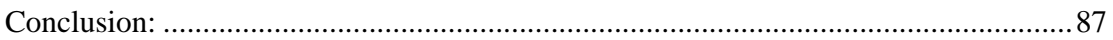




\section{Forord}

Denne rapport omhandler retsstillingen vedrørende vildledende markedsføring i medfør af den generelle regulering heraf og i medfør af særlovgivningen på udvalgte specialområder. Rapporten skal undersøge, hvorvidt forbrugeren er tilstrækkeligt beskyttet af reglerne om vildledende markedsføring og eventuelt anvise konkrete løsningsmodeller, såfremt dette ikke er tilfældet.

Rapporten er blevet til som følge af et udredningsarbejde foretaget for EK-Konsuments styringsgruppe for juridiske spørgsmål, Nordisk Ministerråd, under et projekt påbegyndt i foråret 2005 og afsluttet i foråret 2006.

Anette Høyrup, Forbrugerrådet i Danmark, har været projektleder. Den nedsatte projektgruppe bestod af Ingunn Skille Jansen / Lise Lehrmann, Barne- og familiedepartementet i Norge, Sofie Almbladh / Anne Varg / Johan Adamsson, Konsumentverket i Sverige, Anna Birna Halldórsdóttir, Neytendastofa i Island, Katri Väänänen, Konsumentverket i Finland og Camilla Udsen / Gitte Gross, Forbrugerstyrelsen i Danmark.

Lektor Anne-Dorte Bruun Nielsen, Aarhus Universitet har været udreder på rapporten.

Rapporten er opbygget således, at den indledes med en opregning af de relevante EU-retlige regler, der gælder på området. Derefter kommer en gennemgang af national ret i Danmark, Island, Norge, Finland og Sverige i nævnte rækkefølge. Der er i de enkelte lande en konklusion på forholdene omkring reguleringen af vildledende markedsføring i dette land. Sluttelig findes en samlet sammenfatning og konklusion

Denne opbygning af rapporten har betydet, at der bliver en vis gentagelse af en del af de relevante problemstillinger, hvilket skyldes, at der for en stor dels vedkommende er retsenhed på området baseret på det fælles nordiske samarbejde, men også fordi en stor del af særlovgivningens regulering er EU-regulerede regler. Det har dog været et ønske at give en sammenhængende fremstilling for de enkelte lande, således at disse afsnit i et rimeligt omfang kan læses enkeltvis, uanset at dette betyder visse gentagelser. Rapporten skal dog læses som et samlet hele for at få det fulde udbytte af den. 



\section{Sammenfatning og konklusion}

\section{Sammenfatning}

Det materielle indhold i de nordiske landes markedsføringslove og reguleringen af forbudet mod vildledende markedsføring er i meget høj grad indholdsmæssigt ens. Der er naturligvis små afvigelser fra land til land, men EU-rettens standardiserende indflydelse og den fælles nordiske baggrund og retstradition ses meget tydeligt.

Når der alligevel er nogen forskel på, hvorledes vildledningsforbudet sanktioneres i de forskellige lande, skyldes dette i højere grad, at man har grebet den praktiske indretning af tilsynet med overholdelsen forskelligt an:

I Danmark er særlovene udstyret med hver deres vildledningsforbud, og tilsynet med overholdelse heraf er spredt ud på en større mængde myndigheder, der ud fra et lex specialis synspunkt hver har deres særlige kompetence vedrørende de enkelte produkter og områder. Forbrugerombudsmanden har ganske vist det overordnede tilsyn med, at de erhvervsdrivende overholder god markedsføringsskik, men når et forhold er omfattet både af speciallovgivningen og markedsføringsloven, og der samtidig er oprettet et særligt tilsyn på området (konkurrerende tilsynskompetencer), tager Forbrugerombudsmanden normalt ikke sager op. Dette betyder, at sanktioneringen af vildledningsforbudene på særlovgivningernes områder er helt afhængig af særmyndighedernes kontrol og praksis.

Da specialmyndighederne i Danmark dels har en stor mængde forskelligartede opgaver af mere eller mindre »teknisk« art (f.eks. vedrørende sundhed og sikkerhed), dels har været underkastet ganske væsentlige indskrænkninger af deres ressourcer i de seneste år, og endelig ikke er specielt fokuserede på markedsføring, sker der tilsyneladende hos disse myndigheder en nedprioritering af tilsynet med, om markedsføringen er vildledende.

Der opstår herved en ujævnhed i tilsynet med vildledende markedsføring under markedsføringsloven og efter særlovgivningen, og dette giver sig udslag i tilsynets intensitet. Dertil kommer en historisk begrundet betydelig forskel på bødeniveauernes størrelse, der for overtrædelser af markedsføringsloven ligger på 400.000 DKK og i flere tilfælde har været på 1 og 2 mill. DKK, medens bøderne for overtrædelse af særlovgivningen ligger på »standardbøder« på omkring 10.000 DKK og med maksimumsbøder på 50.000DKK

Island har ændret sit administrative og lovmæssige system vedrørende tilsynet med markedsføring uden for særlovgivningens områder. I juli 2005 er der blevet indført en ny lov om tilsyn med uretmæssig markeds- 
føring og en ny tilsynsmyndighed, Forbrugermyndigheden, blev etableret. Forbrugermyndigheden er en ny offentlig myndighed fremkommet ved sammenlægning af den tidligere forbrugerafdeling fra Konkurrencedirektoratet og af Justervæsenet som blev nedlagt fra samme tidspunkt. Dette er sket bl.a. i erkendelse af, at det islandske tilsyn forud ikke var tilstrækkeligt effektivt og at der var behov for en bedre og mere smidig kontrol. Forbrugermyndigheden skal have tilsyn med de erhvervsdrivendes markedsføring og har også tilsyn og myndighedsopgaver omkring målsikkerhed, produktsikkerhed, el-sikkerhed, markedskontrol, legal metrologi, m.m.

Der blev samtidig oprettet et særligt uafhængigt embede som Forbrugertalsmand, som overvåger forbrugernes generelle interesser og er initiativtagende mod erhvervsdrivende og lovforvaltningen med betænkninger om forbedringer, m.m. Embedet har sit sæde og bopæl inden for Forbrugermyndighedens kontor som herudover varetager den daglige sekretariatsfunktion for embedet. Disse lovmæssige og administrative ændringer er sket for kun et år siden og endnu er det for tidligt at vurdere betydelsen af ændringerne. Det må dog bemærkes, at det bødeniveau, de er blevet i praksis lagt på Island for overtrædelse af loven om uretmæssige markedsføring (d.v.s. op til 50.000 DKK), må vurderes at være alt for lavt til at have en præventiv virkning.

Forbrugermyndigheden kan føre tilsyn med al markedsføring, men det vil fortsat i Island være således, at hvor der findes særlovgivning og dertil hørende særmyndigheder, vil tilsynet varetages af disse særmyndigheder.

I Norge er tilsynet med overholdelse af forbudet mod vildledende markedsføring lige som i Danmark delt ud på flere myndigheder, og også her bliver markedsføringen i nogen grad et forsømt område hos specialmyndighederne. Dette opvejes dog af, at Forbrugerombudsmanden og specialmyndighederne forsøger at samarbejde, således at Forbrugerombudsmanden i en periode overtager tilsynet med markedsføringen af et særligt udvalgt produkt eller en særlig markedsføringsform.

I Norge har endvidere Markedsrådets praksis vedrørende princippet om lovstridsovertrædelser medført en vis udligning af de ujævnheder, der også i norsk markedsføringsret findes vedrørende tilsynet med overholdelse af forbudet mod vildledende markedsføring. Dette lovstridsprincip medfører, at Forbrugerombudsmanden ikke kan nedprioritere et særligt område alene med den begrundelse, at det hører under særlovgivningen og dermed ikke er underlagt hans tilsyn. Hvis sagen har særlig interesse for forbrugere, vil den derfor blive taget op af forbrugerombudsmanden.

Der gives i Norge bøder i en størrelsesorden på omkring 300.000 NOK-500.000 NOK Med et tillæg af bøder på 100.000-150.000 NOK til den eller de ansvarlige personer i det markedsføringsansvarlige firma.

I Finland er en meget stor del af markedsføringen lagt under Konsumentombudsmandens tilsyn og er reguleret af Konsumentskyddslagens 2 kap. 1 §. Hvor dette ikke er tilfældet, som f.eks. vedrørende tilsynet med 
markedsføring af levnedsmidler, finder der et samarbejde sted mellem de relevante myndigheder (Konsumentverket og Livsmedelsverket), således at begge myndigheders erfaring og ekspertise bliver udnyttet, og det aftales i det enkelte tilfælde, hvilken af myndighederne, der skal tage sig af sagen. Der er derfor tilsyneladende en god konsistens i tilsynet med markedsføringen, og bødeniveauet udviser ingen forskelle uanset hvilket produkt, der er solgt ved anvendelse af vildledende markedsføring. Bødeniveauet ligger således, at der i de nyeste sager er pålagt den, der er ansvarlig for markedsføringen bøder på op til 50.000 euro (300.000 FIM),

Sverige har ikke problemer svarende til de danske med at koordinere indsatsen over for vildledende markedsføring i relation til forskellige produkter, da al markedsføringstilsyn er underlagt Konsumentombudsmanden, hvorfor tilsynets intensitet og straffenes størrelse vil blive ensartet på hele området.

Bødernes størrelse er i høj grad »standardiserende«, og der ses ikke forskel på hvilket produkt, der er markedsført på en retsstridig måde. Bødestørrelsen ligger i nyere praksis omkring 400.000 SEK med afvigelser i konkrete tilfælde. Der ses en tendens til opadgående bødestørrelse ved særligt grove tilfælde af vildledning, hvilket er gavnligt, og det må bemærkes, at bødestørrelsen ikke bør stagnere, såfremt markedsføringsudgifterne og de tilsigtede fortjenester stiger.

\section{Konklusion:}

Den enkleste og tilsyneladende mest effektive organisering af tilsynet med overholdelse af forbudet mod vildledning findes formodentlig i de svenske og finske modeller:

Konsumentverket og Forbrugerombudsmanden har som ovenfor nævnt i Sverige tilsyn generelt på samtlige områder, som denne rapport omfatter. De øvrige myndigheder, der har tilsyn med forhandling og markedsføring af specielle produkter, skal ikke føre tilsyn med, om en markedsføring er utilbørlig, uvederhæftig eller vildledende og i strid med markedsføringslovens regler om god markedsføringsskik i lovens $\S 4$ og vildledningsforbudet i § 6., og en meget stor del af markedsføringen er i Finland lagt under Konsumentombudsmandens tilsyn og er reguleret af Konsumentskyddslagens 2 kap. $1 \S$. Hvor dette ikke er tilfældet, som for eksempel vedrørende tilsynet med markedsføring af levnedsmidler, finder der et samarbejde sted mellem de relevante myndigheder (Konsumentverket og Livsmedelsverket), således at begge myndigheders erfaring og ekspertise bliver udnyttet, og det aftales i det enkelte tilfælde, hvilken af myndighederne, der skal tage sig af sagen.

Dette giver en meget høj grad af konsistens i disse landes sanktionering af forbudet mod vildledende markedsføring, og der er ingen forskel på bødeniveauet for forskellige typer af varer. 
Som det vil fremgå af ovenstående, er behovet for ændringer af lovgivning og/eller praksis vedrørende håndhævelse af forbudet mod vildledning i forbindelse med markedsføring forskelligt i de forskellige lande.

Størst er behovet for ændringer på området tilsyneladende i Danmark, hvor man kunne overveje enten at ændre lovgivningen, således at tilsynet med al markedsføring bliver overført til Forbrugerombudsmanden med de fordele og ulemper, dette vil have, eller tage initiativer til, at de relevante myndigheder (i højere grad end det måtte være tilfældet i dag) samarbejder vedrørende håndhævelsen af forbudet imod vildledning i særlovgivningen. Dette gælder både tilsynets intensitet og niveauet for bødernes størrelse. Der er dog forskel på, hvorledes tilsynet med markedsføringen er foretaget inden for de enkelte dele af særlovgivningen, idet fødevarestyrelsen allerede nu har oprettet en kontrolenhed på kosttilskudsområdet, og fødevareregionerne i perioder har foretaget kampagner for at kontrollere omfanget af vildledning inden for forskellige områder med gode resultater til følge.

Det vurderes, at der i Danmark hverken er brug for flere retsregler eller flere tilsynsmyndigheder, men at der er behov for en samling og koordinering af indsatsen på området. Der er endvidere behov for, at der tilføres de relevante tilsynsmyndigheder tilstrækkelige ressourcer til varetagelsen af disse opgaver, da en regulering af et område uden reelle kontrolmuligheder ikke kan forventes at fungere efter hensigten. Det må hertil bemærkes, at overtrædelsesmulighederne er i stærkt stigende vækst som følge af nye markedsførings- og salgsformer på et marked i hastig udvikling, herunder bl.a. udviklingen omkring Internettet.

I Norge har man lovmæssigt forhold, der i høj grad ligner de danske, med særlovgivning og myndigheder i konkurrerende kompetence, og tilsynet på specialområderne er i forhold til markedsføringsloven mindre intensivt - måske næsten ikke-eksisterende. Disse forhold er dog i nogen grad forsøgt afbødet ved indgåelse af aftaler om samarbejde mellem Forbrugerombudsmanden og specialmyndighederne, således at Forbrugerombudsmanden inden for konkrete områder overtager tilsynet for en periode. Markedsrådets praksis har endvidere betydet, at Forbrugerombudsmanden tager sager op, som principielt hører under særlovgivningen, men som også er en krænkelse af den markedsretlige generalklausul.

I Finland er store dele af tilsynet med de områder, der i denne rapport er defineret som specialområder, lagt direkte under Konsumentombudsmandens tilsyn, hvilket forenkler problemstillingen en del. Der er derud over et aktivt samarbejde mellem de relevante myndigheder, hvilket betyder, at der ikke opstår skævheder hverken i tilsynet eller bødeniveauet.

Sverige har ikke problemer svarende til de danske med at koordinere indsatsen over for vildledende markedsføring i relation til forskellige produkter, da al markedsføringstilsyn er underlagt Konsumentombudsmanden, hvorfor tilsynets intensitet og straffenes størrelse vil blive ensartet på hele området. 
Island har et administrativt system, hvor myndigheder under de enkelte kommuner, fører tilsynet med markedsføringen på specialområderne. Hvor der findes overtrædelser, skal de kommunale myndigheder anmode anklagemyndigheden om at anlægge straffesag. Dette system er meget tungt og ressourcekrævende. Det generelle tilsyn med markedsføringen er ændret pr. 1. juli 2005, hvorefter der er oprettet en Forbrugermyndighed, der skal føre tilsyn med markedsføringen. Hos den nye Forbrugermyndighed findes kun nogle beslutninger på grund af lov om tilsyn med uretmæssig markedsføring, da denne nye myndighed er meget nylig oprettet, men de materielle regler er i vid udstrækning de samme i den nye markedsføringslov som i den gamle konkurrencelov. Praksis efter den tidligere lovgivning udgøres af ret få administrative sager og kun en enkelt dom, men det billede, der viser sig vedrørende bødeniveauet er, at der gives ret små bøder (i størrelsesordenen mellem 20-50.000 DKK), hvilket næppe kan have nogen præventiv effekt i sig selv. 



\section{Indledning}

\subsection{Indledning. Behovet for en redegørelse}

Den nordiske markedsføringslovgivning indeholder en række regler, som regulerer forbud mod vildledende markedsføring. Dette gælder både den generelle regulering i de danske. norske og svenske markedsføringslove, i den finske Konsumentskyddslag og i den nye islandske Lov om tilsyn med uretmæssig forretningsskik, og det gælder en række særlove.

Der ses ikke at foreligge et samlet overblik over lovgivning og praksis vedrørende vildledende reklame, ligesom der ikke er foretaget nogen sammenlignende undersøgelse af bødeniveauet, hverken landene imellem eller myndighederne imellem i de enkelte lande. Denne sammenligning og oversigt er hermed søgt udført med ganske overraskende resultater til følge, jf. kapitel 8

\subsection{Rapportens opdrag}

Målsætningen for dette projekt er, at rapporten skal undersøge, hvorvidt forbrugerne er tilstrækkeligt beskyttet af reglerne om vildledende markedsføring på specialområderne samt anvise konkrete løsningsmodeller, såfremt dette ikke er tilfældet.

Rapporten skal foretage en komparativ analyse af regler og praksis i de nordiske lande vedrørende vildledende markedsføring inden for fødevare-, miljø- og sundhedslovgivningen samt drage paralleller til den generelle markedsføringslov. Endvidere skal det praktiske samspil mellem general- og speciallovgivningen vurderes, og det skal undersøges, hvorvidt tilsyn, kontrol og klageadgang er effektiv i relation til vildledende markedsføring på specialområderne.

Projektbeskrivelsen kan sammenfattende formuleres således:

Forbudet mod vildledende reklame er begrundet i væsentlige hensyn til forbrugerne. Når erhvervsdrivende afgiver misvisende oplysninger i forbindelse med markedsføring af et produkt, bliver købesituationen uigennemsigtig, og muligheden for at foretage et fornuftigt forbrugsvalg forhindres. Ofte vil vildledende markedsføring være til økonomisk gene for forbrugeren, da vildledningen resulterer i unødvendige køb. Den vildledende markedsføring kan tilmed være direkte skadelig for forbrugeren, eksempelvis når fedtholdige produkter markedsføres som et naturligt og grønnere produkt eller farlige produkter markedsføres som uskadelige.

Nutidens intense markedsføring af produkter stiller til stadighed spørgsmålstegn ved forbrugerbeskyttelsens tilstrækkelighed. Markedsføringslovgivningen med dens generelle og specielle forbudsregler sikrer et vist minimum af beskyttel- 
se og supplerer speciallovgivningen, hvis indhold afhænger af områdets særlige karakter. Bestemmelserne om vildledning, tilsyn og sanktioner heraf er forskellige afhængig af, om det er fødevarer, kosmetik, kemikalier eller andre forbrugerprodukter, der markedsføres med sundheds- eller miljømæssige egenskaber.

Samspillet mellem general- og speciallovgivningen ikke ganske klar i praksis, hvilket kan medføre en uens beskyttelse af forbrugeren Rapporten skal undersøge, om denne vekslende forbrugerbeskyttelse begrundet i specialområdernes karakter er tilstrækkelig set ud fra et forbrugerperspektiv samt anvise konkrete løsningsmodeller til sikring af bedre vilkår. Løsningsmodellerne skal være af juridisk karakter som f.eks. konkrete forslag til lovregulering og således ikke lægge op til praktiske tiltag som mærkningsordninger eller lignende.

\subsection{Undersøgelsens afgrænsning og systematik}

Indledningsvist opregnes den relevante EU-regulering med henblik på at give et overblik over, hvor den nordiske lovgivning hviler på retsligt forpligtende EU direktiver og forordninger. Der opregnes her alene de mest centrale dele af de på visse områder talrige specialreguleringer. Der er endvidere kun medtaget nationale og fællesskabsretlige regler, der forbyder vildledning. Der findes på alle retlige niveauer talrige regler om oplysningspligt, men disse er ikke inddraget af pladsmæssige og systematiske grunde, om end fortielse af en relevant oplysning kan have særdeles vildledende effekt. Den form for vildledning, der kan forekomme i form af sammenlignende reklame er kun meget sporadisk berørt, idet dette repræsenterer en lille niche af vildledningsproblematikken, og primært har et konkurrenceretligt fokus.

Derefter gennemgås det enkelte nordiske land hver for sig, hvor der først redegøres for den generelle markedsføringslovgivning og vildledningsforbudene heri, hvorefter der gennemgås en udvalgt del af speciallovgivningen. Der er her lagt særligt fokus på levnedsmiddellovgivningen, hvorefter sundhedsområdet er repræsenteret i form af reguleringen af alternative behandlinger, kosttilskud og slanke-produkter samt alkoholog tobakslovgivningen. Miljøargumenter i markedsføringen, kemiske produkter og kosmetik er udvalgt inden for miljøområdet.

Efter en gennemgang af disse regelsæt foretages en sammenlignende analyse af de generelle og de specielle regler, der regulerer vildledning i markedsføringen, hvorefter der endelig foretages en konklusion vedrørende det enkelte lands retslige regulering og af bødeniveauet for sanktioneringen heraf.

Som sidste kapitel findes en sammenfatning af rapporten og en samlet konklusion på den samlede komparative analyse og der stilles forslag til ændringer i regler eller praksis i de enkelte lande. 


\section{EU-regulering}

\subsection{Indledning}

Vildledende reklame har været imellem de første områder, hvor EU har foretaget retlig regulering af uacceptabel kommerciel adfærd. Dette skete allerede i 1984 ved direktiv om vildledende reklame (dir. 84/450/EC), som var et minimumsdirektiv, der skulle lægge en fælles »bund « i reguleringen af reklamen. Reglerne om vildledning og vildledende forretningsmetoder er siden blevet suppleret og udvidet væsentligt ved bl.a. direktiv om vildledende og sammenlignende reklame (dir. 97/55/EC, der ændrer dir. 84/450/EC), direktivet om TV uden grænser (dir. 89/552/EEC), som senere ændret ved tv-direktivet (dir. 97/36/EC). Hertil kommer bestemmelser i specialdirektiver, jf. nedenfor afsnit 2.7.

Vildledningsproblematikkens modstykke - oplysningspligten - er reguleret ved et stort antal direktiver, hvoraf bl.a. kan nævnes direktiverne om kreditkøb, dørsalg, fjernsalg, e-handel, pakkerejser, timeshare m.fl., men her skal som nævnt i afsnit 1.3 kun fremdrages regler, der specifikt forbyder vildledning, ligesom primært regler vedrørende generel markedsføring medtages. Hertil kommer dog enkelte direktiver vedrørende udvalgte områder inden for fødevarer, miljø og sundhed.

Den seneste regulering af vildledning findes i direktivforslaget om virksomheders urimelige handelspraksis over for forbrugerne på det indre marked, der ventes vedtaget inden for en overskuelig tidsramme. Dette direktiv medfører, at manglende overholdelse af direktivbestemt oplysningspligt anses som vildledende markedsadfærd. Se nærmere herom nedenfor, afsnit 2.2 .

\subsection{Direktiv om virksomheders urimelige handelspraksis over for forbrugerne på det indre marked}

Indførelsen af et afsenderlandsprincip i direktivet om elektronisk handel (dir. 2000/31/EF) foranledigede, at der i december 1999 blev vedtaget en erklæring, hvori Kommissionen og medlemsstaterne anerkendte, at der er behov for yderligere initiativer vedrørende regulering af virksomheders markedsadfærd i forhold til forbrugerne. Afsenderlandsprincippet medfører, at en erhvervsdrivende, der foretager markedsføring over Internettet eller via andre grænseoverskridende elektroniske medier, alene skal overholde sit etableringslands regler herom, uanset om markedsføringen er rettet mod forbrugerne i et andet land. Da reguleringen af markedsfø- 
ringsretlige forhold i EU-retten har været forholdsvist beskeden og kun regulerende enkeltområder eller enkelte markedsføringsmetoder, vil forskellen i medlemsstaternes regulering derfor kunne betyde, at de europæiske virksomheder ikke er underlagt ens konkurrencevilkår. Ligeledes kan forbrugerbeskyttelsen blive forringet i det omfang, der er forskelle i medlemsstaternes beskyttelsesniveau.

Resultatet af denne erklæring er udmøntet i direktivforslag om virksomheders urimelige handelspraksis over for forbrugerne på det indre marked.

Direktivet har til formål at harmonisere medlemsstaternes regulering af urimelig handelspraksis i forholdet mellem erhvervsdrivende og forbrugerne, og angår alene den form for urimelig handelspraksis, der kan skade forbrugernes økonomiske interesser. Dette medfører, at erhvervsmæssig adfærd, der f.eks. krænker anstændighed, social ansvarlighed eller andre almene samfundsinteresser, ikke er omfattet af direktivet, når disse ikke er egnet til at påvirke efterspørgslen, men alene til at krænke hele eller dele af befolkningen. Eksempler på sådan adfærd kunne være race- eller kønsdiskriminerende udsagn uden effekt på efterspørgslen.

Sundheds- og sikkerhedsaspekter, der relaterer sig til produktet, falder desuden uden for forslagets anvendelsesområde, hvorfor regler, der omhandler reklame for alkohol, tobak og lægemidler, ikke er omfattet, såfremt disse regler er fastsat ud fra et sundhedshensyn.

Sektorregulering, der baseres på EU-regulering og regulerer urimelig handelspraksis specifikt, har forrang i forhold til forslaget, medmindre sektorreguleringen alene bygger på bredere principper om rimelig handelspraksis m.v. Direktivet om urimelig handelspraksis har forrang i forhold til nationale regler, der er indført på baggrund af minimumsdirektiver, og som er mere restriktive end de regler, der følger af disse direktiver og direktivet om urimelig handelspraksis.

Direktivet bygger på en generalklausul, der indeholder et forbud mod urimelig handelspraksis. Ved urimelig handelspraksis forstås praksis, der ikke opfylder kravene til professionel omhu, og som er egnet til at påvirke efterspørgslen, hvilket forstås, som at kunne påvirke en gennemsnitsforbrugers økonomiske adfærd.

Urimelig handelspraksis er navnlig markedsføring, der er aggressiv eller vildledende. Vildledende markedsføring dækker både vildledende handlinger (f.eks. oplysninger om salgsformen som sådan, produktets art, egenskaber, anvendelse, pris, oprindelsesland, den erhvervsdrivendes identitet eller kvalifikationer m.v.) og vildledende udeladelser, hvilket vil sige undladelse af f.eks. at oplyse om produktets farlighed, begrænsninger, om relevante forhold hos den erhvervsdrivende, prisen eller andet, som ville have været af betydning for gennemsnitsforbrugeren.

Oplysninger, der bevidst overdriver eller anvender udtalelser, som ikke skal tages alvorligt, samt undladelse af at oplyse om noget, som gen- 
nemsnitsforbrugerne må formodes at kende, skal ikke anses som urimelig eller vildledende handelspraksis.

Manglende overholdelse af informationskrav - herunder den nye forordning om salgsfremmende foranstaltninger - der følger af anden EUregulering, vil blive betragtet som vildledende reklame.

Implementering af direktivet vil formentlig kræve en ændring i de nordiske landes markedsføringsregler vedrørende god markedsføringsskik og vildledende markedsføring. De generelle regler i de nordiske lande bliver i vidt omfang udfyldt ved domspraksis, bekendtgørelser, retningslinjer, vejledninger, nationale og internationale handelskodeks, og både for at sikre den korrekte implementering og for at udforme en klar og overskuelig retstilstand for forbrugerne og de erhvervsdrivende vil de gældende regler skulle revideres. Dette arbejde er allerede i gang i flere af de nordiske lande.

Forslaget er suppleret med en liste over eksempler på urimelig handelspraksis og en ikke-udtømmende liste over informationskrav i eksisterende direktiver.

Formålet med direktivet er at bidrage til et velfungerende indre marked og fjerne de lovmæssige hindringer herfor, der er kommet i og med, at de nationale regler, der bl.a. implementerer reklamedirektivet, er på meget forskellige forbrugerbeskyttelsesniveauer. (Reklamedirektivet er et minimumsdirektiv og er ikke til hinder for, at de enkelte medlemsstater har opretholdt eller vedtaget foranstaltninger, som sikrer en mere vidtgående forbrugerbeskyttelse, hvorfor medlemsstaternes bestemmelser om vildledende reklame varierer betydeligt).

Direktiv om urimelig handelspraksis artikel 6 og 7 indeholder regler om vildledende handlinger og udeladelser.

\section{VILDLEDENDE HANDELSPRAKSIS}

$\underline{\text { Artikel } 6}$

Vildledende handlinger

1. En handelspraksis betragtes som vildledende, hvis den indeholder urigtige oplysninger og derfor er usandfærdig eller f.eks. i kraft af sin generelle fremstillingsform vildleder eller kan forventes at vildlede en gennemsnitsforbruger, selv om oplysningerne er faktuelt korrekte, med hensyn til et eller flere af følgende elementer og under alle omstændigheder foranlediger eller kan forventes at foranledige ham til at træffe en transaktionsbeslutning, som han ellers ikke ville have truffet:

a) produktets eksistens eller art

b) de væsentligste egenskaber ved produktet, såsom det omfang, i hvilket det står til rådighed, dets fordele, risici, udførelse, sammensætning, tilbehør, eftersalgsservice og klagebehandling, måden og tidspunktet for fremstilling eller ydelse, leve- 
ring, dets hensigtsmæssighed, anvendelse, mængde, specifikationer, geografiske eller handelsmæssige oprindelse eller de resultater, som kan forventes opnået ved brugen, eller resultaterne af og de vigtigste karakteristika ved afprøvning eller kontrol af produktet

c) omfanget af den erhvervsdrivendes forpligtelser, begrundelsen for den pågældende handelspraksis og arten af salgsprocessen, enhver erklæring eller ethvert symbol i forbindelse med direkte eller indirekte støtte eller godkendelse af den erhvervsdrivende eller produktet

d) prisen eller den måde, hvorpå prisen beregnes, eller en særlig prismæssig fordel

e) behov for eftersyn, reservedele, udskiftninger eller reparationer

f) forhold, der vedrører den erhvervsdrivendes eller dennes agents egenskaber og rettigheder, såsom hans identitet og formue, hans kvalifikationer, status, godkendelse, tilhørsforhold eller tilknytning og immaterielle rettigheder eller de ham tilkendte prisbelønninger og udmærkelser.

g) forbrugerens rettigheder eller de risici, som han eventuelt løber.

2. En handelspraksis betragtes også som vildledende, når den i sin faktuelle sammenhæng, idet der tages hensyn til alle elementer og betingelser, foranlediger gennemsnitsforbrugeren eller kan forventes at foranledige denne til at træffe en transaktionsbeslutning, som han ellers ikke ville have truffet, og den indebærer:

a) en markedsføring, herunder sammenlignende reklame, vedrørende et produkt, som medfører, at det forveksles med et produkt, et varemærke, en handelsbetegnelse eller andre kendetegn, som tilhører en konkurrent.

b) at den erhvervsdrivende ikke overholder bestemmelserne i adfærdskodekser, som han har forpligtet sig til at overholde, i de tilfælde hvor

i) der er tale om et fast tilsagn, som kan verificeres, og ikke om en forhåbning, og hvor

ii) den erhvervsdrivende i en handelspraksis angiver, at han er bundet af kodeksen.

\section{Vildledende udeladelser er reguleret i artikel 7:}

Artikel 7

Vildledende udeladelser

1. En handelspraksis betragtes som vildledende, hvis den i sin faktuelle sammenhæng, idet der tages hensyn til alle elementer og forhold og begrænsningerne ved kommunikationsmediet, udelader væsentlige oplysninger, som gennemsnitsforbrugeren har behov for i den pågældende situation for at træffe en informeret transaktionsbeslutning, og derved foranlediger gennemsnitsforbrugeren eller kan forventes at foranledige denne til at træffe en transaktionsbeslutning, som han ellers ikke ville have truffet. 
2. Det betragtes også som en vildledende udeladelse, hvis en erhvervsdrivende skjuler eller på en uklar, uforståelig, dobbelttydig eller uhensigtsmæssig måde præsenterer væsentlige oplysninger, jf. stk. 1, eller ikke angiver den kommercielle hensigt med den pågældende handelspraksis, hvis den ikke allerede fremgår tydeligt af sammenhængen.

3. Når det medie, der anvendes til at formidle denne handelspraksis, indebærer begrænsninger i rum eller tid, skal der tages hensyn til disse begrænsninger og til foranstaltninger, som den erhvervsdrivende har truffet for at gøre oplysningerne tilgængelige for forbrugerne på anden måde, når det afgøres, om oplysninger er blevet udeladt.

4. Ved en opfordring til køb betragtes følgende oplysninger som væsentlige, hvis de ikke allerede fremgår tydeligt af sammenhængen:

a) produktets vigtigste karakteristika i et omfang, der svarer til mediet og produktet

b) den erhvervsdrivendes fysiske adresse og navn, som f.eks. hans firmanavn og, hvor det er relevant, den fysiske adresse og navnet på den erhvervsdrivende, på hvis vegne han handler

c) prisen inklusive afgifter, eller, hvis produktets art gør, at prisen ikke med rimelighed kan udregnes på forhånd, den måde, hvorpå prisen udregnes, samt, hvor det er relevant, alle yderligere omkostninger vedrørende fragt, levering eller porto eller, hvor sådanne omkostninger ikke med rimelighed kan udregnes på forhånd, oplysninger om, at der kan forekomme sådanne yderligere omkostninger

d) forhold vedrørende betaling, levering, gennemførelse og klagebehandlingspolitik, hvis disse afviger fra kravene i forbindelse med erhvervsmæssig diligenspligt

e) ved produkter og transaktioner, der omfatter fortrydelsesret eller annulleringsret, eksistensen af en sådan ret.

5. Oplysningskrav, som er fastlagt i fællesskabslovgivningen i forbindelse med kommerciel kommunikation, herunder reklame eller markedsføring, og som er anført i en ikke-udtømmende fortegnelse i bilag II, betragtes som væsentlige.

Direktivforslaget indeholder herudover i artikel 14 en række ændringer i reklamedirektivet, bl.a. vedrørende sammenlignende reklame, der ikke må være vildledende, hverken i henhold til reklamedirektivets regler eller direktivet om virksomheders urimelige handelspraksis over for forbrugerne.

Direktivforslagets bilag 1 indeholder som ovenfor nævnt en liste over former for handelspraksis, som under alle omstændigheder anses som urimelige.

Direktivets bilag II indeholder en opregning af de fællesskabsretlige bestemmelser vedrørende reklame og kommerciel kommunikation, som det vil være at anse som vildledende markedsføring at undlade at opfylde. Disse direktivbestemmelser vedrører oplysningspligten og findes bl.a. i direktiv om pakkerejser (R dir. 90/314/EØF), direktiv om elektronisk handel (EP og R dir. 2000/31/EF), direktiv om forbrugerkredit m.fl. 


\subsection{Direktiv om vildledende reklame (reklamedirektivet)}

Rådets direktiv af 10 . september 1984 om vildledende og sammenlignende reklame (84/450), som ændret ved EP/R dir. 97/55, ændres ved direktivet om urimelig handelspraksis og får herefter som formål at beskytte de erhvervsdrivende mod vildledende reklame og urimelige følger heraf, jf. artikel 1.

Ved vildledende reklame forstås enhver reklame, der på nogen måde, herunder dens udformning, skaber eller er egnet til at skabe et urigtigt indtryk hos de personer, den er rettet til eller når ud til, og som på grund af dens vildledende karakter kan antages at påvirke deres økonomiske adfærd, eller som af disse grunde skader eller er egnet til at skade en konkurrent (artikel 2, stk. 2).

Ved afgørelsen af, hvorvidt en reklame er vildledende, skal der tages hensyn til alle dens bestanddele, og især til oplysninger vedrørende:

a) Egenskaberne ved varerne eller tjenesteydelserne, såsom det omfang, i hvilket de står til rådighed, deres beskaffenhed, udførelse og sammensætning, måden og tidspunktet for fremstilling eller ydelse, deres hensigtsmæssighed, anvendelsesmuligheder, mængde, specifikationer, geografiske eller handelsmæssige oprindelse eller de resultater, som forventes opnået ved brugen eller resultaterne af og de vigtigste karakteristika ved afprøvning eller kontrol af varerne eller tjenesteydelserne,

b) prisen eller den måde, hvorpå prisen beregnes samt betingelserne for levering af varerne og erlæggelse af tjenesteydelserne.

c) annoncørens status, egenskaber og rettigheder, såsom hans identitet og formue, hans kvalifikationer og immaterielle rettigheder eller de af ham tilkendte prisbelønninger og udmærkelser.

Sammenlignende reklame må ikke være vildledende, jf. artikel 3 A, stk. 1 a.

Medlemsstaterne skal i medfør af artikel 4 påse, at der findes tilstrækkelige og effektive midler til bekæmpelse af vildledende reklame. Medlemsstaterne skal således tillægge domstolene eller de administrative myndigheder beføjelser til om nødvendigt at udstede påbud om ophør med vildledende reklame eller at forbyde en sådan reklames offentliggørelse.

Endvidere kan medlemsstaterne tillægge domstolene eller de administrative myndigheder beføjelser til at kræve afgørelser offentliggjort, jf. artikel 4.

Direktivet bestemmer yderligere, at medlemsstaterne skal tillægge domstolene eller de administrative myndigheder ret til at kræve, at en annoncør, hvis dette er hensigtsmæssigt, kan fremlægge beviser for rigtigheden af de faktiske forhold, der gøres gældende i reklamen. Direktivet er et minimumsdirektiv og er ikke til hinder for, at medlemsstaterne 
opretholder eller vedtager bestemmelser for vildledende reklame med henblik på at sikre en mere vidtgående beskyttelse af forbrugeren, erhvervsdrivende samt af offentligheden i almindelighed. (Reguleringen af sammenlignende reklame er dog en maksimumsregulering).

Da direktivet efter indførelsen af direktiv om urimelig handelspraksis fremtidigt alene skal regulere de erhvervsdrivendes forhold, vil tidligere praksis efter direktivet alene kunne anvendes som en vejledning i fortolkning og anvendelse af vildledningsreglen i forhold til forbrugeren, men da direktiv om urimelig handelspraksis tilstræber en øget forbrugerbeskyttelse i forhold til tidligere, må det hidtidige niveau fortsat gælde som en minimumsstandard.

\subsection{Tv-direktivet}

Direktiv om udøvelse af tv-radiospredningsvirksomhed (R dir. 89/552, som ændret ved EP/R dir. 97/36) tager ikke direkte stilling til vildledende reklame, men kapitel IV regulerer fjernsynsreklamer, sponsorvirksomhed og teleshopping.

Fjernsynsreklamer og teleshopping skal klart kunne identificeres som sådanne og skal holdes klart adskilt fra det øvrige program, og skjult reklame og subliminale teknikker er forbudt, jf. artikel 10. Denne regel medfører, at det ikke er nødvendigt at definere skjult reklame og subliminale teknikker som vildledende for at kunne skride ind over for sådanne reklamer, idet disse reklameformer er umiddelbart reguleret i direktivet.

\subsection{Fødevareforordningen}

Fødevareforordningen, Europa-Parlamentets og Rådets forordning af 28. januar 2002 om generelle principper og krav i fødevarelovgivningen om oprettelse af Den Europæiske Fødevaresikkerhedsautoritet og om procedurer vedrørende fødevaresikkerhed (EF nr. 178/2002) har til formål at sikre et højt niveau for beskyttelsen af menneskers sundhed og af forbrugernes interesser i relation til fødevarer.

Forordningen indeholder i kapitel II om den generelle fødevarelovgivning en Afdeling 4 med generelle krav til fødevarelovgivningen. Blandt disse generelle krav er artikel 16 vedrørende præsentation af fødevarer.

Reklamer for fødevarer, mærkningen og præsentationen af fødevarer, herunder deres form, fremtræden eller indpakning, de anvendte indpakningsmaterialer, den måde, hvorpå varerne er arrangeret, og de angivelser, hvori de udstilles, samt de informationer, der uanset form og medium gives, må ikke vildlede forbrugerne. 
Denne regel er en af hjørnestenene i den EU-retlige regulering af markedsføring af fødevarer i EU, og den gælder umiddelbart i alle EU-lande

Fødevareforordningens artikel 16 berører ikke specifikke bestemmelser i fødevarelovgivningen i øvrigt, hverken på nationalt plan eller i fællesskabsretten, jf. artikel 16, jf. artikel 2.

De generelle krav til fødevarelovgivningen og dermed også artikel 16 vedrører alle led i produktionen, tilvirkningen og distributionen af fødevarer.

\subsection{Direktiv om levnedsmiddelmærkning og reklame}

Direktiv om levnedsmiddelmærkning og reklame (dir. 2000/13/EF) vedrører mærkning af levnedsmidler, der er bestemt til i uforandret stand at leveres til den endelige forbruger, samt visse aspekter i forbindelse med præsentationsmåde og reklame for sådanne levnedsmidler. Også levnedsmidler, der er bestemt til at leveres til restauranter, hospitaler og lignende storkøkkener, er omfattet af direktivet, jf. artikel 1, stk. 1 og 2.

Mærkningen og dennes nærmere udformning må i medfør af artikel 2 ikke være af en sådan art, at den vildleder køber. Dette gælder især med hensyn til levnedsmidlets beskaffenhed, og især dets art, identitet, sammensætning, mængde, holdbarhed, oprindelsessted m.v.

Der må endvidere heller ikke vildledes ved at tillægge det pågældende levnedsmiddel virkninger eller egenskaber, som det ikke har, eller ved at give indtryk af, at det pågældende levnedsmiddel har særlige egenskaber, når alle lignende levnedsmidler har samme egenskaber.

Med forbehold af de fællesskabsbestemmelser, der gælder for naturligt mineralvand og for levnedsmidler bestemt til særlig ernæring, må der ikke tillægges et levnedsmiddel egenskaber til forebyggelse, behandling og helbredelse af menneskelig sygdom eller give indtryk af sådanne egenskaber, idet der herved ville være en nærliggende fare for vildledning af forbrugerne.

Direktivet er i medfør af artikel 2, stk. 2, udstyret med et bilag indeholdende en ikke-udtømmende liste over de anprisninger, hvis anvendelse under alle forhold bør forbydes eller begrænses.

Forbudene og restriktionerne i henhold til artikel 2 gælder såvel levnedsmidlets mærkning, udformning, præsentationsmåde, levnedsmidlernes eller emballagens form og udseende, det materiale, der anvendes til emballage, den måde, hvorpå levnedsmidlerne er arrangeret, de forhold, hvorunder de udstilles og reklame for levnedsmidlerne. 


\subsection{Anden EU-regulering}

De under punkt 2.2-2.6 nævnte direktiver udgør den for denne rapports område mest relevante EU-regulering af markedsføring med et bredt, generelt sigte. Hertil kommer en række specifikke reguleringer, der indeholder regler om vildledning. Der kan således nævnes:

Forordning om EF-varemcerker, der i artikel 7, litra g, forbyder registrering af varemærker, som vil kunne vildlede offentligheden, f.eks. med hensyn til en vares eller tjenesteydelses art, beskaffenhed eller geografiske oprindelse.

Forordning om genetisk modificerede fødevarer og foderstoffer, der i artikel 4 bl.a. bestemmer, at genetisk modificerede fødevarer ikke må have negative virkninger for menneskers eller dyrs sundhed eller vildlede forbrugerne.

Direktiv 2002/46/EF om kosttilskud indeholder ikke et vildledningsforbud, men artikel 7 bestemmer, at det ikke er tilladt ved markedsføring af kosttilskud at anføre eller antyde, at en afbalanceret og varieret kost generelt ikke kan give tilstrækkelige mængder næringsstoffer. Artikel 6 medfører, at det ikke er tilladt at henvise til, at kosttilskud har egenskaber, der kan forebygge, lindre eller helbrede sygdomme hos mennesker.

Direktiv om fremstilling, presentation og salg af tobaksvarer (EP og R dir 2001/37) forbyder anvendelse af ord som »light«, »lavt tjæreindhold «, »mild« m.v. i tobak, da sådanne udtryk kan være vildledende for forbrugerne. Ligeledes må heller ikke tekst, navne, billeder, figurer eller andet antyde, at en bestemt tobaksvare er mindre skadelig, jf. artikel 7.

EP og R Direktiv 2003/33 om reklame for tobaksvarer m.v. forbyder reklamer for tobaksvarer i pressen og andre trykte publikationer samt i radioen, jf. artikel 3. Tv reklamer for tobaksvarer blev forbudt ved dir. 89/554 EØF. Vildledningsspørgsmålet bliver hermed underordnet, da det som regel vil være reklamens ulovlighed snarere end dens vildledende effekt, der påkalder sig myndighedernes opmærksomhed.

EU-reglerne indeholder endvidere en række direktiver om kontrol af kosmetiske midler og om kemiske produkter af forskellig art, bl.a. forordning om væske og rengøringsmidler (Kom 2003/306).

Disse ovennævnte direktiver og forordninger, der regulerer enkelte områder eller produkter, udgør den retlige minimumsregulering, der skal være til stede i de enkelte medlemsstater.

\subsection{Sammenfatning af EU-reguleringen}

Der gælder dels en generel (kommende) regulering af hele markedsføringsområdet og dels en specialregulering for enkelte varer/områder/salgsformer. Disse to niveauer skal supplere hinanden således, at hvor der gælder en særlig sektorlovgivning på fællesskabsplan, 
finder denne særregulering fortsat anvendelse. Direktivet om urimelig handelspraksis finder således kun anvendelse, hvis der ikke er specifikke fællesskabsbestemmelser om særlige aspekter af urimelig handelspraksis, som f.eks. oplysningskrav og bestemmelser om, hvordan oplysningerne skal præsenteres vedrørende et særligt produkt over for forbrugerne. Dette nye direktiv om urimelig handelspraksis vil på denne måde indføre beskyttelse for forbrugernes økonomiske interesser på områder, hvor der ikke er en særlig sektorlovgivning på fællesskabsplan, og forbyder erhvervsdrivende at bibringe et fejlagtigt/vildledende indtryk af et produkts egenskaber.

Det eneste eksisterende direktiv, der vil blive absorberet af direktiverne om urimelig handelspraksis, er direktivet om vildledende reklame (der dog fortsat gælder vedrørende vildledning af erhvervsdrivende og vedrørende sammenlignende reklame). Den store mængde af andre horisontale og vertikale direktiver vil således fortsat eksistere.

Fødevareområdet er med bl.a. fødevareforordningen og mærkningsdirektivet ganske tæt reguleret, hvilket kun giver plads til få og små nationale forskelle i den retlige regulering. 


\section{Danmark}

\subsection{Generel regulering af vildledning}

\subsubsection{Markedsføringsloven og Forbrugerombudsmanden}

Markedsføringsloven regulerer markedsføring foretaget i privat erhvervsvirksomhed og i offentlig virksomhed, der kan sidestilles hermed. Den danske markedsføringslov er under revision, og en ny markedsføringslov træder i kraft den 1. juli 2006, hvorefter vildledningsforbudet vil være at finde i lovens $\S 3$, men hovedprincipperne om god markedsføringsskik og vildledningsforbudet er stort set uændret i den nye lov.

Forbrugerombudsmanden fører tilsyn med, at loven og de i medfør af loven udstedte bekendtgørelser overholdes navnlig ud fra hensynet til forbrugerne, jf. lovens $\S 15$ (den nye lovs $\S 22$ ). Forbrugerombudsmanden skal ved forhandling søge at påvirke de erhvervsdrivende til at handle i overensstemmelse med principperne for god markedsføringsskik og til at overholde loven i øvrigt. Hvis en erhvervsdrivende ikke kan forhandles til at overholde loven, kan Forbrugerombudsmanden rejse sag om påbud, forbud eller straf, eller Forbrugerombudsmanden kan eventuelt selv nedlægge et midlertidigt forbud. I straffesager møder Forbrugerombudsmanden for anklagemyndigheden, såfremt dette skønnes hensigtsmæssigt.

Sager vedrørende overtrædelse af markedsføringsloven anlægges ved Sø- og Handelsretten med mulighed for anke til Højesteret.

Markedsføringslovens § 1 indeholder markedsføringsrettens hovedbestemmelse og lovens grundlæggende princip formuleret som en generalklausul, hvorefter der i markedsføringsvirksomhed ikke må foretages handlinger, som strider mod god markedsføringsskik. Denne regel gælder overalt for dansk markedsføring, og der findes ikke i særlovgivningen nogen regel, der på samme måde dækker alle former for markedsføring, alle stadier i markedsføringsprocessen og alle medier.

Det anses bl.a. som markedsføring i strid med god markedsføringsskik og markedsføringslovens $\S 1$ at anvende urigtige, vildledende eller urimeligt mangelfulde markedsføringsmetoder. Generalklausulen i § 1 er suppleret af lovens $\S 2$, hvorefter der ikke må anvendes urigtige, vildledende eller urimeligt mangelfulde angivelser eller fremgangsmåde, der er egnet til at påvirke efterspørgsel eller udbud af varer m.v.

Udgangspunktet er, at alle brancher og alle typer erhvervsvirksomhed er omfattet af den generelle regulering i markedsføringsloven, og dermed af Forbrugerombudsmandens tilsyn. Undtaget herfra er kun finansielle virksomheder. Hverken reglen om god markedsføringsskik i markedsfø- 
ringslovens $\S 1$ eller vildledningsforbudet i markedsføringslovens $\S 2$ gælder for sådanne virksomheder i det omfang økonomi- og erhvervsministeren har udstedt regler om de pågældende forhold, jf. markedsføringslovens $\S 1$, stk. 2, og $\S 2$, stk. 5. For de forhold, hvor økonomi- og erhvervsministeren ikke har udstedt regler, gælder markedsføringsloven dog også for finansielle virksomheder under Forbrugerombudsmandens tilsynskompetence.

Markedsføringsloven tilsigter at afveje hensynet til såvel forbrugerne, de erhvervsdrivende og til almene samfundsinteresser. Disse hensyn kan (og skal) indgå i den løbende udformning af normdannelse og videreudvikling af begrebet god markedsføringsskik. Generalklausulen kan benyttes til indgreb mod alle former for uønskede salgs- og reklameforanstaltninger samt mod efterligning, renommésnyltning eller anden udnyttelse af andres indsats, urimelige aftalevilkår, farlige eller underlødige produkter, beskyttelse af den personlige integritet og privatlivets fred m.v.

Anvendelse af brede retsstandarder, som f.eks. begrebet "god markedsføringsskik « medfører en vis retsusikkerhed, og som konsekvens heraf kan den retsstridige adfærd ikke være så veldefineret, at den umiddelbart kan straffes. Markedsføringslovens § 1 er i konsekvens heraf ikke strafsanktioneret. Handlinger i strid med markedsføringslovens $\S 1$ kan i henhold til lovens $\S 13$, stk. 1, forbydes ved dom. Sag om påbud og forbud kan anlægges af Forbrugerombudsmanden samt af enhver anden, der har retlig interesse heri, jf. § 19, stk. 1. En forbudssag følger retsplejelovens regler om civile retssager. Et nedlagt forbud medfører, at det bliver ulovligt at fortsætte med den pågældende handling, således at overtrcedelse af forbudet kan straffes efter markedsføringslovens $\S 22$, stk. 1. Straffen for overtrædelse af vildledningsforbudet er bøde, medmindre højere straf er forskyldt efter anden lovgivning.

Der fastsættes i Danmark ikke i en forbudssag med det samme bod for en eventuel overtrædelse af forbudet, således som det ellers gøres i flere af de andre nordiske lande. Der skal således føres to sager - en forbudssag og en straffesag - for at en overtrædelse af et forbud udløser strafsanktioner.

Overtrædelse af vildledningsforbudet i markedsføringslovens $\S 2$ er dog umiddelbart strafsanktioneret, jf. § 22. Det fremgår af § 22, at straf for overtrædelse af $\S 2$ ikke kræver fortsæt, men alene en realisering af gerningsindholdet, hvilket vil sige en markedsføring, der må bedømmes som vildledende.

Markedsføringslovens $\S 1$ dækker som nævnt lovens specialbestemmelser og dermed også vildledningsforbudet, og $\S 1$ får dermed karakter af at være en opsamlingsbestemmelse og et supplement i forhold til bl.a. vildledningsforbudet i $\S 2$. Dette medfører, at en markedsføringsadfærd, som er vildledende, men som af en eller anden årsag ikke kan straffes, kan forbydes efter $\S 1$. Markedsføringslovens $\S 1$ er herudover også en bestemmelse, der supplerer særlovgivningen, der mange steder indehol- 
der en regel om vildledning, men ikke nogen, der har samme indhold som markedsføringslovens $\S 1$. Selv om den generelle markedsføring således er underlagt Forbrugerombudsmandens tilsyn, er der dog en tilbageholdenhed med at føre dette tilsyn på de områder, hvor der er en myndighed med særlig tilsynskompetence.

I praksis anvendes markedsføringslovens $\S \S 1$ og 2 ofte sammen, og mange domme citerer begge regler.

Vildledningsforbudet i § 2 varetager såvel hensynet til de erhvervsdrivende som til forbrugerne. Bestemmelsen rammer både de direkte fejlagtige oplysninger og de urimeligt mangelfulde angivelser, og den omfatter såvel sproglige som nonverbale former for vildledning. Også oplysning om uvedkommende forhold kan være vildledende.

Konkrete oplysninger er underlagt et sandfærdighedskrav og et dokumentationskrav, jf. § 2, stk. 4, mens rene anprisninger ikke skal dokumenteres, såfremt det klart fremgår, at der alene er tale om anprisninger. Der kan dog være tale om vildledning, selvom en oplysning eller et udsagn objektivt set er korrekt. Det afgørende er, om det pågældende udsagn er egnet til at efterlade et ukorrekt indtryk hos kunderne og dermed kan virke vildledende.

Såvel fysiske som juridiske personer kan straffes efter markedsføringsloven, jf. dennes $\S 22$, stk. 6 og enhver, der har medvirket til overtrædelsen kan straffes for medvirken.

\subsubsection{Praksis vedrørende overtrcedelse af markedsføringslovens vildledningsregler}

Markedsføringsloven finder anvendelse på alle former for markedsføring og vedrørende alle typer af produkter Der føres ikke mange sager til dom i Danmark, idet langt de fleste afsluttes på et tidligere stadium ved forhandlinger mellem den erhvervsdrivende og Forbrugerombudsmanden. Da særlovgivningens regler om vildledning er lex specialis, finder markedsføringslovens vildledningsregler kun sjældent anvendelse på markedsføring af produkter, der er reguleret af en af særlovene. Således findes der kun et par sager fra 1990 og 1991 om markedsføring af levnedsmidler. I den første sag drejede det sig om vildledning af, hvorvidt man fik en »MiniMuh« med ved køb af en lille plade chokolade, og i den anden drejede sagen sig om vildledende angivelse af fedtprocent i svinekød. Begge sager endte med at de erhvervsdrivende lovede at ophøre med den vildledende markedsføring.

Niveauet for bødestraffen ved markedsføringsforseelser er steget markant gennem de seneste år efter i en årrække at have været af en størrelsesorden, der næppe kan have haft nogen nævneværdig præventiv effekt. Højesteret har dog i flere sager nedsat de meget store bøder, som Sø- og Handelsretten havde pålagt for overtrædelse af markedsføringsloven. 
Forbrugerombudsmanden havde foreslået et princip, hvorefter bøder i medfør af markedsføringsloven skulle opgøres i forhold til de anvendte markedsføringsudgifter ekskl. moms, og dette princip er nu lagt til grund i lovbemærkningerne til markedsføringslovens § 22, hvoraf fremgår, at det er hensigten at søge strafniveauet skærpet, »navnlig hvor overtrædelsen, bedømt efter markedsføringsindsatsens økonomiske størrelse, er af betydeligt omfang. En sådan skærpelse bør dels være, at der også ved omfattende overtrædelser anvendes samme forhold mellem markedsføringens økonomiske omfang og bødens størrelse, som ved mindre overtrædelser, dels at strafudmålingen generelt skærpes, således at der ved førstegangsovertrædelser af markedsføringslovens $§ 2$ gives bøder på det dobbelte af markedsføringsudgiften, og at der ved specialforbudene sker en tilsvarende skærpelse. Såfremt det kan sandsynliggøres, at en større fortjeneste har været tilstræbt, bør der tages hensyn hertil. Der er dog rejst betænkelighed ved, at et sådant princip kan medføre betydelig større strenghed i sanktioneringen af markedsføringsovertrædelser end i øvrigt i dansk ret.

Der er også forsøgt fastlagt niveau for anden overtrædelse af markedsføringsloven end $\S 2$. Således vedrørende forbudet mod uanmodet elektronisk henvendelse (spam), hvor man forsøgte at anlægge en "grundbøde« på 10.000 DKK for op til 100 overtrædelser og 100 DKK for hver overtrædelse over 100. Domstolene har tiltrådt et sådant princip, men har foretaget en nedrunding ved et stort antal spam-mails - telefax eller sms'er. Således senest, hvor Højesteret nedsatte Landsrettens bøder fra 2 mill. DKK til 400.000 DKK

Straf for overtrædelse af markedsføringslovens $\S 2$ er ofte kombineret med straf for overtrædelse af et eller flere af lovens specialforbud, hvorfor det kan være vanskeligt at bedømme et bødeniveau for overtrædelse af $\S 2$ isoleret set.

I en ikke offentliggjort sag fra 1997 vedtog lavprisvarehuset Bilka en bøde på 400.000 DKK for overtrædelse af markedsføringslovens dokumentationskrav ved prisangivelser.

I U $1998.950 \mathrm{H}$ blev to personer, der stod bag et postordrefirma, idømt hver en bøde på 250.000 DKK for krænkelse af markedsføringslovens $\S \S 2$ og 6 (tilgiftsreglen). De havde udsendt et "vindercertifikat", som intet reelt indhold havde, men som lokkede forbrugerne til at indsende 100 DKK mod modtagelse af varer af en meget ringe værdi. Der blev ved udmålingen af bødens størrelse lagt vægt på de foreliggende oplysninger om den opnåede eller tilsigtede fortjeneste, jf. straffelovens $\S 51$, stk. 7.

I U 1999.1594 H blev straffen for flere tilfælde af vildledende markedsføring samt ydelse af og reklamering med tilgift fastsat til 250.000 DKK Der var tale om grove overtrædelser og gentagelse af forholdet efter, at man havde lovet Forbrugerombudsmanden at ophøre med den ulovlige markedsføring. 
I U 2000.2064 S fik en erhvervsdrivende en bøde på 125.000 DKK for vildledende tv-annoncering. Et tilbud på dyner til 50 DKK måtte forstås som omfattende alle dyner i butikken og ikke kun dem, som før havde kostet 150 DKK Bøden blev nedsat med den begrundelse, at den erhvervsdrivende havde forsøgt at standse reklamen, da han erfarede kundernes reaktioner på reklamerne.

I Juridisk Årbog 2000 nævnes en sag, hvor en virksomhed vedtog en bøde på 400.000 DKK for overtrædelse af markedsføringslovens $\S 2$, stk. 1 og stk. 3, og $\S 6$. Dette firma lovede store præmier ved bestilling af varer for mindst $150 \mathrm{DKK}$, men de rosende omtalte præmier var uanvendelige og unyttige genstande til en værdi af 15-17 DKK

Ved utrykte domme af henholdsvis 20.4.2001 og 19.6.2002 har Sø- og Handelsretten idømt et postordrefirma samt dets direktør og eneanpartshaver hver en bøde på 1 mill. DKK for overtrædelse af markedsføringslovens $\S \S 2,6$ og 9 for i forbindelse med udsendelse af i hvert fald ca. 320.000 personligt stilede breve at have vildledt forbrugerne og tilbudt tilgift og præmiekonkurrencer i strid med markedsføringsloven. Bøden fastsattes efter et samlet skøn over den opnåede eller tilsigtede fortjeneste, herunder størrelsen af markedsføringsomkostningerne.

I U 2003.827 H blev et selskab ved Højesteret idømt en bøde på 2 mill. DKK (Ved Sø- og Handelsretten var bøden sat til 3 mill. DKK). Selskabet havde ved salg af præmieobligationer ydet ulovlig tilgift i form af ure, kameraer m.v. samt anvendt urigtige, vildledende eller urimeligt mangelfulde oplysninger. Under hensyn til størrelsen af selskabets markedsføringsomkostninger (godt 3 mill. DKK) samt overtrædelsens omfang og grovhed, fastsatte Højesteret straffen til en bøde på 2 mill. DKK

\subsubsection{Konklusion vedrørende bødeniveauet i henhold til markedsføringsloven}

Der er relativt få straffesager i dansk retspraksis og bøderne fastsættes individuelt. Konklusionen på straffeniveauet vedrørende overtrædelse af markedsføringslovens forbud mod vildledning er, at størrelsen af de idømte bøder udregnes i forhold til markedsføringsomkostningernes størrelse, den tilsigtede fortjeneste, forholdets grovhed, om der er sket gentagelser af overtrædelserne, eller om der er tale om et enkeltstående tilfælde, og antallet af forbrugere, som denne markedsføringsadfærd retter sig imod.

Bødernes størrelse er i de seneste år steget således, at større, alvorligere overtrædelser takseres med bøder fra 100.000 DKK og opefter, og der er senest idømt bøder på 125.000 DKK, 250.000 DKK, 400.000 DKK, 1 mill. DKK og 2 mill. DKK 


\subsection{Fødevarer}

\subsubsection{Fødevareloven og Fødevarestyrelsen}

Hele fødevareområdet er i stort omfang underlagt fælles EU-regler. Dette gælder blandt andet mærkning af fødevarer. Det enkelte land kan derfor kun i meget begrænset omfang selv fastsætte regler på fødevareområdet. De love, der gælder på området, er rammelove, hvilket også gælder fødevareloven, hvilket betyder, at lovens bestemmelser er konkretiseret i en række bekendtgørelser, jf. nedenfor. Der er dog i EU-reglerne ikke noget fastlagt om, hvilket strafniveau, der skal lægges for overtrædelse af reglerne og ej heller for arten og intensiteten af offentlig kontrol med området.

Lov om fødevarer (lov nr. 526 af 24. juni 2005) regulerer fødevareområdet på det overordnede plan. Loven er netop blevet ændret med henblik på at tilpasse loven til EU-retsakter på fødevareområdet (bl.a. fødevare forordningen). Lovens formål er bl.a. at sikre forbrugerne mod sundhedsrisiko i forbindelse med fødevarer, at sikre forbrugerne fødevarer af høj kvalitet, at beskytte forbrugerne mod vildledning - herunder gennem anprisninger - i forbindelse med markedsføring af fødevarer m.v.

Dette skal ifølge forarbejderne til loven understøttes gennem en effektiv og behovsorienteret offentlig kontrol i alle led af produktion og omsætning af fødevarer

Tendensen i EU er, at retsgrundlaget på fællesskabsplan ændres fra direktivbaseret til regulering ved hjælp af forordninger. I konsekvens heraf bliver en række bestemmelser erstattet af bemyndigelser til ministeren (rammelovgivning). I forbindelse hermed er det hensigten at implementere direktiver i bekendtgørelser og ikke som hidtil på lovniveau.

Den nye fødevarelov indeholder ikke væsentlige ændringer af den tidligere fødevarelovs formål eller anvendelsesområde og indeholder - som den tidligere lov - et forbud mod vildledning. Praksis efter den tidligere fødevarelovs $\S 19$ kan derfor fortsat anvendes ved beskrivelse af reglernes indhold og funktion.

Vildledningsforbudet i § 14 er udformet som en bred generalklausul: Reklamer for fødevarer, mcerkning og prcesentation af fødevarer, herunder deres form, fremtræden eller indpakning, de anvendte indpakningsmaterialer, den måde hvorpå varerne er arrangeret, og de omgivelser, hvori de udstilles, samt de informationer, der uanset medium, gives om varerne, må ikke vildlede eller vœre egnet til at vildlede. Fødevarelovens $\S 14$ finder kun anvendelse i tilfælde, som ikke er omfattet af fødevareforordningens artikel 16, jf. § 14, stk. 2.

Også anprisninger kan være en fordrejning af de reelle forhold omkring en fødevare, som kan være lige så vildledende som urigtige og vildledende udsagn i øvrigt. Fødevarelovens § 15 regulerer rammerne for regler om fødevareanprisninger, bl.a. sådanne som angår fødevarers 
særligt helbredende eller forebyggende effekt, eller om at en fødevare ikke er i besiddelse af visse egenskaber, eller af at en fødevare er særligt egnet for mennesker med særlige behov. Sådanne anprisninger er kun i begrænset omfang tilladt i Danmark. Almindelige ernæringsmæssige anprisninger er tilladt, forudsat at de kan dokumenteres som rigtige.

Ministeren for familie- og forbrugeranliggender kan fastsætte regler om mærkning, markedsføring eller reklamer for fødevarer, herunder om 1) angivelse af, at fødevarer har en særlig helbredende eller forebyggende effekt, 2) anvendelse af anprisninger om, at en fødevare ikke er i besiddelse af visse egenskaber og 3) anvendelse af anprisninger, der angiver, at en fødevare er særligt egnet for mennesker med behov for særlig kost på grund af sygdom, alder eller andre forhold, eller som angiver at virke forebyggende over for sygdom, jf. § 15. Sådanne vejledninger foreligger bl.a. vedrørende markedsføring af fødevarer, kosttilskud, slankekosttilskud m.m. Tilsynet med overholdelse af lovgivningen varetages af Fødevarestyrelsen.

Der er i medfør af fødevareloven udstedt bekendtgørelser og vejledninger vedrørende markedsføring af fødevarer, bl.a. bekendtgørelse nr. 1308 af 14. december 2005 om mærkning af fødevarer og bekendtgørelse om kosttilskud nr. 683 af 21. juli 2003.

Bekendtgørelse om mærkning m.v. af fødevarer indeholder i §§ 75 og 76 regler om vildledning og anprisninger. Det er forbudt i forbindelse med markedsføring af fødevarer at give indtryk af, at en fødevare har særlige egenskaber, når alle lignende fødevarer har eller efter lovgivningen skal have tilsvarende egenskaber. Det er endvidere forbudt at angive, at fødevarer er anbefalet af læger, eller at indtagelse af den pågældende fødevare kan lindre, forebygge eller have gavnlig virkning på sygdomme eller sygdomssymptomer eller angivelser, der er egnet til at vække eller udnytte angstfølelser hos forbrugerne.

Denne bekendtgørelse er suppleret af Vejledning om forbudet mod vildledende mærkning og markedsføring af fødevarer, som opstiller retningslinjer for en lang række produktområder og anprisende ord og begreber.

Kosttilskud er omfattet af fødevareloven og dertil hørende bekendtgørelser og dermed af dennes regler om vildledning, jf. ovenfor. Tilsynet med kosttilskud er underlagt Fødevarestyrelsen, der kan nedlægge forbud, udstede påbud og pålægge administrative bøder.

Grænsen mellem kosttilskud og naturlægemidler er uskarp, og der er forskel på, hvad der må anføres om produktet, og hvorledes disse produkter behandles administrativt, idet naturlægemidler skal godkendes af Sundhedsstyrelsen, medens kosttilskud alene skal anmeldes til Fødevarestyrelsen Der findes omkring 2000 forskellige produkter, som må anses for at være kosttilskud. Kun ca. 200 af disse var i oktober 2004 anmeldt til myndighederne. Pr. 1. august 2005 skulle alle kosttilskud være anmeldt. 
Kosttilskudsbekendtgørelsen omfatter kosttilskud, der i § 2 defineres som fødevarer, der har til formål at supplere den normale kost, og som er koncentrerede kilder til næringsstof eller andre stoffer med en ernæringsmæssig eller fysiologisk virkning, alene eller kombinerede, og som markedsføres i dosisform (f.eks. vitamintabletter, fiskeoliekapsler m.v.). Der er i september 2005 udfærdiget en ny vejledning om kosttilskud, hvoraf bl.a. fremgår, at anprisninger vedrørende kosttilskud ikke må være egnet til at skabe en forventning hos en almindelig oplyst, rimelig opmærksom og velunderrettet gennemsnitsforbruger om, at vedkommende får noget andet, end det, han/hun faktisk får. Markedsføring må således ikke være vildledende.

Produkter, der ønskes markedsført som kosttilskud, skal anmeldes til den lokale fødevareregion, jf. $\S 5$, og skal være forsynet med varebetegnelsen kosttilskud. Lægemidler må ikke sælges som kosttilskud.

Der er nu oprettet en særlig kosttilskudsenhed under Fødevarestyrelsen, der udelukkende arbejder med kontrol af markedsføringen af kosttilskud. Der slås derfor nu langt oftere ned på vildledningsforsøg (som f.eks. når et produkt indeholdende selen forsøges markedsført mod fugleinfluenza!)

Da overvægt ikke anses for at være en sygdom, er anvendelsen af kosttilskud til slankeformål (slankekosttilskud) ikke midler til bekæmpelse af sygdomstilstande og anses derfor ikke som lægemidler, jf. dommen U $1980.901 \mathrm{H}$, der statuerer, at »overvægt « og »vægtproblemer« ikke er sygdomme. Slankekosttilskud er derfor også reguleret efter reglerne om kosttilskud, hvilket vil sige efter fødevarelovgivningen, eller efter de almindelige markedsføringsregler afhængig af, hvilket middel det drejer sig om. Andre slankemidler som f.eks. magnetarmbånd, slanketøfler, slankekorsetter m.v. er ikke kosttilskud og ikke medicin, hvorfor de reguleres af de almindelige markedsføringsregler i markedsføringsloven.

Sundhedsanprisninger vedrørende fødevarer omfatter alle anprisninger, der omhandler den effekt, som en fødevare eller dens bestanddele udøver på den menneskelige organisme. Fødevarelovens § 20 og mærkningsbekendtgørelsens $\S 76$ regulerer brugen af sundhedsanprisninger i Danmark. Det er herefter ikke tilladt at anvende angivelse af, at en fødevare kan forebygge, lindre eller have gavnlig virkning på sygdomme, mens det som noget nyt er tilladt at anføre såkaldte »ernæringsmæssigt funktionelle sundhedsanprisninger « (functional food). Sådanne funktionelle sundhedsanprisninger (kalk er godt for knoglerne, fiskeolie er godt mod for højt kolesterol) kan indtil videre kun anvendes, hvis de kan dokumenteres eller er baseret på almindeligt anerkendte videnskabelige data.

Uspecifikke anprisninger (bedre velbefindende, godt for maven m.v.) skal kunne dokumenteres og må ikke være egnede til at vildlede forbrugerne. 
Den producent eller forhandler, der er ansvarlig for mærkning eller markedsføring af en fødevare, skal kunne dokumentere, at de fremsatte oplysninger eller påstande er korrekte. Det er således ikke tilsynsmyndigheden, der skal bevise, at oplysningerne er urigtige. Korrekte oplysninger kan dog også her være vildledende. Dette har for nylig været tilfældet i en sag vedrørende vingummislik, der blev solgt under henvisning til, at der var et lavt fedtindhold, at vingummierne var »fedtfattige« og indeholdt "max 0,3 gram fedt«. Nu er det jo ikke fedtindholdet, der er det eneste problem ved indtagelse af slik, og der er ikke mindre fedt i andre tilsvarende produkter. Fødevarestyrelsen har derfor påbudt slikfabrikanten at standse denne reklamekampagne med henvisning til, at den er vildledende.

Fødevarestyrelsen er den overordnede specialmyndighed på området med det faglige, administrative ansvar og hertil kommer de statslige fødevareregioner, der varetager alle de af loven omfattede kontrol- og tilsynsopgaver. Der er således et enstrenget statsligt fødevarekontrolsystem.

I praksis er kontrollen med markedsføringen på fødevareområdet dog begrænset, idet de ressourcer, der er afsat til kontrol, er begrænsede, og hygiejne og sundhedskontrol prioriteres frem for kontrol med vildledende markedsføring. Mulighederne for overtrædelse er talrige, og særligt efter at det er blevet muligt og almindeligt at reklamere for produkter på Internettet, er det blevet næsten umuligt at overvåge markedsføringen i bare nogenlunde omfang. Kontrol og sanktioner er dermed blevet afhængig af forbrugernes eller mediernes reaktioner. De generelt ringe ressourcer til kontrol forsøges dog afbødet med kontrolkampagner. Der er således i 1997-98, 2001 og 2004 ført kontrolkampagner mod vildledende markedsføring. Der kom mange overtrædelser for dagen i 1997-98, og der blev udstedt ca. 200 forbud og påbud, men kun 8 bøder. Ved de senere kontrolkampagner er antallet af påbud og forbud faldet, ligesom bødesagernes antal er blevet reduceret. Dette kan være resultat af det øgede fokus på markedsføringen, men bødernes ringe størrelse, jf. nedenfor, er dog et håndhævelsesproblem. De erhvervsdrivendes modvilje mod dårlig presseomtale og forbrugernes reaktion må nok anses for at være mere motiverende for overholdelsen af love og regler.

Al markedsføring - også af fødevarer - er underlagt markedsføringsloven og dermed Forbrugerombudsmandens tilsyn, men speciallovgivningens regler om vildledning vil være lex specialis, hvorfor der primært skal føres sag om vildledning efter speciallovgivningen og kun efter markedsføringslovens $\S 2$, hvor speciallovgivningen ikke regulerer forholdet eller har et »hul«. Forbrugerombudsmanden er derfor tilbageholdende med kontrol og tilsynsaktiviteter på fødevareområdet.

\subsubsection{Praksis vedrørende fødevarelovgivningen}

Udmålingskriterierne for fastsættelse af sanktioner for overtrædelse af speciallovgivningen - herunder fødevarelovgivningen - følger normalt af 
straffelovens kapitel 10, hvorefter det fremgår, at der ved straffens udmåling skal tages hensyn til lovovertrædelsens grovhed, og til oplysninger om gerningsmandens person og hans forhold før og efter gerningen samt hans bevæggrunde til denne. Det skal endvidere ved strafudmålingen altid tillægges vægt, om overtrædelsen er sket med økonomisk vinding eller besparelse for øje, uanset om den økonomiske fordel faktisk er opnået eller ej, jf. straffelovens § 51, stk. 3, og § 80 .

Fødevarelovens $\S 60$ bestemmer, at overtrædelse af lovens $\S \S 19$ og 20, samt undladelse af at efterkomme de til vedkommende meddelte afgørelser, herunder meddelelsen af påbud og forbud, der er truffet af fødevareregionerne for at sikre overholdelse af de krav, der er fastsat i fødevarelovgivningen eller i EU-forordninger og direktiver, straffes med bøde. Straffen kan stige til fængsel i medfør af § 60, stk. 2, hvis overtrædelsen er begået med fortsæt eller grov uagtsomhed, og der enten er forvoldt skade på sundheden eller fremkaldt fare herfor, eller der er opnået/tilsigtet økonomisk fordel for den pågældende selv eller andre. Skønnes en overtrædelse ikke at ville medføre en højere straf end bøde, kan sagen afgøres ved en administrativ bøde.

Det udtales i forarbejderne til den nye fødevarelovs $\S 60$, at det hidtidige basis-bødeniveau for overtrædelse vurderes på nogle områder at være for lavt. Der har siden ikrafttrædelsen af fødevareloven af 1998 været afsagt en række domme, der på visse områder har dannet fast retspraksis for fastsættelse af bøder. På de områder, hvor der er dannet en praksis, ligger normalbødestørrelserne mellem 1.000 DKK og 20.000 $D K K$ »Standardbøden« er omkring 10.000 DKK, hvilket for en stor virksomhed næppe kan have den ønskede præventive effekt, ligesom anvendelse af faste bødestørrelser bevirker, at den store virksomhed slipper forholdsvist lettere end den lille. Der har ikke på fødevareområdet været praksis for at forsøge at fastsætte bøden til det beløb, der er anvendt på markedsføringen (hvilket ved store kampagner ofte andrager meget store beløb) som er eller tjent/forsøgt tjent ved overtrædelsen. De højeste bøder på fødevareområdet er på 50.000 DKK

Der lægges i forarbejderne til den nye fødevarelov til grund, at straffeniveauet bør hæves, således at den præventive effekt forholdsmæssigt bliver bedre for virksomhederne uanset disses omsætning. Princippet for forhøjelsen skal svare til det, som gælder for beregningen af bøder efter konkurrenceloven, men det tilsigtes ikke, at det bødeniveau, der kendes fra konkurrencelovgivningen, skal overføres til fødevarelovgivningen. Formålet er alene, jf. bemærkningerne, at de hensyn, der ligger bag udmålingen af bødestraf skal være ens i de situationer, hvor en af konsekvenserne ved overtrædelse af en regel i fødevarelovgivningen er, at fødevarevirksomheden stilles i en mere fordelagtig konkurrencesituation. Hermed skulle det ifølge bemærkningerne til lovforslaget kunne undgås, at store virksomheder med de nugældende bødestørrelser betragter bødesanktioner som almindelige driftsomkostninger. 
Der er ikke offentliggjort mange domme vedrørende bøder pålagt i medfør af fødevarelovgivningens vildledningsforbud. De seneste to domme vedrører frifindelser for overtrædelse af vildledningsforbudet, hvor anvendelse af betegnelsen »hjemmelavet chokolade« ikke kunne anses for at være vildledende markedsføring efter fødevarelovens $\S 19$ (nu § 14), jf. U 2002.908 Ø, og anvendelsen af betegnelsen »Rigtig Juice« ikke fandtes vildledende efter den dagældende levnedsmiddellovs $\S 23$, jf. U 2001.2161 Ø. I begge sager blev derfor de af Fødevaredirektoratet nedlagte forbud og påbud ophævet.

\subsubsection{Konklusion vedrørende bødeniveauet for vildledning på fødevareområdet}

De bøder, der hidtil er blevet givet for overtrædelse af vildledningsforbudet på fødevareområdet har været meget små, set i forhold til de bøder, der nu gives for overtrædelser på markedsføringslovens område. Bødeniveauet ligger for en »normalbøde« mellem 5.000 og 20.000 DKK med en "standardbøde“ på 10.000 DKK og højeste bøde på 50.000 DKK I forarbejderne til den nye fødevarelov er det imidlertid lagt til grund, at dette niveau bør hæves.

Såfremt man for alvor skal opnå en egentlig præventiv virkning, bør bødeniveauet hæves til det niveau, der nu lægges til grund ved overtrædelse af markedsføringsloven, hvor der gives individuelt udmålte bøder på senest op til 2 mill. DKK ved alvorlige overtrædelser. Dette må dog suppleres med en mere effektiv kontrol, således at overtrædelser reelt risikerer opdagelse og strafforfølgning.

\subsection{Sundhed: Alternative behandlinger, naturmedicin, slankemidler, alkohol og tobak.}

\subsubsection{Regler og tilsynsmyndigheder}

Det sundhedsmæssige område spænder meget bredt, men denne rapport afgrænser sig til alene at se på retstilstanden vedrørende markedsføring til forbrugere af alternative behandlinger, naturmedicin, slankemidler samt alkohol og tobak.

Lægemiddelloven regulerer alle produkter, der er »bestemt til at tilføres mennesker eller dyr for at forebygge, erkende, lindre, behandle eller helbrede sygdom, sygdomssymptomer og smerter eller for at påvirke legemsfunktioner (lægemidler), jf. lægemiddellovens § 1. Lovens definition er indholdsmæssigt i overensstemmelse med definitionen i EUdirektiv om lægemidler (R dir 65/65). Naturlegemidler er undtaget fra lægemiddellovens dokumentationskrav i medfør af dennes § 3, stk. 2, § 15, stk. 2, og $\S 44$, stk. 2, hvorefter sundhedsministeren kan undtage 
bestemte varer eller varegrupper, der er omfattet af $\S 1$ helt eller delvist fra loven, som fastsætter regler om udstedelse af markedsføringstilladelse til naturlægemidler, homøopatiske lægemidler og vitamin- og mineralpræparater. Ved naturlægemidler forstås lægemidler, der udelukkende indeholder naturligt forekommende stoffer i koncentrationer, der ikke er væsentligt større end dem, hvori de forekommer i naturen. Naturlægemidler hører under Lægemiddelstyrelsens tilsynsområde, og skal igennem en godkendelsesprocedure, før de må markedsføres. De skal således leve op til en række af de samme krav, som almindelige lægemidler vedrørende renhed, kontrol doseringsanvisninger m.v.

Slankekosttilskud behandles som andre kosttilskud og er beskrevet under fødevareafsnittet ovenfor. Reklamering med »alternative behandlingsformer« så som plastre, gin seng cigaretter, magnetiske armbånd, slanketøfler, lykkeamuletter og lignende udgør en gråzone, idet mange af midlerne hverken er fødevarer eller lægemidler, men ligger lidt midt imellem det hele. En del af disse produkter må høre under Forbrugerombudsmandens tilsyn og reguleres efter markedsføringslovens regler om vildledning og kravet om dokumenterbarhed for konkrete oplysninger.

Egentlige alternative behandlingsformer som akupunktur, zoneterapi m.v. hører under Sundhedsstyrelsens tilsyn.

Tobak er underlagt lov om tobak, hvorefter det i medfør af $\S 3$, stk. 1 jf. $\S 1$ er forbudt at reklamere for tobaksvarer. Dette gør at problemstillingen, om en markedsføring er vildledende, i høj grad ændres til spørgsmålet, om en vare er en tobaksvare og reklamen derfor er forbudt. En sådan markedsføring ville være omfattet af markedsføringslovens $\S 1$ om handlinger i strid med god markedsføring samt af tobakslovens forbud mod reklame. Tilsynet med overholdelse af tobaksloven en underlagt Forbrugerombudsmanden. Sager om overtrædelse af tobaksloven straffes med bøder, senest således i begyndelsen af 2006 med en bøde på 50.000 DKK

Alkohol er ikke i dansk ret undergivet lovmæssige restriktioner for markedsføringen, men der er fra Forbrugerombudsmandens side i samarbejde med brancherepræsentanter udfærdiget retningslinjer om alkoholreklamer. Tilsynet med overholdelse af reglerne om alkoholreklamer er underlagt Forbrugerombudsmanden, og der føres jævnligt sager om overtrædelse heraf, men det har ikke været vildledningsproblemerne, der har været genstand for Forbrugerombudsmandens opmærksomhed, men snarere etiske og samfundsmæssige forhold. Dette har været tilfældet ved en sag vedrørende salg af stærke drikke »forklædt« som sodavand og målrettet unge forbrugere.

\subsubsection{Praksis vedrørende overtrcedelse vildledningsforbudene}

Der er kun få sager offentliggjort vedrørende vildledende markedsføring af de slankeprodukter, alkohol og tobak, der henhører under Forbrugerombudsmandens tilsyn. Bødeniveauet må derfor forventes at ligge på linje 
med overtrædelse af markedsføringslovens almindelige bestemmelser om vildledning. Der er således givet bøder på det dobbelte af annonceprisen ekskl. Moms i afgørelser vedrørende overtrædelse af tobaksloven.

Lægemidler hører under Sundhedsstyrelsen men der føres meget lidt tilsyn hermed. Der findes således også i annonceblade, kuponhæfter m.v. talrige eksempler på overtrædelser. Overtrædelse af reglerne om anprisninger og vildledning medfører som oftest i første omgang en forhandling om ændring af markedsføringen og et salgsforbud, og ved grove overtrædelser vil myndighederne udstede en administrativ bøde, som typisk er på $10.000 \mathrm{DKK}$

\subsubsection{Konklusion vedrørende bødeniveauet for sundhedsområdet}

Den del af sundhedsområdet, der henhører under Forbrugerombudsmandens tilsyn må forventes at ville følge praksis for bødeniveauet efter markedsføringsloven. For alternativ medicin gælder, at mange overtrædelser ikke påtales, og overtrædelse af reglerne om anprisninger og vildledning i langt de fleste tilfælde afsluttes med et salgsforbud, og ved grove overtrædelser vil myndighederne udstede en administrativ bøde, som typisk er på 10.000 DKK Denne praksis giver i realiteten ret fri adgang for de erhvervsdrivende til at udforme deres markedsføring stort set risikofrit. Hertil kommer, at en stor del af den retsstridige markedsføring foregår på Internettet og på tværs af landegrænserne, hvilket yderligere vanskeliggør kontrol og tilsyn.

\subsection{Miljø: Miljøargumenter, kemiske produkter, kosmetik}

\subsubsection{Regler og tilsynsmyndigheder}

De nordiske forbrugerombudsmænd har i februar 2005 udgivet en fælles vejledning om brug af etiske og miljømæssige påstande og udsagn i markedsføringen, som er en fornyelse og udvidelse af den tidligere vejledning fra 1994. Udgangspunktet i vejledningen er, at såfremt der er speciallovgivning, hvori der er særlige krav til markedsføringen, skal speciallovgivningen overholdes.

Forbrugerombudsmanden fører i Danmark tilsyn brugen af miljøargumenter i markedsføringen og følger i sin praksis denne fælles nordiske vejledning om miljøargumenter i markedsføringen. Dette gælder f.eks. argumenter som "grøn«, »uskadeligt for miljøet « m.v.

Brugen af etiske og miljømæssige påstande såsom udsagn / oplysninger, symboler og/eller mærkeordninger i markedsføringen, som giver indtryk af, at virksomheden tager særlige etiske, sociale, miljømæssige eller samfundsmæssige hensyn, eller at produktet eller tjenesteydelsen har sådanne særlige egenskaber, skal ligge inden for rammerne af reglerne i 
markedsføringsloven.. Vejledningen indeholder regler om, at budskaberne må fremføres tydeligt og afbalanceret, bedømt efter helhedsindtrykket, og at påstande skal kunne dokumenteres.

Markedsføringsmæssige handlinger i strid med en sådan vejledning er ikke umiddelbart strafsanktionerede, men sådan overtrædelse kan forbydes, hvorefter en overtrædelse af et sådant forbud kan straffes, jf. markedsføringslovens $\S 22$.

Produkters indhold, sammensætning og andre mere tekniske forhold er reguleret ved bl.a. lov om kemiske stoffer og produkter (lov nr. 21 af 16. januar 1996 med senere ændringer), der har til formål at forebygge sundhedsfare og miljøskader i forbindelse med fremstilling, opbevaring, anvendelse og bortskaffelse af kemiske stoffer og produkter. Lovens $\S$ 10, stk. 3, bestemmer, at et kemisk stof eller produkt ikke må sælges under omstændigheder, der er egnet til at vildlede brugerne med hensyn til stoffets eller produktets anvendelse eller med hensyn til den risiko, der kan være forbundet med stoffet eller produktet.

Miljø- og energiministeren kan fastsætte nærmere regler om forbudet mod vildledning, herunder om at bestemte udsagn eller angivelser anses for vildledende, jf. § 10, stk. 4. Dette er sket med Miljø- og Energiministeriets bekendtgørelse om klassificering, emballering, mærkning, salg og opbevaring af kemiske stoffer og produkter. Denne bekendtgørelse forbyder bl.a. vildledning, som skal beskytte forbrugerne mod vildledning, der skal få forbrugerne til at tro, at et stof var uskadeligt, selv om det eventuelt udgør en risiko for sundhed eller miljø. Dette vedrører f.eks. ord som »økologisk«, »grøn«, »ufarlig «, »allergitestet « m.m. Overtrædelse af vildledningsforbudet i § 10, stk. 3, straffes i medfør af $\S 59$ med bøde, hæfte eller fængsel i indtil 2 år.

Da kemikalielovgivningens bestemmelser om vildledende markedsføring alene retter sig mod kemiske produkter, kan der forekomme tilfælde, hvor der anvendes vildledende angivelser om andre varers kemiske egenskaber, f. eks. reklamering med, at et køleskab er freonfrit. Disse sager kan alene behandles efter markedsføringsloven, men Forbrugerombudsmanden rejser næsten aldrig sager på disse områder, da Forbrugerombudsmanden ikke besidder den faglige indsigt og ekspertise på området.

Markedsføring af kosmetik er reguleret i bekendtgørelsen om kosmetiske produkter nr. 74 af 14 . januar 2005, som regulerer mærkning af kosmetik, bl.a. hudcreme, deodoranter, sæbe, shampoo, hårfjerningsmidler, tandpasta m.v. Denne bekendtgørelses $\S 11$ indeholder ligeledes et forbud mod vildledende markedsføring, og bestemmelsen er sanktioneret med straf, jr. § 35 .

Kosmetiske midler må ikke kunne være til skade for menneskets sundhed, når de anvendes under normale betingelser eller under betingelser, der med rimelighed kunne forudses, jf. § 9. Kosmetiske produkter må ikke markedsføres under omstændigheder, der er egnet til at vildlede forbrugerne med hensyn til produktets anvendelse eller med hensyn til 
den risiko, der er forbundet med produktet. Udsagn som »allergitestet«, »klinisk testet«, »dermatologisk testet « o. lign. anses som værende vildledende for brugeren, jf. § 9, stk. 2. Ligeledes kan oplysninger om indholdets vægt eller volumen være vildledende.

Tilsyn og kontrol med overholdelse af reglerne i kosmetikbekendtgørelsen udøves af Miljøstyrelsen, jf. § 32.

Overtrædelse af en række af bekendtgørelsens regler - herunder bl.a. § 9 - straffes med bøde, medmindre højere straf er forskyldt efter den øvrige lovgivning, jf. § 33. Straffen kan stige til fængsel i indtil 2 år, hvis overtrædelsen er begået forsætligt eller ved grov uagtsomhed, og hvis der ved overtrædelsen er voldt skade på menneskers liv eller sundhed eller fremkaldt fare herfor eller opnået eller tilsigtet en økonomisk fordel, herunder besparelser for den pågældende selv eller andre.

\subsubsection{Praksis vedrørende miljøargumenter m.v.}

Der er offentliggjort meget få sager vedrørende overtrædelse af reglerne om forbud mod vildledning vedrørende kemiske stoffer, kosmetik m.v. De sager, der føres af Forbrugerombudsmanden ender stort set med, at den erhvervsdrivende frivilligt ændrer sin markedsføring.

I de sager, der føres af miljømyndighederne, og som ender med bøde er bødeniveauet lavt. Der er således i marts 2006 offentliggjort en af de sjældne sager, hvor der er rejst tiltale for domstolene. Denne sag, der omhandlede salg af badevinger med for højt indhold af ptalat, og således ikke en sag om vildledning endte i Landsretten med en bøde på 5.000 DKK Praksis vedrørende kosmetikbekendtgørelsen viser, at bøder typisk ligger på 10-15.000 DKK også i tilfælde, hvor overtrædelsen er sket forsætligt og i modstrid med påbud.

3.4.3 Konklusion vedrørende bødeniveauet for miljøargumenter, kemiske produkter, kosmetik m.v.

Disse produkter overvåges af forbrugerombudsmanden for så vidt angår vildledende anvendelse af miljøargumenter, hvor der dog ikke ses offentliggjort sager, der er endt med bødestraf.

Hvor særlovgivningen er overtrådt, er disse sager afsluttet med pålæggelse af bødestraf, hvor niveauet ligger omkring 10-15.000 DKK, hvilket er meget lavt i forhold til, hvordan vildledning straffes ved overtrædelse af markedsføringslovens vildledningsforbud.

\subsection{Konklusion vedrørende Danmark}

Når man gennemgår den lovgivning, der regulerer markedsføringen i Danmark, finder man forbudet mod vildledning gentaget mange steder. 
Det findes således både i den generelle lovgivning i form af markedsføringslovens $\S 2$ og i en lang række af særlovgivningens regler, der regulerer markedsføring, mærkning og andre forhold vedrørende specifikke produkter. Generalklausulen i Markedsføringslovens § 1 er derimod enestående i markedsføringsretlig sammenhæng, og hvor særlovgivningens regler om vildledning derfor må anses for at være lex specialis, er generalklausulen vedrørende god markedsføringsskik gældende som den relevante regel for al markedsføring.

Tilsyn med overholdelse af disse regler føres dels af Forbrugerombudsmanden, der har den overordnede markedsføringsmæssige erfaring og indsigt, dels af specialmyndigheder, der har særlig indsigt og ekspertise på hver deres felt inden for specialområdernes produkter. Disse myndigheder har således konkurrerende kompetence, hvilket gør, at samspillet vedrørende håndhævelse af vildledningsforbudene forekommer noget uafklaret i Danmark. Forbrugerombudsmanden tilser ikke markedsføringen på specialområderne, da det ud fra et lex specialis synspunkter er særlovgivningen og de dertil knyttede myndigheder, der er rette myndighed herfor og som har den særlige, faglige indsigt, der er knyttet til området, medens specialmyndighedernes fokus og anvendelse af ressourcer er rettet mere mod overholdelse af særlovenes mere tekniske krav og mindre mod de markedsføringsmæssige metoder til afsætning af produkterne.

Bødeniveauet for overtrcedelse af markedsføringslovens vildledningsforbud er i de senere år steget, og ligger nu i en størrelsesorden, der som en grov hovedregel som udgangspunkt udregnes efter den fortjeneste, der er opnået eller tilsigtet med den vildledende markedsføring (eller to gange markedsføringsudgiften), og der ses bøder i størrelsen 125.000 DKK, 250.000 DKK, 400.000 DKK, 1 mill. DKK og 2 mill. DKK

Scrlovgivningens bødeniveau ligger væsentligt lavere end det, der er lagt efter markedsføringsloven. Det ligger formentlig omkring 5.00020.000 DKK med 50.000 DKK som den højeste bøde givet for overtrædelse af fødevareloven. Bøderne på specialområderne er i høj grad »standardbøder « med en »normalbøde« på 10.000 DKK

Samlende og lidt sat på spidsen kunne man konkludere, at det i Danmark næppe er hverken regler eller myndigheder, der mangler for at kunne opnå sammenhæng og konsistens vedrørende sanktioneringen af vildledende markedsføring. En højere grad af afklaring af problemerne omkring konkurrerende tilsynskompetence og af myndighedernes rollefordeling og et mere nært samarbejde med orientering myndighederne imellem kunne medvirke til, at den store ulighed i bødeniveauet kunne udlignes. Det samarbejde, der allerede nu findes mellem de relevante myndigheder bør formentlig intensiveres, og praksis og erfaringsudveksling bør koordineres. De relevante myndigheders fokus bør endvidere i højere grad rettes imod kontrollen af overholdelse af reglerne om vildledende markedsføring, selv om dette naturligt vurderes som en mindre 
påtrængende opgave i den ressourcemæssige fordeling af opgaver, der skal sikre forbrugernes sundhed og sikkerhed.

Den påfaldende forskel i bødeniveauet mellem særlovgivningsovertrædelser og overtrædelse af markedsføringsloven bør nivelleres, og det meget lave niveau for bøder på særlovgivningens område må nok siges at høre en anden tid til. Der bør næppe være forskel i sanktioneringen af vildledende markedsføring afhængig af, om vildledningen er foretaget inden for særlovgivningens område eller inden for markedsføringslovens generelle regulering, og bøder bør være af en størrelsesorden så det ikke blot kan indregnes som en lille driftsomkostning.

Når dette er sagt, skal det dog også bemærkes, at det ikke er bødeniveauet alene, der bestemmer, om en lovgivning overholdes. Bødeelementet udgør kun en mindre del af løsningen af problemerne vedrørende vildledende markedsføring. Kontrollens effektivitet, forhandlinger mellem myndigheder og erhvervsdrivende, påbud og forbud, samt de erhvervsdrivendes respekt for presse- og forbrugerreaktioner har formentlig en væsentlig rolle i håndhævelsen af forbudene. 



\section{Island}

\subsection{Generel regulering af vildledning}

\subsubsection{Lov om tilsyn med uretmæessig markedsføring m.m.}

Den 1. juli 2005 blev Konkurrencelovens kapitel 6 og 7 ophævet og erstattet af Lov om tilsyn med uretmæssig markedsføring og markedets gennemsigtighed (lög um eftirlit með óréttmætum viðskiptaháttum og gagnsæi markaðarins), jf. lov nr. 57/2005. Konkurrencedirektoratet - i daværende form - blev nedlagt og erstattet bl. a. af Neytendastofa, herefter på dansk Forbrugermyndigheden ifølge Lov om Forbrugermyndigheden og forbrugernes talsmand (lög um Neytendastofa og talsmann neytenda), lov nr. 62/2005. Forbrugermyndigheden er en ny offentlig myndighed fremkommet ved sammenlægning af den tidligere forbrugerafdeling fra Konkurrencedirektoratet og af Justervæsenet som samtidigt blev nedlagt og dennes myndighedsopgaver lagt til Forbrugermyndigheden, s.s. tilsyn med målesikkerhed, produktsikkerhed, el-sikkerhed, legal metrologi, m.m.

Der blev samtidig oprettet et særligt uafhængigt embede som Forbrugertalsmand, der skal varetage forbrugernes generelle interesser og er initiativtagende mod erhvervsdrivende og lovforvaltningen med betænkninger om forbedringer, m.m. Embedet har sit sæde og bopæl inden for Forbrugermyndighedens kontor som herudover varetager den daglige sekretariatsfunktion og bidrager til forberedelse af sager for Forbrugertalsmanden efter aftale.

Forbrugermyndigheden hører under Handelsministeriet og skal bl.a. sikre overholdelse af kravene til forbrugersikkerhed og forbrugerinteresser i markedsføringen samt sikre overvågning af anden lovgivning som den har tilsyn med.

Artikel 1 i lov nr. 62/2005 fastlægger, at Forbrugermyndigheden er en uafhængig, statslig myndighed, der skal arbejde administrativt på området for forbrugerinteresser, produktsikkerhed, offentlig markedskontrol, målesikkerhed, el-sikkerhed, legal metrologi m.m. Loven henlægger endvidere det offentligretlige tilsyn med de civilretlige forbrugerbeskyttelseslove under Forbrugermyndigheden; bl.a. lov om forbrugerkreditaftaler, lov om dørsalg og fjernsalg, pakkerejseloven, prismærkninger m.fl. Forbrugermyndigheden skal endvidere sørge for implementeringen af og føre tilsyn med lov nr. 57/2005 om tilsyn med uretmæssig markedsføring m.m. Overordnet skal Forbrugermyndigheden arbejde frem mod en udformning af en forbrugerpolitik, ligesom Forbrugermyndigheden skal 
gå i spidsen for udførelsen af undersøgelser på dette felt samt indsamle, formidle og offentliggøre informationer på forbrugerområdet til forbrugere og erhvervslivet.

Lov om tilsyn med uretmæssig markedsføring gælder for enhver form for erhvervsvirksomhed, uanset om sådan virksomhed drives af enkeltpersoner, juridiske personer, i offentligt regi eller på anden måde, jf. lovens artikel 1. Loven gælder for aftaler, betingelser og aktiviteter, der har eller tilsigter at have markedsmæssig virkning i Island. Forbrugermyndigheden kan føre tilsyn med al markedsføring, men på de områder, hvor der findes en særlig lovgivning - som f.eks. fødevarelovgivningen og lægemiddellovgivningen - er det de tilsvarende myndigheder, der foretager tilsynet.

Ifølge lovens artikel 5 er det i sådan erhvervsmæssigt virke ikke tilladt at handle i modstrid med god handelsskik eller i strid med forbrugernes interesser.

Loven indeholder i artikel 6 forbud mod at give ukorrekt, utilstrækkelig eller vildledende oplysninger i reklamer eller på anden måde, som er egnet til at påvirke efterspørgsel eller udbud af varer, fast ejendom, tjenesteydelser eller andre formuegoder. Reklamer og andre forretningsmetoder må ikke være urimelige overfor andre erhvervsdrivende eller forbrugere på grund af deres form, eller fordi de inddrager uvedkommende forhold, jf. artikel 6, stk. 2.

Sammenlignende reklame er reguleret i lovens art. 7. Artikel 8 bestemmer, at markedsføring, der er rettet mod islandske forbrugere skal ske på islandsk, og at al markedsføring skal udformes således, at der ikke er tvivl om, at der er tale om markedsføring. Skjult reklame er således også forbudt i Island.

Artikel 9 indeholder krav om, at der skal gives tilstrækkelige oplysninger ved aftalers indgåelse, særligt med hensyn til det købtes anvendelse, holdbarhed, vedligeholdelse, risikofaktorer ved det købte m.v. Disse oplysninger skal gives på islandsk, engelsk eller et af de skandinaviske sprog (dog ikke finsk).

Loven indeholder herudover regler om garanti, særlige markedsføringsmetoder, regulering af markedsføring overfor børn og unge m.v.

Forbrugertalsmanden (jf. ovenfor) overvåger det generelle forbrugerinteresse og der med at de erhvervsdrivende overholder regler som beskytter forbrugerne inklusive regler om uretmæssig markedsføring. Forbrugertalsmanden rejser opmærksomhed, når han finder, at forbrugernes rettigheder og interesser er blevet tilsidesat. Forbrugertalsmanden kan endvidere udstede betænkninger med forslag til forbedringer, ligesom han skal udarbejde forslag til forbedringer af love og administrative forskrifter med relation til forbrugerområdet.

Forbrugerombudsmanden kan handle på eget initiativ eller efter foredrag, ærinde, klager eller lign. fra enkelte forbrugere. Alle forbrugere er 
berettigede til at indbringe klager for Forbrugertalsmanden, men han beslutter selv, om han finder anledning til at viderebehandle sagen.

Overtrædelse af forbudet mod vildledning jf. artikel 6, og af reglerne om sammenlignende reklame jf. artikel 7, eller af regler udstedt med hjemmel i artikel 16 vedrørende lovens artikel 5-9, er sanktioneret ved administrativ bøde. Forbrugermyndigheden kan pålægge erhvervsdrivende administrative bøder, der kan andrage op til 10 millioner ISK. (1 DKK svarer ca. til 10 ISK.) Hvis en beslutning (om påbud eller forbud), der er blevet truffet af Forbrugermyndigheden på grund af den erhvervsdrivendes overtrædelse af loven, ikke efterkommes af den erhvervsdrivende, kan Forbrugermyndigheden beslutte at pålægge dagbøder, indtil den omhandlede beslutning er efterkommet.

I tilfælde af grov overtrædelse af lov om tilsyn med uretmæssig markedsføring og markedets gennemsigtighed kan der idømmes bøde eller fængsel i op til 6 måneder, jf. lovens artikel 26.

Forbrugermyndighedens beslutninger kan ankes til Ankenævn for forbrugerspørgsmål, jf. 4.1.2 nedenfor.

\subsubsection{Praksis vedrørende lov om tilsyn med uretmcessig forretnings-føring m.m.}

Loven om uretmæssig markedsføring anvendes på vildledende markedsføring uanset hvilket produkt, der reklameres for. Der findes således sager om vildledende markedsføring af fødevarer, kosttilskud, helseprodukter, kosmetik m.m. De fleste af sagerne afgøres med påbud, og hvis den erhvervsdrivende standser den vildledende markedsføring, går sagen ikke videre. Hvis den erhvervsdrivende ikke ændrer eller ophører med den vildledende markedsføring, nedlægges der forbud, der kan kombineres med bøde.

Hos den nye Forbrugermyndighed findes kun nogle beslutninger på grund af myndighedens tilsyn med lov om uretmæssig markedsføringsskik, da denne nye myndighed er meget nylig oprettet. Loven er trådt $\mathrm{i}$ kraft pr. 1. juli 2005 med meget kort tid til at omstille myndighederne som blev lagt sammen og implementere loven. Formålet med denne lov er bl.a. at styrke forbrugernes retsbeskyttelse overfor uretmæssig markedsføring, Den praksis, der måtte findes efter den tidligere lovgivning (konkurrenceloven), vil således kunne anvendes som en minimumsstandard for kommende praksis. Langt de fleste sager sluttes med påbud og kun i ca. $10 \%$ af sagerne nedlægges der forbud, og af disse er der kun ganske få, der ender med, at der bliver fastlagt bøde.

I 2002 begyndte først fastlæggelse af administrative bøder i Island med hjemmel i straffebestemmelser i konkurrenceloven. Bøder bliver nu fastlagt af Forbrugermyndigheden med henvisning til artikel 22 i lov om uretmæssig markedsføring. Hvis den erhvervsdrivende ikke vedtager Forbrugermyndighedens bødeforlæg, kan sagen ankes i medfør af artikel 
4 i lov nr. 62/2005 til Ankenævnet for forbrugerspørgsmål. Herfra kan sagen indankes til domstolene, jf. lovens artikel 25.

Følgende er en udtømmende oversigt over offentliggjort praksis, hvor der er givet bøder på grundlag af konkurrenceloven og lov om uretmæssig markedsføring, hvor sagen handlede om vildledende markedsføring:

Der har ikke været en eneste dom offentliggjort vedrørende vildledende markedsføring siden 1993, hvor Højesteret afsagde dom i en sag om vildledende brug af ordet gratis, hvor forbrugerne måtte betale for andre ting for at få den ting, der var "gratis« (Højesterets dom nr. 347/1990. Sagen er indbragt for domstolene i 1990, Myndsýn gegn samkeppnisráði).

Konkurrencerådets beslutninger nr. 9/2002, 10/2002, 11/2002, 12/2002 og 26/2002 er alle vedrørende sager, hvor rejsebureauer og flyselskabet Icelandair blev pålagt bøder for overtrædelse af forbudet mod vildledende markedsføring (den nuværende markedsføringslovs artikel 6) ved ikke at indregne passagerafgift i den reklamerede pris for flybilletter. Bøden var på ca. 30-40.000 DKK for hvert firma. To af rejsebureauerne og flyselskabet ankede til Ankenævnet, der i afgørelserne nr. 7/2002, 9/2002 og 10/2002 stadfæstede Konkurrencerådets beslutninger.

En virksomhed blev pålagt bøde ved beslutning 30/2002 for at fortsætte med at anføre vildledende oplysninger i brochurer, efter at Konkurrencedirektoratet havde forbudt påstanden »den mest populære« om trailere af Palomino-typen (teltvogne), da dette ikke blev dokumenteret.

I januar 2005 accepterede et lavprisflyselskab Iceland Express en bøde på 20.000 DKK for ikke at medregne passagerafgiften i den pris, der blev reklameret med, jf. de sager, der er nævnt ovenfor.

Et telekommunikationsfirma accepterede i juni 2005 en bøde på 20.000 DKK for vildledende brug af ordet "gratis « i reklamer i strid med Konkurrencerådets beslutning nr. 27/2004 vedrørende overtrædelse af forbudet mod vildledning (jf. nu artikel 6 i lov nr. 57/2005)

I Forbrugermyndighedens beslutning nr. 1/2006 blev et supermarked Nóatún pålagt en bøde på 50.000 DKK for ikke at kunne bevise påstanden »bedst i fisk« Påstanden blev bedømt som vildledende i medfør af artikel 6 og 7 i lov nr. 57/2005, om tilsyn med uretmæssig markedsføring m.m. Forbrugermyndighedens beslutning i denne sag blev henvist og bekræftet af Ankenævn for forbrugerspørgsmål.

\subsection{Særlovgivningen}

\subsubsection{Fødevarer, kosttilskud, naturlcegemidler, alkohol og tobak}

Fødevareloven (Lög um matvæli), jf. Lov nr. 93/1995 skal, så vidt det er muligt, sikre kvalitet, sikkerhed og sundhed i fødevarer, og at fødevarers mærkning og andre informationer om dem er korrekte og tilstrækkelige, 
jf. lovens artikel 1. Fødevareloven gælder produktion og distribution af fødevarer.

Fødevareloven indeholder i artikel 3 en generalklausul, hvorefter produktion og distribution af fødevarer skal udføres på en sådan måde, at det ikke vil skade sundheden, ligesom handel med fødevarer ikke må foretages under brug af vildledende information.

Loven hører overordnet under Miljøministeren, men særlige områder kan være underlagt andre ministre i medfør af særlovgivning, jf. artikel 5. Miljø- og fødevarestyrelsen skal rådgive ministeren, jf. artikel 5.

Overvågningen af fødevareområdet foretages på kommunalt plan af sundhedsmyndighederne/fødevareregionerne, der kan suspendere eller begrænse produktion og distribution eventuelt standse denne, såfremt der er grund til at antage, at fødevarer ikke opfylder kravene i Fødevareloven eller i bekendtgørelser udstedt i medfør af denne.

Fødevarelovens kapitel IV omhandler produktion og distribution, og i dette kapitel findes bl.a. artikel 11, der bestemmer, at fødevarer ikke må udbydes til salg eller distribueres på en sådan måde, at køberen kan blive vildledt med hensyn til varens oprindelse, art, kvalitet, sammensætning, mængde, beskaffenhed eller virkning.

Ministeren skal i henhold til artikel 11 fastsætte regler for, hvorledes fødevarer må udbydes i salg eller på anden måde distribueres på en måde, der indikerer, at produktet er særligt egnet for specifikke grupper af forbrugere med hensyn til alder, sygdomme eller andre omstændigheder.

Den ansvarlige minister kan endvidere foranledige iværksættelse af nødvendige sikkerhedsforanstaltninger og forebyggende forholdsregler i tilfælde af, at det vurderes, at der er fare for, at fødevarer kan foranledige alvorlig skade på sundheden, jf. artikel 28. Ministeren skal i fornødent omfang konsultere andre relevante myndigheder, inden der iværksættes sådanne foranstaltninger. Vildledende reklame vedrørende fødevarer kan tænkes at kunne forårsage risiko for sådan alvorlig skade på sundheden. Det vil dog formentlig være sjældent, at sådanne indgreb sættes i værk foranlediget af vildledende reklame. Ligeledes kan tilsynsmyndighedernes anvendelse af muligheden for at standse produktion og distribution tænkes anvendt i tilfælde, hvor vildledning kan føre til risiko for skade på forbrugernes sundhed, jf. artikel 29. En producent eller distributør, der dømmes for overtrædelse af loven, skal betale de fulde omkostninger ved indsamling af prøve, testning heraf samt andre omkostninger som følge af overtrædelsen.

Herudover skal reglerne i lov om sundhed og miljøbeskyttelse (lög um hollustuhætti og mengunarvarnir), jf. lov nr. 7/1998 følges vedrørende procedurer, sagsanlæg og straf.

Kosttilskud er reguleret af bekendtgørelsen nr. 624/2004 (reglugerð um fæðubótarefni), som implementerer direktiv 2002/46/EF om indbyrdes tilnærmelse af medlemsstaternes lovgivninger om kosttilskud. Efter denne bekendtgørelse er det ikke tilladt i mærkning, præsentationsmåde 
eller reklamer at anføre, at kosttilskud kan forebygge, behandle eller helbrede sygdomme hos mennesker eller henvise til sådanne egenskaber, og produktet skal mærkes med »kosttilskud «, jf. bekendtgørelsens artikel 5 .

Alle former for fødevarer, som er beregnet på forbrugere, er underlagt bekendtgørelse nr. 503/2005 om mærkning af fødevarer (reglugerð um merkingu matvæla) og del IV i bekendtgørelse nr. 588/1993 om mærkning, reklamering og markedsføring af fødevarer (reglugerð um merkingu, auglýsingu og kynningu matvæla). Disse bekendtgørelser fastlægger en lang række krav til mærkning og deklaration af fødevarer. Det er efter $\S 5$ et krav, at mærkning skal være klar og tydelig og må ikke være vildledende vedrørende fødevarens indhold, type, vægt, oprindelse m.v., desuden forbydes der henvisning til egenskaber eller virkninger, som fødevaren ikke er i besiddelse af. Det er endvidere ikke tilladt at henvise til virkning eller forebyggelse af sygdomme hos mennesker eller til, at fødevaren har medicinsk virkning. Dog er visse specielle fødevarer og naturligt kildevand undtaget fra denne regel.

Sundhedsmyndighederne (heilbrigðisnefndir) under Miljø- og fødevarestyrelsen overvåger overholdelse af bekendtgørelsens regler og krav. Hvis et kosttilskud er mærket eller annonceres eller på anden måde markedsføres ved anprisninger om dets indhold, skal producenten eller importøren kunne præsentere tests, der viser, at disse anprisninger er korrekte.

Salg og markedsføring af leegemidler er reguleret ved lægemiddelloven (lyfjalög), jf. lov nr. 93/1994, men også i Island er naturlægemidler undtaget fra lægemiddellovgivningen og underlagt fødevarelovgivningen som beskrevet ovenfor.

Kosmetik er reguleret af bekendtgørelse nr. 748/2003 om kosmetiske produkter (reglugerð um snyrtivörur) i overensstemmelse med EUreglerne herom.

Salget af alkohol er reguleret af alkohollovgivningen (áfengislög), jf. lov nr. 75/1998 og al markedsføring af alkohol (over 2,25 \% alkoholprocent) er forbudt jf. artikel 20. Overtrædelse af loven og regler udstedt i henhold til den straffes med bøde eller fængsel i op til 6 år, jf. artikel 27. Bøde skal tage hensyn til alkoholafgifternes størrelse, men niveau er ikke angivet.

Tobak er reguleret af lov om forebyggelse af brug af tobak (lög um tóbaksvarnir), jf. lov nr. 6/2002) og al markedsføring af tobak er forbudt jf. artikel 7.

\subsubsection{Praksis vedrørende scerlovgivningen}

Da sundhedsmyndighederne/fødevareregionerne alle er selvstændige organer, findes der ikke nogen samlet database at undersøge. Reykjavik har af naturlige årsager flest sager, og ifølge myndighederne i Reykjavik behandles der mange sager vedrørende vildledende og forkerte oplysnin- 
ger og manglende mærkning af bl.a. fødevarer. De fleste konflikter løses med påbud, men i nogle sager er det nødvendigt at suspendere eller begrænse produktion og distribution, eventuelt at standse denne. Da sundhedsmyndighederne ikke kan udstede administrative bøder, er sagsgangen, at sundhedsmyndighederne indklager virksomheden til politiet, der så skal viderebehandle sagen, men anklagemyndigheden har endnu aldrig rejst tiltale for overtrædelse af vildledningsforbudene, uanset at sundhedsmyndighederne antager, at dette burde have været gjort i nogle tilfælde.

Konkurrencedirektoratet behandlede mange sager vedrørende kosttilskud i årene før 2004, hvor sundhedsanprisninger for kosttilskud blev reklameret kraftigt vedrørende f.eks. hvidløg, ginseng m.v. De fleste sager sluttede med påbud eller forbud på grund af vildledende markedsføring, da virksomhederne ikke kunne bevise anprisningernes sandhed, men der blev ikke pålagt nogen bøder. På dette tidspunkt havde Lægemiddelstyrelsen ikke mange muligheder for at stoppe annoncer med sundhedsanprisninger, og derfor anvendtes konkurrenceloven i stedet dvs. de nuværende artikler 5, 6 og 7 i nugældende lov nr. 57/2005 om tilsyn med uretmæssig markedsføring m.m. I 2004 kom bekendtgørelse nr. 624/2004 om kosttilskud, hvorefter artikel 12 overfører fødevarelovens artikel 30 bestemmer vedrørende tvangsmidler og kompetence. Vedrørende straf for overtrædelse af vildledningsforbudene gælder artikel 31 i fødevareloven og lov om sundhed og miljøværn. Der er dog ikke pålagt bøder heller efter 2004, men fødevaremyndighederne har givet instrukser/påbud ifølge bekendtgørelsen.

Lægemiddelstyrelsen har i 2002 fået hjemmel til at udstede dagbøder for overtrædelse af styrelsens påbud (5.000 DKK pr. dag, jf. artikel 47 i lov nr. 93/1994). Dette gælder også for naturlcegemidler, der henhører under lægemiddelloven. Sagsgangen ved pålæggelse af bøder er den samme som for sundhedsmyndighederne, således at den relevante myndighed også her skal klage til politiet, der herefter skal viderebehandle sagen. Dette system er meget tungt og virker derfor som en stærkt hæmmende faktor på gennemførelsen af en egentlig retsforfølgelse af de virksomheder, der overtræder gældende regler og forbud. Der tiltrænges således et mere effektivt system, hvor de administrative myndigheder får mulighed for at pålægge bøder for vildledende markedsføring, således som det nu er blevet indført for Forbrugermyndigheden på de områder, der hører under dennes tilsynskompetence.

Ifølge alkoholloven (áfensigslög), jf. lov nr. 75/1998 artikel 20 er al reklamering med alkohol med en alkoholprocent over 2,25 forbudt. Vildledende markedsføring vedrørende alkohol er ikke behandlet for domstolene. Inden at administration af lov om tilsyn med uretmæssig markedsføring blev flyttet ifølge lovændringer i 2005 til Forbrugermyndigheden havde Konkurrencedirektoratet behandlet nogle sager. Forbrugermyndigheden har på nuværende tidspunkt behandlet en enkelt sag, 
hvor øl med en alkoholprocent over 2,25 blev markedsført som »let øl«, dvs. at der i annoncen står $0 \%$, selv om øllet reelt indeholder $5 \%$ alkohol. Det er blevet fastslået, at det er vildledende at markedsføre stærkt øl som let øl jf. artikel 6 i lov om markedsføring. De fleste sager blev afgjort med påbud, men nogle firmaer kunne bevise, at øllet eksisterede i flasker med samme udseende også som let øl.

Markedsføring af tobaksvarer er reguleret af lov om forebyggelse af brug af tobak (lög um tóbaksvarnir, lov nr. 6/2002), hvorefter al reklamering med tobaksvarer er forbudt, jf. artikel 7. Overtrædelse af dette forbud straffes med bøde eller ved grove overtrædelser med fængsel i op til 2 år, jf. artikel 19. der foreligger intet om bødeniveauet herfor, idet vildledende markedsføring af tobaksvarer ikke har været behandlet ved domstolene.

\subsection{Konklusion vedrørende Island}

Forbrugermyndigheden kan føre tilsyn med al markedsføring, men det vil fortsat i Island være således, at hvor der findes særlovgivning og dertil hørende særmyndigheder, vil tilsynet skulle varetages af disse særmyndigheder.

Det kan generelt konkluderes, at der ikke gives mange bøder for vildledende markedsføring i Island. Også i Island er det forhandlinger, påbud og forbud, der er de mest anvendte styringsredskaber i overvågningen af de erhvervsdrivendes markedsføring.

Det bødeniveau, der er i de få sager, det har været muligt at finde om bøde for overtrædelse af vildledningsforbudet, er meget lavt, og svarer vel nogenlunde til en enkelt ret lille annonce i et tidsskrift eller en avis. Det kan næppe i sig selv have nogen præventiv effekt. 


\section{Norge}

\subsection{Generel regulering af vildledning}

\subsubsection{Markedsføringsloven og Forbrukerombudet}

Markedsføringsloven (lov nr. 47 af 16. juni 1972 med senere ændringer) regulerer markedsføring foretaget i privatvirksomhed og i offentlig virksomhed, der kan sidestilles hermed. Markedsføringsloven indeholder i § 1 den norske markedsføringslovs hovedbestemmelse i form af en generalklausul, der indeholder et forbud mod at foretage markedsføringshandlinger, der strider mod god forretningsskik næringsdrivende imellem, eller som er urimelig i forhold til forbrugere eller som for øvrigt strider mod god markedsføringsskik.

Det vil også i Norge kunne være i strid med generalklausulen at anvende urigtige, vildledende eller urimeligt mangelfulde angivelser eller markedsføringsmetoder.

I lovens $\S \S 2$ og 3 findes forbud mod vildledende markedsføring og utilstrækkelig vejledning.

Markedsføringslovens § 2, stk. 1 og 2, lyder: »Det er forbudt i næringsvirksomhed at anvende urigtig eller af anden grund vildledende fremstilling som er egnet til at påvirke efterspørgselen efter eller udbud af varer, tjenester eller andre ydelser.

Det samme gælder enhver anden fremgangsmåde som kan have sådan betydning for efterspørgsel eller tilbud, såfremt den gennem sin udformning eller på grund af omstændigheder ellers er egnet til at vildlede forbrugere«.

$\S 2$ er blandt de regler, der anvendes mest af markedsføringslovens bestemmelser, og den fastlægger et »sandhedsprincip« i norsk markedsføringsret. Reglen bygger i dag på tillæg til EU-direktiv 84/450/EØF om vildledende reklame.

Markedsføringslovens § 3 lyder: »Det er forbudt i næringsvirksomhed at anvende fremstilling som er egnet til å påvirke efterspørgselen efter eller udbud af varer, tjenester eller andre ydelser, når fremstillingen ikke giver forsvarlig eller tilstrækkelig vejledning eller inddrager uvedkommende forhold, og derfor må anses urimelig.

Det samme gælder enhver anden fremgangsmåde som kan have sådan betydning for efterspørgsel eller udbud, dersom den udnytter forbrugeres mangelfulde erfaring eller kundskaber, og derfor må anses urimelig«. 
$\S \S 2$ og 3 kom ind i Markedsføringslovgivningen i 1966 og var et ønske om at gøre loven strengere end hidtil og pålægge de erhvervsdrivende et krav om oprigtighed og en aktiv oplysningspligt.

Alle brancher og alle typer erhvervsvirksomhed er omfattet af denne generelle regulering, ligesom også alle led i markedsføringen er omfattet, lige fra idé stadiet til inkasso og eftersalgsservice.

Sanktioner ved overtrædelse af Markedsføringsloven er i Norge nedlæggelse af påbud og forbud med samtidigt bestemmelse om tvangsgebyr, som forfalder ved manglende overholdelse af reglerne samt straf i form af bøde eller fængsel i grove tilfælde.

Markedsføringslovens $\S 16$ bestemmer, at overtrædelse af Markedsrådets eller Forbrukerombudets bestemmelser (vedtak) over tvangsgebyr efter lovens $\S \S 12$ og 14 vedrørende markedsføring i strid med $\S \S 1-5$ eller urimelige aftalevilkår som nævnt i § 9 a udløser et tvangsgebyr, som skal betales af den, som bestemmelsen om tvangsgebyr retter sig mod, eller som medvirker til, at en anden foretager den handling, bestemmelsen retter sig imod.

Den, der forsætligt overtræder lovens $\S \S 2-9$ eller vedtak efter markedsføringsloven, straffes med bøde, fængsel i op til 6 måneder eller begge dele, medmindre strengere stof er forskyldt efter anden lovgivning. Uagtsom overtrædelse af $\S \S 2,2$ a, første led, og 3 straffes på samme måde, jf. § 17.

Markedsrådet og Forbrukerombudet skal medvirke til gennemførelsen af bestemmelserne i markedsføringsloven, jf. dens $\S 10$.

Markedsrådet er et forvaltningsorgan, der er bredt sammensat og består af 9 medlemmer. Markedsrådet kan træffe bestemmelse om forbud mod ulovlig markedsføring og påbud til overholdelse heraf, når dette tilsiges ud fra hensynet til forbrugerne, og Rådet kan også forbyde vilkår i standardkontrakter, som er urimelige over for forbrugerne.

Markedsrådet behandler enkelte af de sager, som Forbrugerombudsmanden tager op. De fleste af de sager Forbrugerombudsmanden behandler, løses gennem forhandlinger, hvor den erhvervsdrivende som oftest indretter sig efter Forbrugerombudsmandens synspunkter.

Markedsrådets afgørelser kan ikke indbringes for anden administrativ myndighed, men de kan indbringes for domstolene.

Forbrugerombudsmanden skal, ud fra hensynet til forbrugerne, føre tilsyn med, at markedsføring af varer og tjenester sker i overensstemmelse med markedsføringsloven. Forbrugerombudsmanden har også tilsynet med dele af kringkastingsloven og kreditkøbsloven. Forbrugerombudsmanden fører endvidere tilsyn med forskrift om fibermærkning, forskrift om vedligeholdelsesmærkning af tekstilprodukter samt forskrift om markedsføring af alternativ behandling af sygdom.

Forbrugerombudsmanden skal søge at påvirke alle næringsdrivende til at indrette deres virksomhed i overensstemmelse med disse regler, jf. markedsføringslovens $\S 13$. 
De fleste sager tages op af Forbrugerombudsmanden på grundlag af klager fra forbrugerne og erhvervsdrivende, men Forbrugerombudsmanden kan også tage en sag op på eget initiativ. Forbrugerombudsmanden søger gennem forhandlinger med de erhvervsdrivende at nå frem til frivillige ordninger, men såfremt en sådan ordning ikke kan nås, kan Forbrugerombudsmanden eller den erhvervsdrivende bringe sagen for Markedsrådet. Forbrugerombudsmanden kan forelægge principielle sager for Markedsrådet, selv om der ikke foreligger nogen tvist med den erhvervsdrivende.

\subsubsection{Praksis vedrørende overtrcedelse af markedsføringslovens vildledningsforbud}

De sager, der findes, vedrørende overtrædelse af vildledningsforbudet, omfatter ofte overtrædelse af andre regler i markedsføringslovgivningen, hvorfor det kan være vanskeligt at få overblik over, hvilket niveau bødestørrelsen for vildledning uden andre overtrædelser ligger på. Ved vurderingen af strafniveauet inkluderes også størrelsen af tvangsgebyr, idet disse i sanktionsøjemed må kunne sidestilles.

Fra praksis kan nævnes følgende sager: En af de seneste sager angår vildledende markedsføring vedrørende prisreklame ved at give "prisafslag « på håndknyttede tæpper. Markedsrådet har fastslået, at det er vildledende at annoncere med prisafslag på ægte tæpper, såfremt man ikke kan dokumentere de »før priser «, som man sammenligner prisafslaget med. Markedsrådet har fastlagt fortsat overtrædelse af disse retningslinjer til et tvangsgebyr på 200.000 NOK til hver af en tæppeforretnings to indehavere.

I en afgørelse af en sag mod et elektromarked (MR-sag 04/04), som anvendte udtrykkene »altid billigst « og »150 \% prisgaranti«, ansås disse udtryk for vildledende markedsføring og utilstrækkelig vejledning i strid med markedsføringslovens $\S \S 2$ og 3. Denne overtrædelse udløste et tvangsgebyr på 500.000 NOK i medfør af markedsføringslovens § 12, jf. $\S \S 2$ og 3 og forskrift om sammenlignende reklame $\S 1$.

I en sag mod et lottofirma (MR-sag 8/03) bestemte Markedsrådet, at udtrykkene "gevinstgaranti «, "gratis tipning for $1.000 \mathrm{DKK}$ « samt anvendelse af tilgift i form af skrabelodder var markedsføring i strid med lovens $\S \S 1,2,4$ og 5 og fastsatte et tvangsgebyr på 400.000 NOK med henvisning til, at markedsføringen havde berørt et stort antal forbrugere, og at der havde været mange klager.

I MR-sag 02/04 pålagdes et firma i medfør af markedsføringslovens § 12, jf. §§ 2 og 3, tvangsgebyr på 300.000 NOK, medens dets indehaver blev pålagt et tvangsgebyr på 100.000 NOK for anvendelse af vildledende angivelser om priser og givne rabatters størrelse. Der var anvendt udtryk som » $\div 30 \%$ », »indtil $\div 40 \%$ » og »Nu $30 \%$ », uden at rigtigheden heraf kunne dokumenteres. 
I Markedsrådets sag 8/00 fastlagdes et tvangsgebyr på 400.000 NOK for en stærkt vildledende markedsføring af postordrevarer, hvor de tilkendte varers værdi langt fra stod i forhold til de forventninger, firmaet havde skabt hos forbrugerne, ligesom firmaet i strid med sandheden anførte, at modtagerne af et markedsføringsmateriale var »eksklusivt udvalgte« forbrugere.

\subsubsection{Konklusion vedrørende bødeniveauet for overtrcedelse af markedsføringslovens vildledningsforbud}

Det kan med udgangspunkt i ovennævnte sager konkluderes, at overtrædelse af markedsføringslovens regler om vildledning sanktioneres med tvangsgebyrer/bøder ligger på et temmelig højt niveau. Der er således givet bøder på 100.000 NOK, 200.000 NOK, 300.000 NOK, 400.000 NOK og 500.000 NOK i sager, hvor overtrædelsen har været grov og omfattende.

\subsection{Fødevarer}

\subsubsection{Matloven og Mattilsynet}

Som tidligere nævnt er fødevareområdet reguleret af fælles EU-regler, hvorfor der i vid udstrækning gælder de samme regler i alle de nordiske lande, idet også Norges retlige regulering er tæt tilpasset EUreguleringen.

Fødevarer er i Norge reguleret af lov nr. 124 af 19. december 2003 om matproduksjon og mattrygghet m.v. (matloven). Formålet med loven er at sikre sundhedsmæssigt trygge næringsmidler og at fremme sundhed, kvalitet og forbrugerhensyn langs hele produktionskæden, samt at varetage miljømæssig produktion, jf. lovens § 1 .

Matlovens § 10 vedrørende mærkning, præsentation og reklame lyder: »Virksomheden skal sørge for, at mærkning, præsentation, reklame og markedsføring er korrekt, gir modtagere tilstrækkelig information og ikke er egnet til å vildlede.

Kongen kan gi nærmere forskrifter om mærkning, præsentation og reklame, herunder om forbud mod helsemæssig uønsket markedsføring og om vilkår for brug af frivillige mærkningsordninger«.

Hovedprincippet i norsk fødevarelovgivning er således, at reklame og markedsføring skal være korrekt, give modtagerne tilstrækkelig information og ikke være egnet til at vildlede. Dette princip er udmøntet bl.a. i bekendtgørelse (forskrift) om mærkning af næringsmidler (forskrift 21. december $1993 \mathrm{nr}$. 1385), der opstiller principper for mærkning, præsentation og reklame i § 5 . 
Mærkning af fødevarer må herefter ikke vildlede køber med hensyn til fødevarens egenskaber, særligt med hensyn til dens art, identitet, kvalitet, sammensætning, mængde, holdbarhed, oprindelse eller ophavssted, fremstillings- eller produktionsmåde.

Det er ifølge $\S 5$, stk. 2, vedrørende ernæringsanprisninger ikke tilladt at tillægge næringsmidlet virkninger eller egenskaber, det ikke har, eller at give indtryk af, at næringsmidlet har specielle egenskaber, når alle lignende næringsmidler har de samme egenskaber.

Det er heller ikke tilladt at påstå eller give indtryk af, at et næringsmiddel forebygger, helbreder eller lindrer sygdom, sygdomssymptomer eller smerter eller bruge ordene »dietetisk«, »til diett» eller lignende, enten alene eller i tilknytning til andre ord, medmindre dette er tilladt i henhold til bekendtgørelse om fødevarer beregnet til brug ved særlige ernæringsmæssige behov eller bekendtgørelse om udvinding og omsætning m.v. af naturligt mineralvand.

Bestemmelserne i $\S 5$ gælder også reklame og præsentation af næringsmidler, næringsmidlernes eller emballagens form eller udseende, det materiale, der anvendes til emballage, og den måde, næringsmidlerne præsenteres på.

Kosttilskud er særligt reguleret i bekendtgørelse om kosttilskud, hvorefter der i § 6 er opstillet generelle krav om mærkning af kosttilskud. Kosttilskud skal mærkes i overensstemmelse med gældende forskrifter om mærkning af levnedsmidler.

Det er ikke tilladt i mærkning eller markedsføring af kosttilskud at påstå eller give indtryk af, at en balanceret og varieret kost generelt ikke giver tilstrækkelig tilførsel af vitaminer og mineraler, og det er ikke tilladt at påstå eller give indtryk af, at et kosttilskud kan forebygge, helbrede eller lindrer sygdom, sygdomssymptomer og smerter, jf. § 6 , stk. 2 og 3.

Varebetegnelse for produkter, som omfattes af bekendtgørelse om kosttilskud, er »Kosttilskud«, og denne betegnelse er på den anden side forbeholdt produkter, som opfylder betingelserne i bekendtgørelsen. Kosttilskud skal mærkes i overensstemmelse med kravene i bekendtgørelsens $\S 7$, som bl.a. omhandler navnet på de kategorier af næringsstoffer, der kendetegner produktet, anbefalet døgndosis, advarsel mod at indtage mere end den anbefalede døgndosis.

Overtrædelse af bestemmelserne i fødevarelovgivningen kan udløse et tvangsgebyr, såfremt en virksomhed undlader at efterkomme pålæg fra tilsynsmyndighederne inden en fastsat frist. Dette tvangsgebyr kan gives som en engangsbod eller som løbende dagbøder. Bødens størrelse fastsættes under hensyn til, hvor vigtigt det er, at pålægget efterleves, og hvilke omkostninger det antages at medføre, jf. matlovens § 26 .

Forsætlig eller uagtsom overtrædelse af bestemmelserne i matloven eller pålæg i henhold til denne, straffes i medfør af § 28 med bøder eller fængsel op til 1 år eller begge dele, såfremt forholdet ikke er omfattet af 
strengere straffebestemmelser. Også forsøg og medvirken straffes. Under særlig skærpende omstændigheder kan straffen stige til 2 års fængsel.

Matlovens overholdelse administreres på tre niveau af de centrale, de regionale og de lokale mattilsyn. Disse fører tilsyn og kan træffe beslutning om nødvendige pålæg for gennemførelse af lovens bestemmelser, herunder bl.a. forbyde import, eksport og omsætning eller pålægge tilbagetrækning fra markedet, destruktion, mærkning og anden særlig behandling, jf. § 23.

\subsection{2-3 Praksis vedrørende overtrcedelse af fødevarelovgivningens} vildledningsregler og konklusion herpå vedrørende bødeniveauet

Vildledende markedsføring af fødevarer og kosttilskud henhører under Mattilsynet, men det oplyses herfra, at der ikke findes (ret meget) praksis på området, idet kontrollen på dette område af ressourcemæssige årsager er nedprioriteret. Der er dog for tiden indgået aftale med Forbrukerombudet om, at der fra denne myndighed sættes fokus på slankeprodukter. Konklusionen herpå må derfor være, at såfremt Forbrukerombudet ikke fører tilsyn med vildledende markedsføring af levnedsmidler og kosttilskud, bliver et sådant tilsyn slet ikke ført. Se mere herom i afsnit 5.5

\subsection{Alternative behandlinger, naturmedicin, slankemidler, alkohol og tobak}

\subsubsection{Regler og tilsynsmyndigheder}

Kosttilskud er reguleret under levnedsmiddellovgivningen og af forskrift om kosttilskud jf. ovenfor. Grænsen mellem kosttilskud og naturlægemidler er uskarp, men tilsynet med disse produkter er forskelligt, ligesom der er forskel på godkendelsesprocedurer, og hvad der må anføres om produktet.

Der stilles strenge krav til markedsføring af helsekost og naturlægemidler. Påstanden om produkternes gavnlige virkning skal kunne dokumenteres. Det er ikke tilladt at bruge medicinske påstande for andet end egentlige lægemidler (helbreder astma o. lign.), men det er tilladt at fremsætte sundhedsudsagn (godt for maven).

Slankemidler hører under Mattilsynets tilsyn. Der har dog i en periode været en aftale mellem Mattilsynet og Forbrukerombudet om, at Forbrukerombudet skal sætte fokus på reklame for slankemidler, og dette har ført til, at der er blevet rejst flere sager på området.

Alternativ behandling hører under Helsedepartementet, der har udstedt forskrift for markedsføring af alternativ behandling i medfør af lov om alternativ behandling. Kravene til sådan markedsføring er, at den skal give en nøgtern og saglig beskrivelse af virksomhedens art. Det er i medfør af disse retningslinjer ikke tilladt at markedsføre alternativ be- 
handling som »godkendt«, »offentligt registreret« eller på anden måde bruge ordet registreret i kombination med bestemte titler. Det er endvidere ikke tilladt at fremføre påstande om, at en behandlingsform har virkning på konkrete sygdomme eller lidelser, og det må ikke udtales eller antydes, at en alternativ behandler kan helbrede eller behandle en nærmere defineret sygdom eller lidelse som astma, allergier, hjertekarsygdomme, fibromyalgi m.m.. Derimod er det tilladt at give mere generelle beskrivelser i form af udtalelser om, at en behandlingsform benyttes ved »ryg- og nakkeplager«, »stive muskler«, »træthed«, »slaphed « o. lign.

Overtrædelse af denne forskrift er strafsanktioneret, og Forbrukerombudet er tillagt opgaven med at føre tilsyn med, at forskriftens regler overholdes.

Social- og helsedirektoratet fører tilsyn med reklameforbudet i alkoholloven.

Det er også i Norge forbudt at reklamere med tobaksvarer. Markedsføring af tobak er reguleret af tobaksskadeloven (lov nr. 14 af 9. marts 1973), der i § 8 opstiller et forbud mod reklame for tobaksvarer. Forbudet er et tilnærmet totalforbud.

\subsubsection{Praksis vedrørende overtrcedelse af vildledningsforbudet}

Der er i flere tilfælde pålagt store tvangsgebyrer for ulovlig markedsføring af slankemidler, efter at Forbrukerombudet har haft fokus på denne type vildledning. Der kan således nævnes følgende:

Der er den 31. januar 2005 af Forbrukerombudet nedlagt forbud mod Postkjøp A/S’s markedsføring af »Lægens vidunderkur for overvægtige« med udokumenterede påstande om en slankende virkning. Der er knyttet et tvangsgebyr på i alt 450.000 NOK til overtrædelse af forbudet (300.000 NOK til selskabet, dersom det overtræder forbudet, og 150.000 NOK til daglige leder, dersom han overtræder forbudet).

I oktober 2004 blev firmaerne Rett Hjem A/S og Order Service A/S pålagt et tvangsgebyr på i alt 750.000 NOK for brud på forbud mod en slankereklame på Internettet (300.000 NOK til hvert af firmaerne, 150.000 NOK til den daglige leder).

I Norge er al reklame for alkoholholdige drikke forbudt i medfør af lov nr. 27 af 2. juni 1989 (alkoholloven) § 9, stk. 2, der indeholder et absolut forbud mod reklame for alkoholholdige drikkevarer. Dette indebærer, at problemstillinger knyttet til vildledende reklame i høj grad »absorberes « af dette forbud.

Markedsføring af tobak er reguleret af tobaksskadeloven (lov nr. 14 af 9. marts 1973), der i § 8 opstiller et forbud mod reklame for tobaksvarer. Forbudet er et tilnærmet totalforbud. Der føres derfor heller ikke sager om vildledende markedsføring vedrørende tobak i Norge, da det vil være 
selve det ulovlige i overhovedet at reklamere for tobaksvarer, der vil blive skredet ind over for.

\subsubsection{Konklusion vedrørende bødeniveauet for vildledning på sundhedsområdet}

Det bødeniveau, der lægges til grund ved pålæggelse af tvangsgebyrer har i de ovenfor citerede sager om overtrædelse af vildledningsforbudet på disse områder, er som det niveau, der lægges ved overtrædelser bedømt efter markedsføringsloven i øvrigt. Der er således i de seneste tilfælde pålagt bøder på 300.000 NOK til firmaerne plus 150.000 NOK til de ansvarshavende i de omhandlede firmaer. Dette følger formentlig af, at der er sager, der er ført af Forbrukerombudet. Bødeniveauet er ved administrativt pålagte tvangsgebyrer af andre tilsynsmyndigheder kendes ikke, da der ikke er fundet sager offentliggjort herom.

\subsection{Miljøargumenter, kemiske produkter, kosmetik m.v.}

\subsubsection{Regler og tilsynsmyndigheder}

De nordiske forbrugerombudsmænds vejledning om brug af etiske og miljørelaterede påstande i markedsføringen anvendes også i Norge som en minimums standard til vurdering af sådanne påstande efter markedsføringsloven. Herudover kommer eventuelle særlige krav fastsat i speciallovgivningen. Langt de fleste sager på miljøområdet afsluttes efter forhandling mellem Forbrukerombudet og de erhvervsdrivende.

Kosmetikloven regulerer tilsynet med kosmetik og kropsplejeprodukter. Loven giver hjemmel til at udstede forskrifter, hvor der kan gives nærmere bestemmelser om blandt andet markedsføring af kosmetiske produkter. Denne hjemmel er benyttet ved udfærdigelse af forskrift om produktion, import og salg af kosmetik m.v. (kosmetikforskriften).

Kosmetikloven er under revision, men forslaget til ny kosmetiklov er i hovedsagen en videreførelse og lovteknisk opdatering af den gamle lov, dog suppleret med visse nye krav og forskriftshjemler.

Kosmetiklovens $\S 7$ forbyder vildledende markedsføring. Kosmetik og kropsplejeprodukter må således ikke markedsføres under omstændigheder, der er egnet til at vildlede forbrugerne med hensyn til produktets anvendelsesområde eller med hensyn til den risiko, som kan være forbundet med produktet.

Ved salg af kosmetik og kropsplejeprodukter må der ikke benyttes tekst, betegnelser, varemærker, billeder eller andre tegn, som giver produkterne en egenskab, de ikke har.

Mattilsynet fører tilsyn med, at kosmetik og kropsplejeprodukter produceres og sælges i overensstemmelse med gældende regler. Mattilsynets 
kontrol skal forebygge sundhedsskader samt sikre, at produkterne markedsføres på redelig måde, og at salget ikke bryder med dyreetiske bestemmelser.

Mattilsynet fører tilsyn med overholdelse af reglerne og kan træffe beslutning om ophør af ulovlig markedsføring samt beslaglægge markedsførte varer, såfremt disse repræsenterer en sundhedsfare. Tilsynet kan også træffe beslutning om tvangsbøder, hvis frist for opfyldelse af pålæg ikke overholdes.

5.4.2-3 Praksis vedrørende miljøargumenter, kemiske produkter, kosmetik m.v. og konklusion vedrørende bødeniveauet herfor

Det har ikke været muligt at finde praksis vedrørende overtrædelse af speciallovgivningens forbud mod vildledning ved markedsføring af kosmetiske produkter og kropsplejeprodukter

Anvendelse af miljøargumenterne i markedsføringen overvåges af Forbrukerombudet, og der må derfor forventes, at et eventuelt bødeniveau følger det niveau, som gælder for andre overtrædelser af markedsføringsloven.

\subsection{Konklusion vedrørende Norge}

Forbrugerombudet har som udgangspunkt kompetence til at behandle alle typer markedsføring, også hvor der findes speciallovgivning, som virker ved siden af markedsføringsloven. Lex specialis princippet gælder dog og indebærer, at produktspecifikke bestemmelser i speciallovgivningen går forud for markedsføringsloven. Det følger imidlertid af Markedsrådets praksis, at man benytter det såkaldte lovstridsprincip - hvilket vil sige, at markedsføring, som er i strid med regler, som beskytter forbrugerinteresser i anden lovgivning end markedsføringsloven, vil være at anse som brud på generalklausulen i markedsføringslovens § 1 .

Forbrukerombudet har en generel mulighed for at prioritere, hvilke sager det ønsker at behandle, og vil kunne vælge ikke at behandle en klage, der er kommet over en markedsføring. Det følger imidlertid af Markedsrådets praksis, at en sådan nedprioritering vil kunne indklages for Markedsrådet, som kan prøve Forbrukerombudets afgørelse. Der skal derfor meget til, for at Forbrukerombudet vælger ikke at behandle en sag, hvor der findes speciallovgivning, hvis stærke forbrugerhensyn gør sig gældende.

I praksis indgår Forbrukerombudet samarbejdsaftaler med de aktuelle tilsynsorganer på specialområderne. Aftalerne kan gå ud på, at sager oversendes til de enkelte tilsyn, eller at Forbrukerombudet for en afgrænset periode sætter fokus på specielle områder. Som eksempel kan nævnes, at Forbrukerombudet det sidste år har sat fokus på reklame for slankemidler, som egentlig hører under Mattilsynets ansvarsområde. 
Det er vanskeligt at sige noget konkret om forholdet mellem tilsynet med markedsføringsloven som generel lov og tilsynet med lovgivningen på specialområderne. Generelt gælder dog, at Forbrukerombudets tilsyn sker på baggrund af overordnede forbruger- og samfundshensyn, men nok med en vis tilbageholdenhed på specialområder, hvor der findes særlig tilsynsmyndighed, mens de andre tilsyn i noget højere grad lægger vægt på særlige hensyn som sundhed, sikkerhed, miljø m.m. På denne måde er der også i Norge en vis risiko for, at tilsynet med vildledningsproblemerne på specialområderne kommer til at blive lidt stedmoderligt behandlet hos begge sæt myndigheder.

Bødeniveauet i Norge vedrørende overtrædelse af markedsføringsloven ligger mellem 100.000 og 500.000 NOK. I flere tilfælde er der givet bøder på omkring 300.000 NOK til det firma, der har krænket vildledningsforbudet plus bøder på 100.000-150.000 NOK til den eller de ansvarshavende personer i firmaet. 


\section{Finland}

\subsection{Generel regulering af vildledning}

\subsubsection{Konsumentskyddslagen og Konsumentombudsmanden}

Konsumentskyddslagen er et stort, samlet lovkompleks, der regulerer den finske forbrugerbeskyttelse både i relation til markedsføringsretlige og privatretlige spørgsmål.

Formålet med markedsføringsbestemmelserne i loven er at forhindre utilbørlig påvirkning af forbrugernes beslutninger samt at sikre, at de oplysninger, som forbrugerne får i forbindelse med markedsføringen, er tilstrækkelige og korrekte. Reglerne er formuleret som brede generalklausuler, hvilket gør bestemmelserne om markedsføring fleksible, således at forbrugernes interesser tilgodeses, også når markedsføringsmetoderne og de forbrugerpolitiske vurderinger forandres.

Konsumentskyddslagen gælder efter 1 . kap $1 \S$ udbud, salg og anden markedsføring af varer og tjenesteydelser fra erhvervsdrivende til forbrugere. Konsumentskyddslagen indeholder i kapitel 2 de regler, der modsvarer markedsføringsloven i Danmark, Norge, Island og Sverige.

Den finske markedsføringslovgivnings store generalklausul findes i 2. kap. $1 \S$, hvorefter der ved markedsføring ikke må udføres handlinger, som strider mod god skik, eller som på anden måde er utilbørlige over for forbrugerne.

Efter 2. kap $1 \S$ stk. 2 skal markedsføring, som ikke indeholder de oplysninger, som er påkrævet af hensyn til forbrugernes sundhed eller økonomiske tryghed, altid anses for utilbørlig.

Den finske markedsføringsrets generelle forbud mod vildledning findes i Konsumentskyddslagens 2. kap. 2 §. Reglen lyder: »Ved marknadsföring får ej lämnas osanna eller vilseledande uppgifter «.

Formålet med denne regel er at betone, at det er særligt forkasteligt at give usande og vildledende oplysninger ved markedsføring. De vildledende oplysninger, som strider mod denne regel, er ofte af et sådant indhold, at forbrugerne på den ene eller den anden måde gives en fejlagtig opfattelse af et tilbuds indhold/værdi, et produkt eller omstændigheder, som vedrører anskaffelsen heraf.

Begrebet vildledning gives også i Finland en bred fortolkning, og også markedsføring, som bygger på i og for sig korrekte oplysninger, kan være at anse som vildledende, hvis væsentlige oplysninger, som har betydning for vurderingen af produktet i sin helhed, forties eller gives på uklar eller utydelig måde. Det forudsættes i Konsumentskyddslagen, at den, der 
markedsfører et produkt, på overbevisende måde kan føre bevis for de påstande, som fremføres som fakta i markedsføringen. Det vil sige, at såfremt markedsføreren anfører noget om produktet, som er konkret eller målbart om et produkts egenskaber eller virkninger, skal dette kunne dokumenteres, og oplysningerne må ikke fortegne billedet af produktets virkelige egenskaber.

Konsumentombudsmanden overvåger markedsføringens virkning og lovlighed ud fra en forbrugersynsvinkel. Konsumentombudsmanden har omfattende generelle beføjelser i relation til at regulere de erhvervsdrivendes markedsføring, men i første omgang skal han som udgangspunkt forhandle med de erhvervsdrivende. Der udfærdiges vejledende udtalelser og retningslinjer, som f.eks. sendes til de erhvervsdrivende, der har vist ved deres markedsføring, at de har behov for en orientering om, hvad der er reel markedsføring. Hvis ikke dette fører til en markedsføring, der er i overensstemmelse med lovgivningen og de for forholdet relevante retningslinjer, kan Konsumentombudsmanden nedlægge forbud og foreløbige forbud i overensstemmelse med Lov om Konsumentombudsmanden. Langt de fleste sager ender dog efter forhandlingerne med, at den erhvervsdrivende indretter sin markedsføring efter Forbrugerombudsmandens anvisninger.

Hvis der er tvist mellem Konsumentombudsmanden og den erhvervsdrivende om forståelse af Konsumentskyddslagens rette forståelse, kan sagen indbringes for Marknadsdomstolen, hvor også straffesager vedrørende markedsføringsretlige overtrædelser føres.

Handlinger, der strider mod Konsumentskyddslagens 2. kapitel eller mod regler udfærdiget med hjemmel heri, kan som ovenfor nævnt forbydes, jf. 2. kap 7 §. Et sådant forbud kan støttes af en bod for overtrædelse heraf, medmindre dette af særlig grund anses for unødvendigt. Denne bod udløses kun, såfremt den erhvervsdrivende ikke efterkommer forbudet. Forbud efter $\S 7$ nedlægges af Marknadsdomstolen, som også har mulighed for at nedlægge foreløbigt forbud, som gælder til sagen endeligt er prøvet ved Marknadsdomstolen.

Konsumentombudsmanden har udarbejdet en lang række vejledninger om markedsføring af konkrete produkter. Som eksempel kan nævnes retningslinjer om markedsføring af levnedsmidler i forhold til børn, hvori der fastlægges nogle retningslinjer for, hvilke salgsargumenter og metoder, der ikke kan anses for at være acceptable. Der må således ikke anvendes reklamer, hvor børn direkte opfordres til køb, hvor man lader børnene forstå, at indtagelse af en fødevare kan gøre én mere populær, mindre ensom, gladere, give én flere venner m.v. det må heller ikke anføres, at en slikkepind er sund, blot fordi den er fedtfattig eller at en slikkepind er sund, fordi der er »ægte frugt« i den. Det er korrekt, at der ikke er fedt i slikkepinde, men der er til gengæld en stor mængde sukker, og selv om der er frugt i en slikkepind, er dette i ubetydelige mængder. 
Dette er således eksempler på oplysninger, der i princippet er korrekte, men som alligevel er vildledende.

Konsumentombudsmanden har også udfærdiget retningslinjer vedrørende markedsføring af slankeprodukter. En påstand i markedsføringen, der angiver, at et produkt eller en behandlingsmetode har afmagringseffekt, er en sådan faktisk påstand, som markedsføreren skal kunne bevise. Sådanne udtryk som "gå ned i vægt uden diæt«, »bestem selv, hvor meget du vil gå ned i vægt«, »målbare resultater allerede efter den første behandling « m.v. er omfattet af dette dokumentationskrav, ligesom påstande om, at et produkt fremmer blodcirkulationen, får fedtcellerne til at "smelte bort« o. lign., skal kunne bevises ved en upartisk og videnskabeligt pålidelig dokumentation. Sager om slankeprodukter overvåges af Forbrugerombudsmanden.

Også miljøargumenter i markedsføringen overvåges af Forbrugerombudsmanden i overensstemmelse med de fællesnordiske retningslinjer for miljørelaterende argumenter i markedsføringen. Her gælder kravet om dokumentation af faktiske oplysninger også. Ordet »miljøvenlig « eller tilsvarende bredt formulerede udtryk (»grøn«, »økologisk«, "naturvenlig«) må kun anvendes, hvor det faktisk er blevet undersøgt nøje, at produktet modsvarer denne påstand i hele sin »livscyklus«. Markedsføringen bedømmes her - som i alle andre forhold - ud fra det totalindtryk, forbrugeren får af markedsføringen, og der må ikke henvises til miljøpåvirkninger om hvilke, der er delte meninger. Når miljøpåstandene bedømmes, sker dette sammenholdt med andre, tilsvarende produkter. Således er påstanden, at et produkt er »fosfatfrit « vildledende, hvis der ikke findes andre produkter på markedet, der indeholder fosfat.

Den, som ved erhvervsmæssig markedsføring af forbrugsgoder giver usande eller vildledende oplysninger, som er af væsentlig betydning for markedsføringens målgruppe, kan dømmes til bøder eller fængsel i op til et år for markedsføringsbrud. Anklagemyndigheden skal inden påtale rejses for markedsføringsbrud give Forbrugerombudsmanden mulighed for at udtale sig i sagen.

Vildledende markedsføring kan i særligt alvorlige tilfælde straffes i medfør af straffeloven.

\subsubsection{Praksis vedrørende overtrcedelse af Konsumentskyddslagens vildledningsregler}

Overtrædelse af forbudet mod vildledning er også i Finland en af de hyppigste markedsføringsforseelser. Konsumentskyddslagen anvendes over et bredt spektrum af markedsføringsretlige overtrædelser. Således er også sager om anvendelse af vildledende markedsføring vedrørende kosmetiske produkter, produkter, der påberåbes at have effekt som lægemidler og vildledende eller udokumenterbare miljøpåstande ført for Marknadsdomstolen i medfør af 2 kap. 2 § i Konsumentskyddslagen. 
Som eksempel på overtrædelse af reglerne om vildledning kan nævnes en tidligere sag fra Marknadsdomstolen fra 2001 vedrørende en tvreklame for et telefonabonnement, hvor prisoplysningerne om abonnementsprisen var givet med meget lille tekststørrelse sammenlignet med tilbudets pris (pr. talt minut), der fyldte hele skærmen. Marknadsdomstolen fastslog, at hvis reklame gøres for en specifik abonnementstype, skal de typiske samlede udgifter oplyses tydeligt i overensstemmelse med prismærkningslovgivningen. I den aktuelle sag var det så godt som umuligt at få overblik over de faktiske udgifter. Marknadsdomstolens afgørelse indebar et forbud mod denne reklame samt en fastsat bod for brud på dette forbud på 300.000 FIM (50.000 euro). Högsta Domstolen har senest i 2006 nedlagt forbud mod at fortsætte med en sådan markedsføring af mobiltelefonabonnement, hvor forbrugerne blev tilbudt gratis taletid, men hvor forbrugerne ikke kan udnytte tilbudet i sin helhed, og hvor den erhvervsdrivende ikke bandt sig til at fastholde størrelsen af tilbudet i den periode, det skulle kunne udnyttes. Der er dog ikke oplyst nogen bod tilknyttet denne afgørelse.

I MD 1997:8 dømte Marknadsdomstolen i en sag anlagt af Konsumentombudsmanden mod to erhvervsdrivende firmaer og en administrerende direktør. Firmaerne havde markedsført et produkt, som angiveligt kunne få håret til at gro på personer, der var blevet skaldet, samt standse hårtab hos andre. Firmaerne havde endvidere markedsført et afmagringsprodukt, som skulle kunne virke afmagrende, uden at personen behøvede at ændre sine kostvaner. Begge produkter fremstod med billeder af »før « og "efter « personer og med oplysninger og beretninger fra private personer og eksperter. Ingen af de påståede virkninger kunne dokumenteres. Endelig lovede firmaerne en "garanti«, som ikke stillede forbrugerne bedre end lovens præceptive regler. Markedsføringen ansås for vildledende, jf. 2. kap 2 § i Konsumentskyddslagen, og Marknadsdomstolen forbød firmaerne at fortsætte med markedsføringen. Forbudet blev befæstet med en bod på 300.000 FIM (50.000 Euro).

I sagen MD 1992:04 kunne to erhvervsdrivende ikke dokumentere, at ekstra isolering af finske parcelhuse utvivlsomt kunne have væsentlige positive miljøpåvirkninger, eller at husholdningernes varmeforbrug på grund af dårlig isolering og udslip af varme skulle bidrage væsentligt til drivhusfænomenet. Forbrugerne havde på baggrund af det udleverede reklamemateriale ikke mulighed for at vurdere de reelle miljøpåvirkninger af at pålægge deres huse yderligere isolering. Den erhvervsdrivendes markedsføring blev anset for vildledende og utilbørlig og i strid med 2 kar. 2 § i Konsumentskyddslagen. Marknadsdomstolen forbød firmaet at fortsætte med eller gentage denne markedsføring, og forbudet blev bestyrket med en bøde på 200.000 FIM (33.333 euro).

I MD 1990:17 førtes Konsumentombudsmanden sag mod et firma og dets administrerende direktør vedrørende et præparat, som skulle kunne hjælpe astmatikere, lindre hudsymptomer og forebygge kræft. For at disse 
virkninger lovligt kan fremføres i markedsføringen, kræves det, at medicinalstyrelsen har godkendt aftalen. Da markedsføringen var sket uden en sådan godkendelse, ansås markedsføringen for at have været utilbørlig.

Andre præparater markedsførtes som noget, der kunne mindske træthed, lindre sultfølelse og højne potens. Disse påstande kunne ikke siges at henvise til sygdomme, hvorfor medicinalstyrelsens godkendelse ikke var fornøden for denne type produkter/påstande. Medicinalstyrelsen udtalte dog, at forhandleren og producenten af produkterne ikke kunne dokumentere nogen videnskabeligt holdbare beviser for, at de nævnte virkninger fandtes. De erhvervsdrivende havde således ikke kunnet dokumentere, at markedsføringsargumenterne holdt stik. Henvisningen til, at præparaterne mindskede træthed var yderligere fremført på en måde, som kunne være farlig for trafiksikkerheden. Markedsføringen blev anset for at være vildledende og i strid med god markedsføringsskik for så vidt angik bemærkningerne om træthed i relation til trafikken.

Et præparat var markedsført som egnet til at modvirke alkohols akutte og langsigtede skadelige virkninger, hvilket ikke kunne dokumenteres, hvorfor markedsføringen ansås for at være vildledende, jf. Konsumentskyddslagens 2 kap. 1 og 2 §. Marknadsdomstolen forbød firmaet at fortsætte eller gentage markedsføringen, og forbudet blev bestyrket med en bøde på 100.000 FIM (16.666 euro)

I KO 2003/40/3721 førtes sag om markedsføringen af slikkepinden Chupa Chups. En reklame viste en pige i tiårsalderen, der fortalte, at hun foretrak Chupa Chups slikkepinde, fordi de indeholder $0 \%$ fedt. Et stærkt tema i hele reklamekampagnen var, at produktet var fedtfrit. Tilsvarende slikkepinde af andre fabrikater indeholder heller ikke fedt, så betoningen af fedtindholdet var vildledende. Reklamen gav yderligere det indtryk, at der var tale om et sundt mellemmåltid, eftersom der ikke indgik fedt. Da slikkepinden kun indeholdt sukker og forskellige tilsætningsmidler, anså konsumentombudsmanden reklamen for vildledende og i strid med Konsumentskyddslagens 2. kap. 2 §. Samme erhvervsdrivende har igen i 2005 foretaget lignende markedsføring!

\subsubsection{Konklusion vedrørende bødeniveauet i henhold til Konsumentskyddslagen}

Konklusionen på bødeniveauet for overtrædelse af Konsumentskyddslagen er, at der pålægges den erhvervsdrivende, der er ansvarlig for markedsføringskrænkelsen bøder, som i de nyeste sager har andraget 300.000 FIM (50.000 euro) Det fremgår ikke af domsreferaterne, efter hvilke principper, disse bøder/viter er udregnet, men lov om vite 2 kap 8 § bestemmer, at vitesbeløbet skal bestemmes med henblik på hovedforpligtelsens art og omfanget af den forpligtedes betalingsevne og øvrige omstændigheder, som indvirker på sagen. I praksis fastsættes vitet på baggrund af den erhvervsdrivendes omsætning. 


\subsection{Fødevarer}

\subsubsection{Livsmedelslagen og Livsmedelsverket}

Livsmedelslagen (levnedsmiddelloven) regulerer fødevareområdet, og formålet med loven er at sikre levnedsmidlers kvalitet med henblik på sundheden samt at beskytte forbrugerne mod sundhedsrisiko forårsaget af levnedsmidler, som er uegnet til menneskeføde, og mod økonomiske tab forårsaget af levnedsmidler, der forhandles i strid med levnedsmiddelbestemmelser.

Overvågning af, at markedsføringen af levnedsmidler overholder lovens bestemmelser, foretages på tre niveauer: Af de kommunale tilsynsmyndigheder, lensstyrelserne og Livsmedelsverket. De kommunale myndigheder og lensstyrelsen kan give råd og vejledning vedrørende reklame og markedsføring. Livsmedelsverket kan i medfør af levnedsmiddelloven nedlægge forbud over for en erhvervsdrivende, som bestiller eller selv foretager markedsføring, dersom markedsføringen strider mod levnedsmiddelloven eller bestemmelser udstedt med hjemmel heri. Der kan eventuelt nedlægges forbud mod, at den erhvervsdrivende foretager markedsføring af samme eller lignende art i fremtiden, ligesom Livsmedelsverket kan bestemme, at den erhvervsdrivende skal offentliggøre en rettelse af markedsføringspåstandene, som retter sig mod forbrugerne og andre aftagere af produkterne.

Markedsføringsforbud og påbud om rettelse af forkerte oplysninger eller vildledende markedsføring kan forstærkes med pålæggelse af bøde ved overtrædelse af Livsmedelsverkets bestemmelser.

Livsmedelsverkets afgørelser kan ankes til den relevante forvaltningsdomstol. Beslutninger om bøde kan påklages selvstændigt.

Markedsføring af levnedsmidler er udover levnedsmiddellovens regulering underlagt Konsumentskyddslagen og dennes generalklausul om god skik og forbud mod utilbørlig markedsføring jf. Konsumentskyddslagens 2 kap. 1 §. Der findes ikke nogen tilsvarende generalklausul i levnedsmiddellovgivningen, hvorfor afgørelse af, hvad der er utilbørligt eller stridende mod god skik, varetages af Konsumentombudsmanden.

På indpakningen af levnedsmidler, i brochurer, reklamer og anden markedsføring vedrørende levnedsmidler skal der i medfør af levnedsmiddellovens $\S 6$ gives korrekte og tilstrækkelige oplysninger om levnedsmidlet. Det er forbudt at give vildledende oplysninger om levnedsmidler, ligesom det er forbudt at fremsætte sundhedsanprisninger i form af påstande vedrørende levnedsmidlers indvirken på helbredet. Påstande og oplysninger, der tillægger levnedsmidlet medicinske egenskaber eller henviser til sådanne påstande, er ligeledes forbudt, medmindre andet er bestemt.

Konsumentverket og Livsmedelsverket har som ovenfor nævnt udfærdiget en instruks til de erhvervsdrivende om markedsføring af levneds- 
midler til børn. Instruksen bygger primært på regler om, hvad der er utilbørlig markedsføring, og hvad der strider mod god skik, men der indgår også »spilleregler«, som vedrører vildledning.

De oplysninger, der er reguleret af vildledningsforbudet i Levnedsmiddellovens $\S 6$, er oplysninger, der gives i tekster på emballage, information, som gives i forbindelse med salg af produktet og reklame og anden markedsføring uanset form, som f.eks. avisannoncer, elektronisk reklame, direkte henvendelser og mundtligt fremført reklame.

Påstande om ernæringsmæssigt indhold (ernæringsanprisninger) vedrørende levnedsmidlet, hvor det siges, gøres gældende eller antydes, at levnedsmidlet har specifikke ernæringsmæssige egenskaber, er tilladt, såfremt de er korrekte og relevante. Dette gælder f.eks. indholdet af energi, protein, fedt, kulhydrater, kostfibre, vitaminer m.v. Sådanne påstande kan være: »Laktosefri«, »fedtfattig«, »indeholder meget jern«, »fiberrig«, »let«, »kolesterolfri« m.v.

Handels- og industriministeren har udfærdiget vejledning om levnedsmiddelanprisninger, som skal følges ved markedsføring heraf. Det anses efter disse retningslinjer som vildledende at fremhæve, at et produkt ikke indeholder noget, som heller ikke findes i tilsvarende produkter, jf. ovenfor nævnt sagen om de »fedtfri« slikkepinde. Det er ligeledes vildledende at anføre, at et produkt indeholder noget, som kun findes i ubetydelige mængder.

Ved bedømmelse af sundheds- og ernæringsudsagns lovlighed gælder det (som ved al anden markedsføring), at man må vurdere det totalindtryk, som markedsføringen giver. Som eksempel kan nævnes, at bredt beskrivende ord som »funktionellt«, »hälsopåverkande livsmedel«, »hälsosamt « eller »bra for hjertet« er vildledende, såfremt det ikke samtidig angives, på hvilket grundlag dette er udtalt.

I bedømmelsen af påstandene om helbredsvirkninger skal der gås ud fra almindelige principper om, hvad der er normal kost, hvad der skal til, for at de sundhedsfremmende virkninger kan opnås og de fremførte beviser.

Bestemmelserne om vildledning skal også anvendes på oplysninger om forskellige undersøgelsesresultater, hvor der direkte eller indirekte henvises til produktets virkninger, som f.eks.: »Undersøgelser viser, at dette produkt muligvis kan ...«. Denne slags påstande viser, at der ikke findes beviser for påstanden, og hvor der fremføres konkrete, målbare anprisninger, skal disse kunne dokumenteres. Generelt holdte, upræcise vendinger såsom »forbedrer sundheden«, »fremmer den almene velbefindende«, "fremmer fedtforbrændingen« m.v. anses for at være vildledende.

\subsubsection{Praksis vedrørende fødevarelovgivningen}

Som eksempler på håndhævelse af vildledningsforbudet kan nævnes en sag vedrørende solbær-, tranebær-, blåbær- og ingefærpulver (Livsme- 
delsverket 23.12.2003). En erhvervsdrivende anførte i sin markedsføring, at solbærpulver skulle hjælpe mod højt kolesteroltal, højt blodtryk, hjerterytmeforstyrrelser, eksem og binyreinsufficiens og skulle give bedre hud.

Tranebærpulveret blev markedsført som forebyggende urinvejsinfektioner og oplystes at være vanddrivende. Blåbærpulveret blev markedsført som middel mod degeneration af nethinden, som skulle give bedre nattesyn og bedre hukommelse. Ingefærpulveret blev angivet som middel til afhjælpning af besvær i led og bevægeapparatet og mod degenerationsforandringer i leddenes brusk. Markedsføring med henvisning til forebyggelse, behandling eller helbredelse af sygdomme er altid forbudt, når det gælder levnedsmidler, uanset om der findes bevis for påstandene eller ej. I det aktuelle markedsføringsmateriale blev det direkte sagt, at ovennævnte produkter har positive virkninger på f.eks. risikofaktorerne ved hjerte- og karsygdomme, på mavefunktionen og på hukommelsen. Der var intet i de oplysninger, der forelå for Livsmedelsverket, der kunne dokumentere, at de markedsførte produkter var blevet undersøgt for disse virkninger. Det var heller ikke på anden måde bevist, at de omhandlede produkter skulle have positive virkninger for dem, der anvendte produkterne. Markedsføringen blev anset som vildledende i medfør af Levnedsmiddellovens $\S 6$, og Livsmedelsverket forbød den erhvervsdrivende at fortsætte med denne markedsføring. Forbudet blev befæstet med en bod på 10.000 Euro (ca. 75.000 FIM).

En anden sag vedrørte markedsføringen af råmælkskapsler (Livsmedelsverket 16.9.2003). I markedsføringsmaterialet hed det, at produktet indeholdt antistoffer og vækstfremmende emner, og reklamematerialet beskrev råmælkens virkning for immunsystemet og som middel der forhindrer bakterie- og virusvækst. Produktet blev markedsført som en »naturlig, funktionel næring, som forbedrer modstandskraft og præstationsevne, som energitilskud for sportsudøvere, motionister og rekonvalescenter samt som hjælp for dem, der skal komme sig efter overanstrengelse«. Endvidere blev der anført, at produktet var det stærkeste på markedet - dobbelt så stærk som tilsvarende produkter. Markedsføringen ansås som stridende mod Levnedsmiddellovens $\S 6$ på grund af henvisningerne til, at produktet havde egenskaber, der forebygger sygdom. Livsmedelsverket anså reklamens påstande for udokumenterede, da der ikke var foretaget tilstrækkelige videnskabelige undersøgelser som bevis for, at netop dette produkt har de egenskaber, der påberåbes i markedsføringen. Af disse grunde blev markedsføringen anset for vildledende, og Livsmedelsverket forbød firmaet at fortsætte denne markedsføring. Forbudet blev befæstet med en bod på 50.000 Euro (300.000 FIM). 


\subsubsection{Konklusion vedrørende bødeniveauet for vildledning på fødevareområdet}

Markedsføringen af levnedsmidler er i Finland reguleret både af Levnedsmiddelloven og dermed denne lovs vildledningsforbud i § 6 og af Konsumentskyddslagen og generalklausulen i dennes 2 kap. 1 §. Tilsynsmyndigheder er dermed både Livsmedelsverket og Konsumentombudsmanden

I situationer, hvor der er spørgsmål om markedsføring, og hvor begge myndigheder har beføjelser til at gribe ind, aftales det i det konkrete tilfælde mellem disse myndigheder, hvem der skal tage sig af sagen, og der samarbejdes om løsningen af problemet. Eksempelvis kan nævnes spørgsmål vedrørende markedsføring af slankemidler, hvor begge myndigheder har kompetence til at gribe ind. Her har konsumentombudsmanden ekspertise og erfaring vedrørende markedsføring og vildledning generelt, men ikke den ekspertise, som er nødvendig til bedømmelse af de beviser, der fremlægges til støtte for forskellige sundhedsrelaterede påstande. Livsmedelsverket har adgang til et netværk af specialister, som har mulighed for at vurdere disse beviser, men har ikke markedsføring som et af sine højst prioriterede fokusområder.

De bøder, der pålægges erhvervsdrivende for overtrædelse af Levnedsmiddellovens regler adskiller sig tilsyneladende ikke fra det niveau, der lægges til grund ved udmåling af bøder i medfør af Konsumentskyddslagen. Der er således i nyere sager pålagt bøder på 50.000 euro (300.000 FIM), som er parallelt med de seneste bøder på Konsumentskyddslagens område.

\subsection{Alternative behandlinger, naturmedicin, slankemidler, alkohol og tobak}

\subsubsection{Regler og tilsynsmyndigheder}

Medicinalstyrelsen er godkendende myndighed ved produkter, der ligner lægemidler (naturmedicin/alternativ medicin), medens Livsmedelsverket er tilsynsførende myndighed ved produkter, der må betegnes som kosttilskud.

Markedsføring af produkter, der ligner lægemidler, kræver altid tilladelse fra Medicinalstyrelsen, hvis produkterne tilskrives egenskaber, som helbreder, lindrer eller forebygger sygdomme eller sygdomssymptomer. Hvis der i markedsføringen blot henvises til almindelig sundhed, eller at produktet er sundhedsfremmende, kræves der ikke tilladelse fra medicinalstyrelsen.

Markedsføring af alternativ medicin og naturlægemidler skal godkendes, medens slankepræparater ikke vedrører en tilstand, der er omfattet af begrebet sygdom, hvorfor sådanne midler ikke er omfattet af godkendel- 
seskravet. Markedsføring af slankemidler finder sted under tilsyn fra Konsumentombudsmanden

Konsumentombudsmanden fører tilsyn med markedsføring af slankeprodukter og har udfærdiget en anvisning om markedsføring af sådanne. Ifølge denne vejledning skal eventuelle påstande om slankemidlets virkninger kunne dokumenteres ved videnskabelige og upartiske beviser. Dette beviskrav satte rammerne for, hvad den erhvervsdrivende kan love/antyde vedrørende slankemidlet.

Vildledende markedsføring efter Konsumentskyddslagen er udover ikke dokumenterbare påstande også udeladelse af væsentlige oplysninger. For slankemidlers vedkommende kan dette f.eks. være, at det undlades at gøres opmærksom på, at man for at opnå et vægttab også nødvendigvis må udøve mere motion eller ændre sine kostvaner.

Tobaksreklamer er i medfør af tobaksdirektivet forbudt i Finland, således som det er tilfældet i Danmark, Norge og Sverige. Der ses derfor heller ikke i Finland sager vedrørende vildledende reklamer for tobaksvarer, men alene vedrørende hvorvidt der er tale om en overtrædelse af forbudet mod reklamering.

\subsubsection{Praksis vedrørende overtrcedelse af vildledningsforbudet}

I Marknadsdomstolens sag MD 1990:17 var et præparat markedsført som et produkt, der kunne være til hjælp for astmatikere, lindre hudsymptomer og forebygge cancer. For at disse virkninger lovligt skulle kunne nævnes i markedsføringen, skulle denne have været godkendt i medicinalstyrelsen. Dette var ikke sket, hvorfor den erhvervsdrivende ved sin markedsføring blev anset for at have handlet utilbørligt. Et andet præparat skulle angiveligt kunne lindre gigtpatienters morgenstivhed og smerter. Denne markedsføring havde ligeledes været godkendelsespligtig, og den erhvervsdrivende blev anset for at have handlet utilbørligt.

Et præparat var markedsført som noget, der kunne lindre træthed, sultfølelse og fremme potensen. Da disse tilstande ikke er sygdomme, var medicinalstyrelsens godkendelse ikke nødvendig, men da påstandene om produkternes virkning ikke kunne dokumenteres, blev markedsføringen anset for vildledende og dele af den som værende i strid med god skik. Også markedsføring af et præparat, der skulle kunne modvirke alkohols skadelige virkninger, ansås som vildledende i medfør af 2. kap 2 § i Konsumentskyddslagen.

I markedsføringen af et præparat indgik et interview med en privatperson, hvor præparatets virkninger mod en sygdom blev beskrevet. En sådan markedsføring er omfattet af godkendelseskravet, hvilket ikke var opfyldt, og markedsføringen blev dømt utilbørlig over for forbrugerne. Marknadsdomstolen forbød den erhvervsdrivende at fortsætte eller gentage denne markedsføring, og dette forbud blev befæstet med en bod på 16.666 Euro. 
6.3.3 Konklusion vedrørende bødeniveauet for vildledning vedrørende alternative behandlinger, naturmedicin m.v.

Da alle disse produkter hører under tilsyn af Konsumentombudsmanden, må bødeniveauet ved vildledende markedsføring af sådanne produkter forventes at ligge på samme niveau som bøder pålagt for vildledningsforseelser vedrørende andre produkter. Der må derfor kunne forventes bøder på omkring 50.000 euro (300.000 FIM)

\subsection{Miljøargumenter, kosmetik m.v.}

\subsection{1-2 Regler, tilsynsmyndighed, praksis.}

Den finske Konsumentombudsmand har deltaget i udarbejdelsen af de nordiske forbrugerombudsmænds vejledning vedrørende etiske og miljørelaterede udsagn i markedsføringen. Disse retningslinjer følges derfor også i Konsumentombudsmandens praksis. Miljøargumenter i markedsføringen overvåges også i Finland af konsumentombudsmanden. Se praksis under afsnit 6.1.2

Markedsføringen af kosmetiske midler er underlagt Konsumentskyddslagen og Konsumentombudsmandens tilsyn. Se ovenfor under afsnit 6.1.2

6.4.3 Konklusion vedrørende bødeniveauet for vildledende markedsføring af miljøargumenter og kosmetik

Da også disse produkter hører under Konsumentombudsmandens tilsyn, må bødeniveauet ved vildledende markedsføring af sådanne produkter forventes at ligge på samme niveau som bøder pålagt for vildledningsforseelser vedrørende andre produkter. Der må således forventes at kunne blive pålagt bøder i størrelsesordenen op til 50.000 euro (300.000 FIM)

\subsection{Konklusion vedrørende Finland}

Konsumentskyddslagen regulerer al markedsføring i medfør af dens generalklausul i lovens 2 kap. $1 \S$, og denne regel er den primære vedrørende overholdelse af god markedsføringsskik Selv om Konsumentombudsmanden dermed har generelle beføjelser, er det dog som hovedregel specialmyndighederne, der overvåger hvis der findes særlig lovgivning.

En meget stor del af markedsføringen er i Finland lagt under Konsumentombudsmandens tilsyn og er reguleret af Konsumentskyddslagens 2 kap. 1 §. Hvor dette ikke er tilfældet, som f.eks. vedrørende tilsynet med markedsføring af levnedsmidler, finder der et samarbejde sted mellem de relevante myndigheder (Konsumentverket og Livsmedelsverket), således 
at begge myndigheders erfaring og ekspertise bliver udnyttet, og det aftales i det enkelte tilfælde, hvilken af myndighederne, der skal tage sig af sagen. Der er derfor tilsyneladende en god konsistens i tilsynet med markedsføringen, og bødeniveauet udviser ingen forskelle uanset hvilket produkt, der er solgt ved anvendelse af vildledende markedsføring.

Bødeniveauet ligger således, at er i de nyeste sager er pålagt den, der er ansvarlig for markedsføringen bøder på op til 50.000 euro (300.000 FIM). 


\section{Sverige}

\subsection{Generel regulering af vildledning}

\subsubsection{Markedsføringsloven og Konsumentombudsmanden}

Svensk markedsføringsret indeholder som de andre nordiske lande en generalklausul, der fastlægger hovedprincipperne for, hvorledes markedsføring skal foretages for at være i overensstemmelse med acceptabel markedsadfærd. Denne generalklausul findes i markedsføringslovens $§ 4$.

Markedsføringslovens $\S 4$ kræver, at markedsføringen skal stemme overens med god markedsføringsskik og tillige i øvrigt være tilbørlig over for forbrugere og erhvervsdrivende.

Hovedprincippet efter denne generalklausul er, at al markedsføring uanset form og medie skal være vederhæftig. Dette indebærer bl.a. et krav om sandhed og dokumenterbarhed for konkrete oplysninger, der gives i forbindelse med markedsføring. Der må heller ikke i Sverige gives korrekte oplysninger, der er egnet til at vildlede forbrugere eller erhvervsdrivende, ligesom udeladelse af væsentlige oplysninger er i strid med generalklausulen.

Generalklausulen om god markedsføringsskik suppleres af mere præciserede regler om vildledning i lovens $\S \S 5$-13a. Disse regler udgør tilsammen den generelle regulering af forbudet mod vildledning i svensk ret, og de er i det store og hele identiske med vildledningsreglerne i de øvrige nordiske lande i deres materielle indhold..

Reglernes overholdelse er i medfør af $\S 14$ sanktioneret dels ved nedlæggelse af forbud, som kan pålægges både den erhvervsdrivende og medansvarlige ansatte, nogen der handler på den erhvervsdrivendes vegne, og den som i øvrigt væsentligt har bidraget til markedsføringen, jf. markedsføringslovens $\S 14$. Der kan endvidere nedlægges påbud over for samme personkreds, jf. §§ 15 og 16.

Samtidig med, at der nedlægges forbud og påbud, fastsættes en vite (bod) som skal betales ved en eventuel senere overtrædelse af dette forbud eller påbud, jf. § 19. Denne bod kan dog undlades, hvor dette af særlige grunde er unødvendigt. Bodens størrelse skal fastsættes til et beløb, der tager udgangspunkt i, hvad der er kendt om adressatens økonomiske forhold og som omstændighederne i øvrigt taget i betragtning kan forventes at kunne formå ham til at følge det pålæg, som er anledningen til boden. Boden kan pålægges som løbende bod, ligesom det kan bestemmes, at boden skal betales hver gang, forbudet bliver overtrådt. Den endelige pådømmelse af boden sker efter indberetning fra den myn- 
dighed, der har pålagt den erhvervsdrivende forbudet. Sagen føres herefter ved Tingsretten. Vite er reguleret af lag 1985:206 om viten.

Herudover kan en erhvervsdrivende eller nogen, der handler på dennes vegne, i medfør af markedsføringslovens $\S 22$ pålægges at betale en særlig afgift for markedsforstyrrelse ved forsætlig eller uagtsom overtrædelse af markedsføringslovens $\S \S 5-13$ og 13 c, eller for at overtræde bestemmelserne i et givet forbud. Markedsforstyrrelsesafgift må ikke pålægges for overtrædelsen af et forbud eller en undladelse af at følge et påbud, som er meddelt sammen med vite: Således kan en erhvervsdrivende ikke komme til at betale både vite og markedsforstyrrelsesafgift for samme forseelse, jf. markedsføringslovens § 23.

Markedsforstyrrelsesafgift fastlægges til mindst 5.000 SEK og højst 5 millioner SEK og max. 10 \% af den erhvervsdrivendes årsomsætning, jf. $\S 24$.

Konsumentombudsmanden og Konsumentverket er en og samme myndighed og har tilsyn med markedsføringen generelt vedrørende samtlige de områder, som denne rapport omfatter.

Konsumentverket søger ved forhandling og udstedelse af retningslinjer at få de erhvervsdrivende til at overholde reglerne i markedsføringsloven. Såfremt dette ikke kan lade sig gøre, enten fordi den erhvervsdrivende ikke ønsker at ændre sin markedsføring, eller fordi han mener, at den er i overensstemmelse med god markedsføringsskik og ikke vildledende eller på anden måde i strid med lovens regler, kan Konsumentombudsmanden anlægge sag ved Marknadsdomstolen, som er den relevante domstol i sager af markedsføringsmæssigt indhold..

Konsumentombudsmanden kan efter markedsføringslovens $\S 21$ i sager, som ikke er af større eller principiel vægt, meddele administrative forbud og påbud, som skal kombineres med vite. Hvis den erhvervsdrivende kan godkende Konsumentombudsmandens forlæg, gælder dette med samme retskraft som en dom. Størrelsen af vitet er i denne mere ukomplicerede type sager ofte omkring 200.000 SEK Hvis den erhvervsdrivende ikke kan vedtage Konsumentombudsmandens forlæg, indbringer denne sagen for Marknadsdomstolen,

\subsubsection{Praksis vedrørende overtrcedelse af markedsføringslovens vildledningsregler}

Overtrædelse af markedsføringslovens regler om vildledning udgør uden sammenligning den mest almindelige form for utilbørlig fremgangsmåde. Vildledningsforbudet gælder overalt i markedsføringen og således også på de specialområder, der i øvrigt er reguleret af speciallovgivning.

I det følgende anføres en række sager, der alle er afgjort efter markedsføringslovens regler om vildledning, god markedsføringsskik og utilbørlig adfærd over for forbrugere og erhvervsdrivende. En del af dem er afgjort direkte efter reglerne om vildledning i markedsføringslovens $\S$ 
6, medens en stor del er begrundet $i$, at en markedsføring er uvederhæftig og dermed kan virke vildledende, hvorfor den er utilbørlig og i strid med god markedsføringsskik. I praksis anvendes derfor ofte markedsføringslovens $\S 4$ og en eller flere af de mere præciserede regler i §§ 6-13a sammen, og mange domme citerer to regler. De nævnte bødesager er alle kombineret med afgørelser om forbud mod en konkret markedsføringsadfærd.

Markedsdomstolen har i en række af de nyeste afgørelser vedrørende vildledende markedsføring fastlagt vitesbeløbet på 400.000 SEK Dette gælder i sagerne MD 2003:26 om medvirken til vildledende reklame i kuponhæfter, MD 2005:36 om »Sveriges laveste priser« og "Sveriges bedste priser«, MD 2004:28 »Ingen er billigere«, MD 2004:27 vedrørende brugen bl.a. af ordene »største byggevarehuskæde«, »bedste priser«, »størst og bedst« m.m.

I nogle tilfælde øges vitesbeløbet til 500.000 SEK, hvilket skete i MD 1993:28 vedrørende en reklame, der var forvekslelig med et tidsskrift. MD motiverede det højere vitesbeløb med, at reklamen henvendte sig til en i almindelighed svagere og mere modtagelig gruppe af forbrugere.

MD 2006:5 fastsatte Marknadsdomstolen vitesbeløbet til 500.000 SEK i en sag, hvor en erhvervsdrivende anvendte formuleringen »Vi har de bästa priserna«, uden at kunne bevise dette.

Der ses dog også afgørelser, der ligger på et lavere bødeniveau. Se således MD 1999:26 om direkte reklame til børn samt vildledning vedrørende vitamintilskud (bøde 300.000 SEK), For vildledende markedsføring af sammenhængen mellem priser og forsikringssummer MD 2000:22 om en golfklubs utilbørligt og vildledende markedsføring, MD 2000:31 om »laveste pris« (begge med en bøde på 200.000 SEK). I de tilfælde, hvor Konsumentombudsmanden har meddelt et forbud eller pålæg efter markedsføringslovens § 21 i sager, som ikke er af større eller principiel vægt, bestemmes normalt vitesbeløbet til 200.000 SEK og i enkelte tilfælde til 100.000 SEK

Markedsføringsloven anvendes på vildledende markedsføring, uanset hvilket produkt, der reklameres for. Således findes også sager om vildledende og utilbørlig markedsføring af fødevarer, kosttilskud, slankemidler, helseprodukter og »alternative behandlingsmidler«, kosmetik, miljøudsagn, alkohol og tobak.

Også vildledende markedsføring af fødevarer, kosttilskud, slankemidler og helsekost pålægges i nyere afgørelser vite i størrelsesordenen op til 400.000-500.000 SEK Se således MD 2004:8, der vedrørte vildledende markedsføring vedrørende kyllingers leveforhold og dermed følgende nedsatte salmonellarisiko, MD 2002:20 vedrørende yoghurt med »champagnesmag«, MD 2005:18 »Verdens bedste svinekød« samt MD 2003:26 vedrørende et slankeprodukt, hvor der i alle sager blev udmålt vite på 400.000 SEK 
I MD 2003:26 og MD 2004:20 blev der i begge sager pålagt vite på 400.000 SEK for vildledende og utilbørlig markedsføring af slankeprodukter.

I MD 2002:18 pålagdes en vite på 500.000 SEK for fødevarer, der blev oplyst at være "garanteret usprøjtet« samtidig med, at markedsføringen var aggressiv og utilbørlig i sammenligningen af disse varer med andre.

I ældre sager ses niveau for de pålagte viter på 100.000-200.000 SEK Dette findes i MD 1984:12 om biomagnetiske armbånd (100.000 SEK), MD 1991:15 om et helsekostprodukt/slankemiddel og en hudcreme (2 x 100.000 SEK/1 x 200.000 SEK), MD 1992:18 vedrørende mineralsalt (200.000 SEK), MD 1988:26 vedrørende en »slankethe« (100.000 SEK) og MD 1983:14 om et diætprodukt Dietoform (100.000 SEK).

Endelig blev der i MD 2003:6 pålagt den erhvervsdrivende en vite på 250.000 SEK for vildledende markedsføring af cider som frugtvin (250.000 SEK i bøde).

Erhvervsdrivende, der anfører miljøargumenter i markedsføringen, der er uvederhæftige og vildledende, pålægges vite på et tilsvarende niveau. Se således MD 2004:4, hvor en bil markedsførtes som rensende luften for skadeligt ozon, »renser luften« m.m. (400.000 SEK), MD 2002:18 om garanteret usprøjtede levnedsmidler (500.000 SEK - også nævnt ovenfor under praksis vedrørende fødevarer), MD 2004:12 vedrørende miljøargumenter ved markedsføring af en bil (400.000 SEK), MD 2004:15 vedrørende rengørings-/pudsemidler (400.000 SEK) og MD 2005:11 om sammenligning mellem økologisk og konventionelt dyrkede produkter (400.000 SEK).

Praksis vedrørende naturmedicin udviser samme tendens med vite stigende fra omkring 100.000 SEK (MD 1983:14, MD 1982:3, MD 1987:10, MD 1988:9) over 200.000 SEK (MD 1988:28, MD 1988:29, MD 1991:15, MD 1993:1, MD 1994:28) til 400.000 SEK (MD 2005:9, MD 2005:24) og 500.000 SEK ved særligt grove tilfælde.

I ældre sager ligger viteniveauet på 100.000-200.000 SEK Dette var tilfældet i MD 1989:2 (plastbæreposer/papirposer), 1990:20 (fyringsolie), MD 1990:22 (opvaskemiddel), MD 1991:11 (»miljøvenlig« bil), der alle tildeltes en vite på 100.000 SEK og MD 2000:31 (farveprodukter), hvor vitet var på 200.000 SEK

Markedsføringsloven anvendes ligeledes på markedsføring af kosmetiske produkter, hvor der i sagen MD 2000:4 blev pålagt en vite på 200.000 SEK for utilbørlig markedsføring af en hudcreme.

Reklamering med tobaksvarer er forbudt i Sverige i medfør af Tobaksdirektivet, og reklamer for alkohol er forbudt for alkoholiske drikke med en alkoholprocent over 2,8. (dette forbud lempes nu, hvorefter de bliver lovligt at reklamere for drikke med under $15 \%$ alkohol). Markedsføring af alkohol og tobak er også reguleret af markedsføringsloven. Det er dog ikke afgørelser vedrørende vildledning, der dominerer dette områ- 
de, men alene salg af tobak og alkohol i strid med speciallovgivningen herom. Sådan markedsføring anses for at være utilbørlig og i strid med god markedsføringsskik, og viteniveauet følger tilsyneladende praksis på andre områder.

\subsubsection{Konklusion vedrørende viteniveauet i henhold til markedsføringsloven}

Der føres i Sverige ganske mange sager vedrørende overtrædelse af forbudet mod vildledende markedsføring, og markedsføringsloven anvendes vedrørende vildledende markedsføring af alle typer af produkter.

Konklusionen på viteniveauet vedrørende vildledende markedsføring $\mathrm{i}$ medfør af markedsføringslovens er, at der af Markedsdomstolen tilsyneladende findes en forholdsvis fast praksis for viternes størrelse. Niveauet for viterne har udviklet sig fra at ligge omkring 100.000 SEK i 1980'erne til i dag at ligge omkring 400.000 SEK med enkelte viter på 500.000 SEK i særlige tilfælde. Viterne gives lige store, uanset hvilket produkt, den vildledende markedsføring vedrører..

\subsection{Fødevarer}

\subsubsection{Livsmedelslagen, Livsmedelsverket og Konsumentverket}

Fødevareområdet reguleres af Livsmedelslagen (1971:511 med senere ændringer). Denne lov er udfærdiget således, at EU’s fødevareforordninger implementeres i svensk ret. Loven suppleres af Livsmedelsforordningen (1971:807) samt af en lang række særforskrifter vedrørende konkrete produkter, salgsformer, mærkning m.v., samt af vejledninger bl.a. for fødevarers mærkning og præsentation. Al reklame for levnedsmidler og især anden reklame end den, der findes på mærkning af levnedsmiddelemballage bedømmes efter markedsføringsloven.

Livsmedelsverket er tilsynsmyndighed vedrørende Livsmedelslagen med tilhørende bekendtgørelser og vejledninger, men alle former for markedsføring er reguleret af markedsføringsloven, og sanktioneringen heraf er henlagt til Konsumentverket og Konsumentombudsmanden. Overtrædelse af særlovgivningen anses som utilbørlig markedsføring, som er i strid med markedsføringslovens § 4, og eventuelt også som uvederhæftig og vildledende.

Livsmedelslagen indeholder ikke et egentligt vildledningsforbud, men i §§ 16-20 regler om mærkning af fødevarer. I § 19 bestemmes således, at levnedsmidler ikke må sælges under nogen betegnelse, der kan bevirke, at forveksling med andre levnedsmidler let kan ske. 
Livsmedelsforordningen fastlægger rammer for en række tekniske spørgsmål vedrørende fødevarers håndtering, opbevaring m.m., men ikke regler om markedsføring og dermed heller ikke om vildledning.

Livsmedelsverket har udstedt forskrift om mærkning og præsentation af levnedsmidler (LIVSFS 2004:27), der er beregnet til at sælges i Sverige eller lande, der er tilknyttet det europæiske økonomiske samarbejdsområde, samt Tyrkiet.

Mærkningsforskriftens $\S 5$ indeholder regler om redelighed. Mærkningen og dens udformning må ikke kunne vildlede køberen særligt med henblik på levnedsmidlets beskaffenhed, identitet, egenskaber, holdbarhed m.m. Mærkningen må endvidere ikke tilskrive levnedsmidlets virkninger eller egenskaber, som det ikke har, eller antyde, at levnedsmidlet har bestemte egenskaber, såfremt alle lignende levnedsmidler har tilsvarende egenskaber.

Efter $\S 5$, litra b, og $\S 6$ må mærkning, præsentation af varen og varens udformning eller udseende eller salgsform ikke tilskrive levnedsmidlets egenskaber, som angiver, at de forebygger, behandler eller helbreder nogen sygdom hos mennesker eller antyde sådanne egenskaber. Herfra er der nogle få konkrete undtagelser.

I Livsmedelsverkets vejledning om mærkning og præsentation af levnedsmidler (LIVSFS 2004:27) fastlægges nærmere regler for, hvorledes reglerne skal efterleves. Det hedder heri, at mærkningen ikke må vildlede forbrugerne, hvorefter brugen af en lang række betegnelser og udtryk nærmere beskrives. Bl.a. fastlægges det, at det ikke er nok, at en oplysning er sand. Den kan være vildledende, såfremt den inddrager uvedkommende forhold, er urimeligt mangelfuld eller fastslår som noget særligt en egenskab, der gælder også for tilsvarende levnedsmidler.

Reglerne i Livsmedelslagen med tilhørende bekendtgørelser og vejledninger indeholder hjemmel til, at tilsynsmyndighederne kan foretage sanktioner over for den, der producerer og forhandler levnedsmidler. Disse sanktioner består i forbud, påbud, bøde, vite og erstatning, men markedsføringen af levnedsmidler overvåges af Konsumentverket og Konsumentombudsmanden. På områder vedrørende ernæringsspørgsmål og andre emner, der berører levnedsmidlers sammensætning finder der et nært samarbejde sted mellem Konsumentverket og Livsmedelsverket.

\subsection{2-3 Praksis vedrørende fødevarelovgivningen og konklusion herpå}

Da alle overtrædelser af forbudet mod vildledende markedsføring er reguleret af markedsføringslovens regler og føres af Konsumentombudsmanden, er praksis at finde under afsnit 7.1.1 og 7.1.2

Der er kun offentliggjort meget få sager ført af levnedsmiddelmyndighederne vedrørende utilbørlig, uvederhæftig og vildledende markedsføring alene efter levnedsmiddellovgivningen. Der kan derfor ikke udledes noget om praksis vedrørende viteniveau for vildledende markedsføring, 
som alene er baseret på regler i levnedsmiddellovgivningen, uanset at der er hjemmel i Livsmedelslagens § 25 til at pålægge de erhvervsdrivende forbud og påbud med sanktionering i form af vite for overtrædelse af disse regler. Der er således kun fundet en enkelt sag (RÅ 1992 ref 95), hvor Regeringsrätten stadfæstede Statens Livsmedelsverks forbudsforelæg bl.a. begrundet i en overtrædelse af Livsmedelslagens § 19. Den store hovedpart af sager føres som nævnt i medfør af markedsføringsloven, hvorfor der ikke er noget specielt at bemærke vedrørende bødeniveauet

\subsection{Alternative behandlinger, naturmedicin, slankemidler, alkohol og tobak}

\subsubsection{Regler og tilsynsmyndigheder}

Markedsføring af tobaksvarer er reguleret af Tobaksloven (1993:581), der i § 14 indeholder et forbud mod reklamer i periodiske skrifter, radioog TV-programmer . Et markedsføringstiltag, der strider mod tobakslovens $\S \S 14,14$ a, og 14 b, skal i medfør af markedsføringslovens $\S \S 4$, anses som utilbørlig mod forbrugerne.

Markedsføring af et alkoholindhold under $15 \%$ er underlagt færre restriktioner og begrænsninger end markedsføring af tobak, og reklamer for øl og vin er tilladt i ugeblade og aviser, men ikke i radio og TV, jf. 4 kap. §§ 8-13 i alkoholloven. Alkoholloven (1994:1738) indeholder i § $11 \mathrm{a}$, stk. 3, et forbud mod vildledende oplysninger om alkohol, alkoholforbrug, alkoholens virkninger eller andre egenskaber.

Overtrædelse af reglerne om markedsføring af alkohol i alkohollovens $\S \S 8-11$ b og § 11 c, stk. 1, skal i medfør af markedsføringslovens §§ 4, anses som utilbørlig,. Alkohollovens kapitel 8 indeholder reglerne om tilsyn med efterlevelse af loven.

Kap $8 \S 1$ a bestemmer, at tilsyn med efterlevelse af kap 4 §§ 8-11 og 13 reguleres efter reglerne i markedsføringsloven. Kommunerne fører tilsyn med overholdelse af reglerne om markedsføring af alkohol på serveringsstederne. Kommunernes tilsyn gælder ikke henvisningen til markedsføringslovens regler.

Der findes en række regler og retningslinjer for markedsføring af kosttilskud, slankemidler, naturmedicin og alternative lagemidler. Disse regler fastlægger bl.a. krav om bevis og dokumentation for påstande om produkters virkning og egenskaber. Som eksempel kan nævnes Retningslinjer for markedsføring af naturlægemiddel, som har fået midlertidig salgstilladelse (KOVFS 1993:4). 


\subsection{2-3 Praksis vedrørende overtrcedelse af vildledningsforbudet og konklusion herpå}

Tilsyn med al markedsføring for disse produkter er underlagt Konsumentverket og Konsumentombudsmanden, og markedsføringen bedømmes efter reglerne i markedsføringsloven. Det har derfor ikke været muligt at finde sager, hvor de erhvervsdrivende er dømt for vildledende markedsføring alene efter særlovgivningens regler.

\subsection{Miljøargumenter, kemiske produkter, kosmetik}

\subsubsection{Regler og tilsynsmyndighed}

Konsumentombudsmanden og Konsumentverket varetager tilsynet med overholdelse af regler og retningslinjer vedrørende miljømærkning og miljøargumenter i markedsføringen. Principperne i de nordiske forbrugerombudsmænds fælles regelsæt følges.

Sager vedrørende overtrædelse af reglerne om miljøargumenter i markedsføringen føres efter markedsføringslovens regler, og markedsføring i strid med disse retningslinjer eller regler i særlovgivningen anses som utilbørlige i medfør af markedsføringslovens $\S 4$ og eventuelt som uvederhæftige og vildledende. Det bemærkes hertil, at det efter markedsføringslovens $\S 6$, stk. 2, 2. punktum udtrykkeligt er forbudt erhvervsdrivende at anvende påstande eller anden form for fremstillinger vedrørende produktets indvirken på miljøet, som er egnet til at vildlede forbrugerne

Ovennævnte princip gælder uanset hvilket produkt, der sælges som "grønt«, »økologisk«, »skånsomt for miljøet«, »uskadeligt for miljøet« og lignende.

Der stilles høje krav til bevis og vederhæftighed på dette område, da sådanne anprisninger henviser til noget konkret, som kan bevises, og som virker som et stærkt konkurrenceparameter.

Også salg af kosmetiske produkter, rengøringsmidler og andre kemiske produkter er underlagt Konsumentombudsmandens overvågning og markedsføringslovens regler for god markedsføringsskik og forbud mod vildledning.

\subsection{2-3 Praksis vedrørende miljøargumenter m.v. og konklusion herpå}

Tilsyn med al markedsføring for disse produkter er underlagt Konsumentverket og Konsumentombudsmanden, og markedsføringen bedømmes efter reglerne i markedsføringsloven. Det har derfor ikke været muligt at finde sager, hvor de erhvervsdrivende er dømt for vildledende markedsføring alene efter særlovgivningens regler. 


\subsection{Konklusion vedrørende Sverige}

Konsumentverket og Konsumentombudsmanden har tilsyn generelt på samtlige områder, som denne rapport omfatter. Konsumentverket kan tage sager op på eget initiativ eller efter anmeldelse udefra, og anmeldelse om sager kommer primært fra privatpersoner/forbrugere. Konsumentverket foretager sig herefter det fornødne i sagen.

Dette giver en meget høj grad af konsistens i den svenske markedsføringsret og i sanktioneringen af forbudet mod vildledende markedsføring.

Bødernes (viternes) størrelse er i høj grad »standardiserende«, og der ses ikke forskel på hvilket produkt, der er markedsført på en retsstridig måde. Bødestørrelsen ligger i nyere praksis omkring 400.000 SEK med afvigelser i konkrete tilfælde. Vitets størrelse kan således påvirkes i opadgående retning af hvilken målgruppe, markedsføringen retter sig imod, hvor der i visse tilfælde er bemærket, at vitets størrelse skyldes, at målgruppen for markedsføringen ansås for at være en svagere og mere modtagelig gruppe. 



\section{Summary and conclusions}

\section{Summary}

The material contents of the Nordic countries' marketing acts and the regulation of the ban on misleading marketing are very much the same as regards the contents. There are of course small variations among the countries, but the standardising influence of EU law and the common Nordic background and legal tradition are very clearly seen.

The reason why there are still some differences as to how the ban on misleading marketing is sanctioned in the various countries is rather that the practical framework for the supervision of compliance has been approached differently:

In Denmark the ban on misleading marketing is vested in each of the special laws and supervision of compliance with these laws is spread among a large number of authorities which, seen from a lex specialis point of view, each have special competence within individual products and fields. The Consumer Ombudsman has the overall responsibility for supervising that traders comply with good marketing practice, but where a matter is covered by both special legislation and the marketing act, and where at the same time special supervision has been established in the field (competing supervision competencies), the Consumer Ombudsman will normally not take up cases. This means that the sanctioning of the ban on misleading marketing within special legislation sectors entirely depends on the control and practice of the special authorities.

As the special authorities in Denmark partly have a large number of diverse task of a more or less "technical" nature (e.g. concerning health and safety), partly have been subject to quite substantial cut-backs in resources in recent years, and finally are not particularly focussed on marketing, the supervision of misleading marketing is apparently given a lower priority with these authorities.

This causes some imbalances in the supervision of misleading marketing under the marketing act and under special legislation, which is reflected in the intensity of the supervision. In addition there has for historical reasons been considerable differences in the amounts of fines which is 400,000 DKK, and in several cases 1 or 2 million DKK, for violation of the marketing act, whereas fines for violation of special legislation are "standard fines" of about 10,000 DKK, with maximum fines of 50,000 DKK.

Iceland has changed its administrative surveillance system and laws regarding the supervision of marketing outside the fields of specila legislation. In July 2005 a new Act was adopted on supervision of unfair commercial practices and a new surveillance authority i.e. the Consumer 
Agency was established. The Consumer Agency is a new public authority which was formed by merging a Department of Consumer Protection issues previously supervised within the Competition Authority and the Office of Weigh's and Measures, both of which were abolished from the entry into force of the new Act This followed the realisation that the Iceland supervision and surveillance in these areas was not sufficiently effective and that there was a need for better and more flexible functioning of surveillance and control. The Consumer Agency has surveillance responsibilities and monitors trader's unfair commercial practices as well as i.a. safety of measurements, product safety and ensures market surveillance. At the same time the position of Consumer Spokesman was established who's tasks are i.a. to react when he deems the rights and interests of consumers have been violated and to tender Opinions along with suggestions for improvements under such circumstances to trade practioners as well as to public authorities. As these changes were only made one year ago, it is still too early to assess the effect the changes that have been made. It should be noted however that the level of fines, which has in practice been enacted in Iceland for violation of the provisions of the Act on Supervision of Unfair Commercial practices (up to 50,000 DKK), is assessed to be much too low to have sufficient preventive effect.

In Norway supervision of compliance with the ban on misleading marketing is, like in Denmark, shared by several authorities, and also here the marketing is somewhat neglected by the special authorities. This is however offset by the fact that the Consumer Ombudsman and the special authorities try to co-operate in the way that the Consumer Ombudsman for a period of time takes on supervision of the marketing of a particular selected product or a particular for of marketing.

In Norway the Market Council's practice in relation to the principle of conflicting laws has led to a certain adjustment of the imbalances which are also found in Norwegian marketing law as regards the supervision of compliance with the ban on misleading marketing. This principle means that the Consumer Ombudsman cannot give a particular field a lower priority on the grounds only that it belongs under special legislation and so is not subject to his supervision. If the case is of particular interest to consumers, it will therefore be considered by the Consumer Ombudsman.

In Norway the amount of fines is about 300,000-500,000 NOK, with supplementary fines of 100,000-150,000 NOK for the person(s) responsible with the marketing company.

In Finland a very large part of the marketing act has been transferred to the Consumer Ombudsman's supervision and is regulated by chapter 2, article 1 , of the consumer protection act. Where this is not the case, e.g. as regards supervision of the marketing of food, the relevant authorities (the Finnish Consumer Agency and the Finnish Food Safety Authority) work together in order that the experience and expertise of both authorities are 
used, and it is agreed in each individual case which authority considers the case. Apparently there is therefore a high degree of consistency in the supervision of marketing, and the level of fines shows no differences no matter what product is sold using misleading marketing. The level of fines is so that in the most recent cases a fine of 50,000 euro (300,000 FIM) has been imposed on the person responsible for the marketing.

Sweden has no such problems as Denmark when it comes to coordinating efforts against misleading marketing in relation to different products as all marketing supervision belongs under the Consumer Ombudsman, and therefore the intensity and amount of penalties will become uniform in the entire field.

The amounts of fines are to a large extent "standardised" and there are no differences as to what product has been marketed in an unlawful way. The amount of fines in more recent practice is around 400,000 SEK with deviations in concrete cases. There is an upward tendency for the amount of fines in particularly serious cases of misleading marketing, which is beneficial, and it should be noted that the amount of fines should not stagnate if marketing costs and intended profits increase.

\section{Conclusion:}

The simplest and apparently most effective organisation of the supervision of compliance with the ban on misleading marketing is probably found in the Swedish and Finnish models:

The Consumer Agency and the Consumer Ombudsman in Sweden, as mentioned above, carry out supervision in general in all fields covered by this report. The other authorities which carry out supervision of sales and marketing of special products must not supervise whether marketing is improper, untrustworthy or misleading and in contravention of the rules on good marketing practice of article 4 of the marketing act and article 6 of the ban on misleading marketing, and a very large part of the marketing in Finland belongs under the supervision of the Consumer Ombudsman and is regulated by chapter 2 , article 1 , of the consumer protection act. Where this is not the case, e.g. as regards supervision of the marketing of food, the relevant authorities (the Finnish Consumer Agency and the Finnish Food Safety Authority) work together in order that the experience and expertise of both authorities are used, and it is agreed in each individual case which authority considers the case. Apparently there is therefore a high degree of consistency in the supervision of marketing,

This gives a high degree of consistency in these countries' sanctioning of the ban on misleading marketing, and there are no differences in the level of fines for different types of products. 
As it will appear from the above, the need to amend legislation and/or change the practice relating to the enforcement of the ban on misleading marketing is different in the various countries.

The biggest need for change in this field is apparently seen in Denmark where it might be considered either to amend legislation in order that supervision of all marketing is transferred to the Consumer Ombudsman with the pros and cons this would entail or initiatives could be taken in making the relevant authorities work together on the enforcement of the ban on misleading marketing in special legislation (to a higher extent than what may be the case today).

This applies both to the intensity and amount of fines. It is however different how the supervision of marketing is carried out within each special legislation as the Danish Veterinary and Food Administration has already set up a control unit in the field of food supplements and the food regions have, successfully, run periodic campaigns to control the extent of misleading marketing within the different areas.

It is estimated that in Denmark there is neither a need for more rules of law nor more supervisory authorities, but there is a need to gather and coordinate efforts. There is also a need to provide sufficient resources for the relevant supervisory authorities to carry out these tasks as regulation without real control possibilities cannot be expected to function as intended. It should be noted that the possibilities of violation are strongly increasing as a result of new forms of marketing and sales in a rapidly developing market, including for instance the development of the Internet.

In Norway the legal situation is very similar to the Danish one, with special legislation and authorities with competing competencies, and supervision within the special fields is less intensive as compared to the marketing act - maybe almost non-existent. It has however to some extent been attempted to remedy this situation as the Consumer Ombudsman and the special authorities have entered into agreements which means that the Consumer Ombudsman takes on supervision for a period of time in specific fields. The practice of the Market Council has also meant that the Consumer Ombudsman considers cases which in principle belong under special legislation, but which are also a violation of the omnibus clause of the marketing act.

In Finland a very large part of the fields, which in this report are defined as special fields, have been transferred to the Consumer Ombudsman's direct supervision, which simplifies the problem somewhat. Apart from this the relevant authorities work actively together, which means that no imbalances occur neither in the supervision nor the level of fines.

Sweden has no such problems as Denmark when it comes to coordinating efforts against misleading marketing in relation to different products as all marketing supervision belongs under the Consumer Om- 
budsman, and therefore the intensity and amount of penalties will become uniform in the entire field.

Iceland has an administrative system where the authorities in the various municipalities carry out the supervision with the special fields. Where violations are found, the municipal authorities must ask the prosecution to institute criminal proceedings. This system is very heavy and demands considerable resources. The general supervision of marketing was changed as per 1 July 2005 after which a consumer authority has been set up which is to supervise the marketing. There is not yet any practice in the field, as the change is quite recent, but the material rules are widely the same in the new marketing act as in the old competition act. Practice after the previous legislation is made up of a rather small number of administrative cases and only one sentence, but the emerging picture of the level of fines is that the fines imposed are rather small (in the area of 20,000-50,000 DKK) which will hardly have a preventive effect in itself. 